Prepared in cooperation with the U.S. Agency for International Development

\title{
Managed Aquifer Recharge Suitability — Regional Screening and Case Studies in Jordan and Lebanon
}

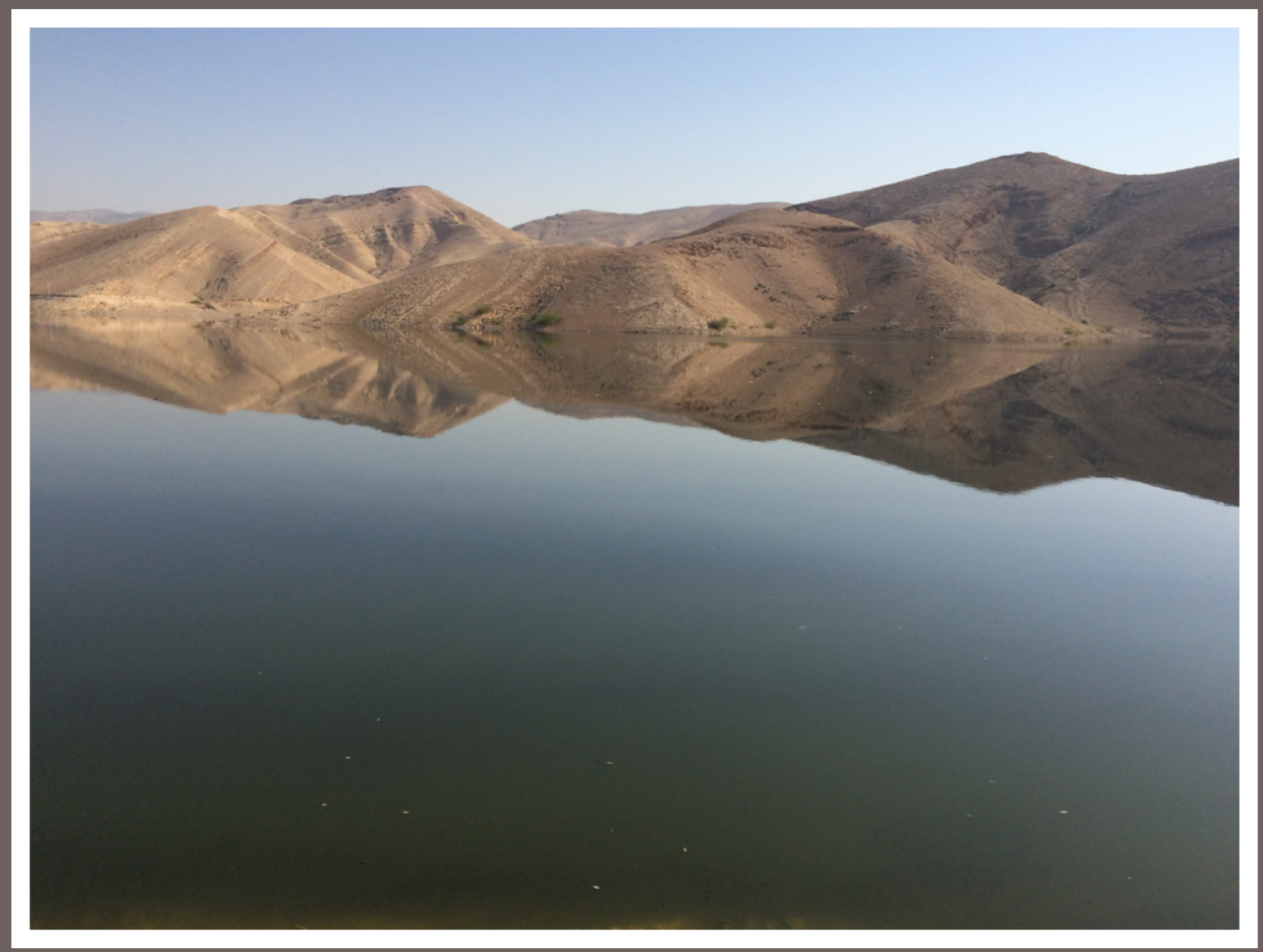

Open-File Report 2021-1089 
Cover. Kafrein reservoir captures runoff in the lower Jordan Valley, near the Dead Sea, Jordan. Photograph by Daniel J. Goode, U.S. Geological Survey, February 21, 2017. 


\section{Managed Aquifer Recharge Suitability- Regional Screening and Case Studies in Jordan and Lebanon}

Edited by Daniel J. Goode

Prepared in cooperation with the U.S. Agency for International Development

Open-File Report 2021-1089 


\section{U.S. Geological Survey, Reston, Virginia: 2021}

For more information on the USGS — the Federal source for science about the Earth, its natural and living resources, natural hazards, and the environment-visit https://www.usgs.gov or call 1-888-ASK-USGS.

For an overview of USGS information products, including maps, imagery, and publications, visit https://store.usgs.gov.

Any use of trade, firm, or product names is for descriptive purposes only and does not imply endorsement by the U.S. Government.

Although this information product, for the most part, is in the public domain, it also may contain copyrighted materials as noted in the text. Permission to reproduce copyrighted items must be secured from the copyright owner.

Suggested citation:

Goode, D.J., ed., 2021, Managed aquifer recharge suitability—Regional screening and case studies in Jordan and Lebanon: U.S. Geological Survey Open-File Report 2021-1089, 87 p., https://doi.org/10.3133/ofr20211089.

Associated data for this publication:

Kagone, S., Velpuri, N.M., and Senay, G.B., 2021, Assembly of satellite-based rainfall datasets in situ data and rainfall climatology contours for the MENA region: U.S. Geological Survey data release, https://doi.org/10.5066/P971ZVHF.

Senay, G.B., Kagone, S., Velpuri, N.M., and Goode, D.J., 2021, Modeling accumulated surface runoff and water availability for aquifer storage and recovery in the MENA region from 1984-2015: U.S. Geological Survey data release, https://doi.org/10.5066/P9TXLT1X.

ISSN 2331-1258 (online) 


\section{Acknowledgments}

The authors would like to thank contributors to this report and project, including Sonia Massis, Kamal Ouda, and John Wilson of the U.S. Agency for International Development;

Shehdeh Jodeh, Ghadir Hanbali, and Mohammed Hmidat of An-Najah National University; Deeb Abdulghafour, Salaam Abu Hantash, Omar Zayed, Alaa Masri, and Subhi Samhan of the Palestinian Water Authority; Thair Al-Momani and Ali Subah of the Ministry of Water and Irrigation, Jordan; and Fadi Doumit of the Litani River Authority, Lebanon. We also thank James Rowland and Saud Amer of the U.S. Geological Survey for their technical reviews. 



\section{Contents}

Acknowledgments ……...................................................................................................................

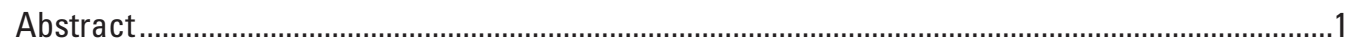

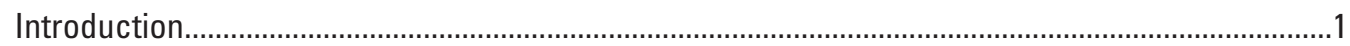

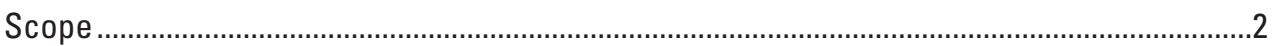

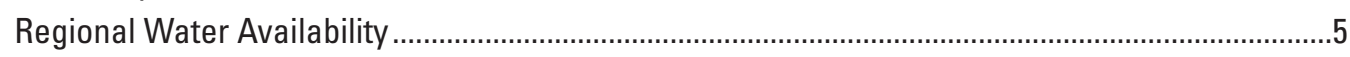

Precipitation and Land-Surface Characteristics.............................................................

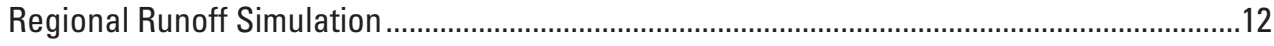

Runoff Comparison with Monitoring Data ........................................................................2

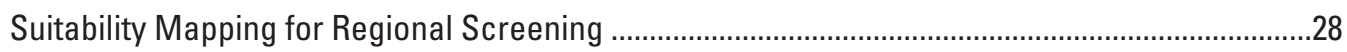

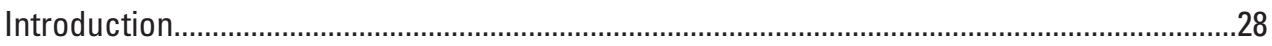

Classification and Combined Ranking Method …………........................................................30

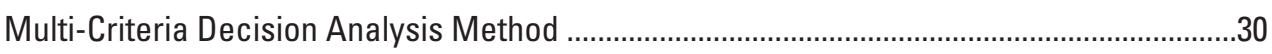

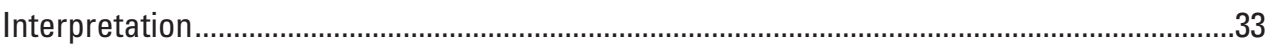

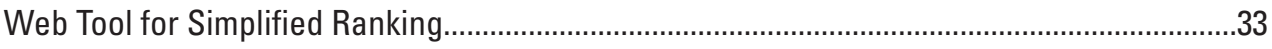

Jordan Case Study ..............................................................................................................

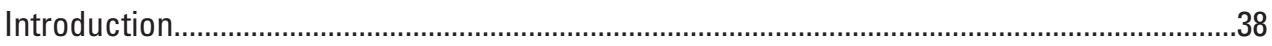

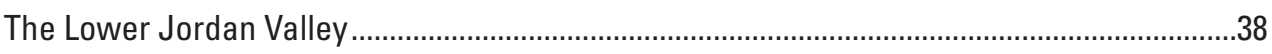

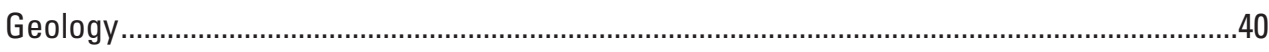

Ghor El Kattar and Shagure Conglomerates ..............................................................40

Abu Habil, Kufranja, and Samra Formations ...............................................................40

Lisan Formation ................................................................................................... 42

Recent Alluvial Fans ..................................................................................................

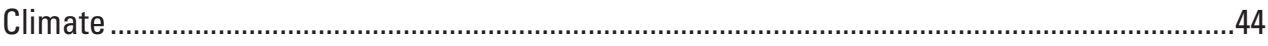

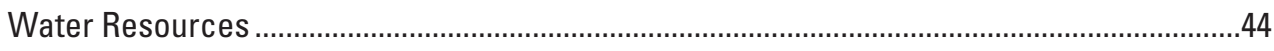

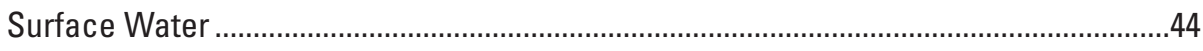

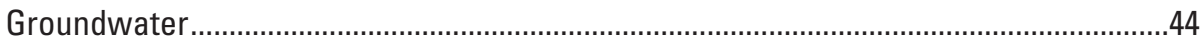

Suitability for Managed Aquifer Recharge .........................................................................

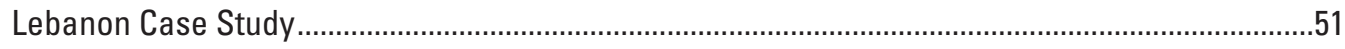

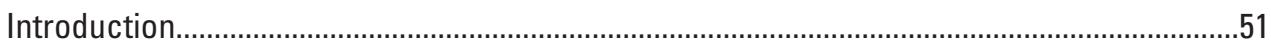

Geology

Hydrogeology

Multi-Criteria Decision Analysis ....................................................................................

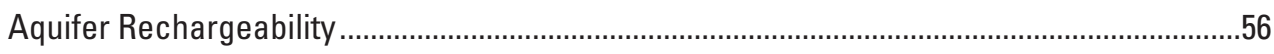

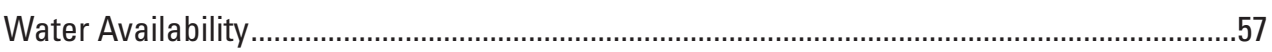

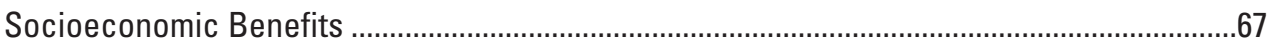

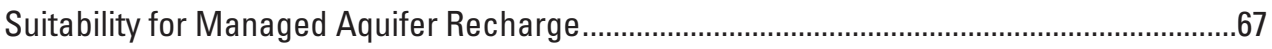

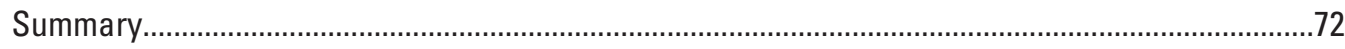

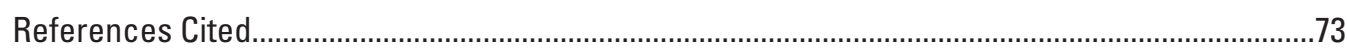

Appendix 1. Project Activities for Acceleration of Aquifer Storage and Recovery in the Middle

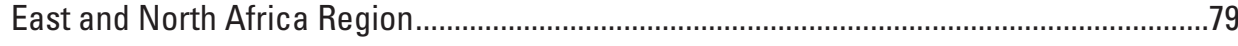

Appendix 2. Bedrock Geology of the Lower Jordan Valley, Jordan .............................................86 


\section{Figures}

1. Map showing location of the study area in an eastern part of the Middle East and

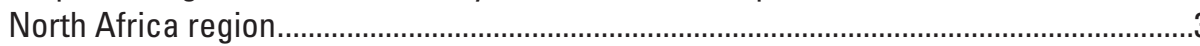

2. Schematic illustration of the Vegetation Evapotranspiration model ...................................

3. Map depicting elevation distribution in the modeled domain in Lebanon, Jordan, and surrounding areas.

4. Maps depicting precipitation estimated from remote sensing data for the modeled domain in Lebanon, Jordan, and surrounding areas.

5. Maps showing monthly average Normalized Difference Vegetation Index estimated from remote sensing data

6. Maps depicting monthly average land surface air temperature for the modeled domain in Lebanon, Jordan, and surrounding areas

7. Maps depicting monthly average reference evapotranspiration for the modeled domain in Lebanon, Jordan, and surrounding areas.

8. Graph showing example VegET daily model simulation

9. Maps showing actual evapotranspiration simulated for the modeled domain in Lebanon, Jordan, and surrounding areas

10. Maps depicting surface runoff simulated for the modeled domain in Lebanon, Jordan, and surrounding areas

11. Maps showing average annual accumulated surface runoff simulated in Lebanon, Jordan, and surrounding areas

12. Map depicting average annual accumulated surface runoff in streams simulated for the modeled domain in Lebanon, Jordan, and surrounding areas.

13. Map depicting the coefficient of variation of annual accumulated surface runoff simulated for the modeled domain in Lebanon, Jordan, and surrounding areas.

14. Map showing topography, streamflow measurement locations, and corresponding runoff model subbasins, lower Jordan Valley, Jordan

15. Graph showing simulated and measured streamflow at measurement locations in the lower Jordan Valley, Jordan.

16. Graph depicting simulated and measured runoff coefficient at streamflow measurement locations in the lower Jordan Valley, Jordan

17. Map showing the Damour River basin, Lebanon, with topography, streamflow measurement locations, and corresponding subbasins for the runoff model

18. Graph showing simulated and measured streamflow at measurement locations in the Damour River Basin, Lebanon .

19. Graph showing simulated and measured runoff coefficient at streamflow measurement locations in the Damour River Basin, Lebanon.

20. Diagram depicting an example of grouping of criteria used in evaluated geographic information system-multicriteria decision analysis studies

21. Map showing land surface slope in Lebanon, Jordan, and surrounding areas ..............31

22. Map showing regional screening suitability in Lebanon, Jordan, and surrounding areas based on slope and water availability only.....

23. Map depicting managed aquifer recharge suitability score in Lebanon, Jordan, and surrounding areas.

24. Conceptual diagram of the suitability map making process .............................................36

25. Screenshot of the web application. 
26. Flow chart depiciting general design and development stages for managed aquifer recharge.....

27. Map of study area in the lower Jordan Valley, Jordan, showing topography, hydrologic features, and numbered zones evaluated for managed aquifer recharge

28. Schematic diagram depicting an east-west cross section showing topography and surficial geology of the lower Jordan Valley, Jordan....

29. Map showing surface geology of the lower Jordan Valley and northwest Jordan........43

30. Map showing average annual precipitation depth estimated from remote sensing data in the lower Jordan Valley area, Jordan.

31. Map depicting average annual surface runoff depth simulated in the lower Jordan Valley area, Jordan

32. Map depicting average annual stream discharge from surface runoff simulated in the lower Jordan Valley area, Jordan

33. Map depicting managed aquifer recharge suitability .......................................................49

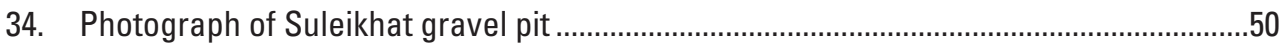

35. Map of the Damour River Basin in Lebanon, showing topography and locations of streamgages

36. Map showing surface geology of the Damour River Basin, Lebanon ..............................54

37. Schematic of Multi-Criteria Decision Analysis.................................................................56

38. Map depicting epikarst classification of the Damour River Basin, Lebanon ...................58

39. Map showing karst cover classification of the Damour River Basin, Lebanon ...............59

40. Map showing land surface slope classification of the Damour River Basin .................60

41. Map depicting aquifer rechargeability score of the Damour River Basin .......................61

42. Map showing average annual surface runoff simulated in the Damour River Basin .....62

43. Map depicting average annual accumulated surface runoff in streams simulated in the Damour River Basin, Lebanon

44. Map showing coefficient of variation of annual accumulated runoff in streams simulated in the Damour River Basin, Lebanon

45. Graphs showing linear score functions for water availability second-level factors $A$, volume, and $B$, reliability

46. Map showing water availability score for Damour River Basin, Lebanon ......................66

47. Map depicting aquifer stress in the Damour River Basin ...............................................68

48. Map showing land use of the Damour River Basin..........................................................69

49. Map showing socioeconomic benefit score of the Damour River Basin ........................70

50. Map depicting managed aquifer suitability of the Damour River Basin ..........................71 


\section{Tables}

1. Streamflow measuring locations used for model calibration, lower Jordan Valley,

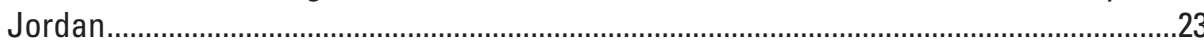

2. Streamflow monitoring stations in the Damour River Basin, Lebanon, used for runoff model comparison

3. Classes and ranking used to produce a managed aquifer recharge suitability map on the basis of slope and accumulated runoff

4. Multi-Criteria Decision Analysis used to produce a managed aquifer recharge suitability map

5. Critical factors in designing and implementing managed aquifer recharge in Jordan

6. Surficial formations in the Jordan Valley area

7. Average annual predevelopment stream discharge of major streams and intercatchment areas between major streams in the lower Jordan Valley, Jordan.......46

8. Estimated local surface runoff downstream of existing dams in the lower Jordan Valley, Jordan

9. Summary of managed aquifer recharge suitability ranking for zones along the foothills of the eastern lower Jordan Valley, Jordan. .50

10. Surface geology of the Damour River Basin, Lebanon .................................................55

11. Second-level factors, classifications, and scores for aquifer rechargeability................57

12. Streamgages and flow measurement points in the Damour River Basin .........................65

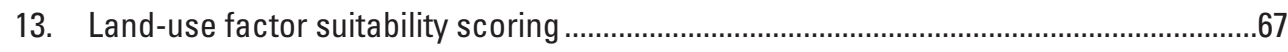




\section{Conversion Factors}

International System of Units to U.S. customary units

\begin{tabular}{|c|c|c|}
\hline Multiply & By & To obtain \\
\hline \multicolumn{3}{|c|}{ Length } \\
\hline centimeter $(\mathrm{cm})$ & 0.3937 & inch (in.) \\
\hline millimeter (mm) & 0.03937 & inch (in.) \\
\hline meter $(\mathrm{m})$ & 3.281 & foot $(\mathrm{ft})$ \\
\hline kilometer (km) & 0.6214 & mile (mi) \\
\hline \multicolumn{3}{|c|}{ Area } \\
\hline hectare (ha) & 2.471 & acre \\
\hline square kilometer $\left(\mathrm{km}^{2}\right)$ & 247.1 & acre \\
\hline square meter $\left(\mathrm{m}^{2}\right)$ & 10.76 & square foot $\left(\mathrm{ft}^{2}\right)$ \\
\hline square kilometer $\left(\mathrm{km}^{2}\right)$ & 0.3861 & square mile $\left(\mathrm{mi}^{2}\right)$ \\
\hline \multicolumn{3}{|c|}{ Volume } \\
\hline liter $(\mathrm{L})$ & 33.81402 & ounce, fluid (fl. oz) \\
\hline liter $(\mathrm{L})$ & 0.2642 & gallon (gal) \\
\hline cubic meter $\left(\mathrm{m}^{3}\right)$ & 264.2 & gallon (gal) \\
\hline cubic centimeter $\left(\mathrm{cm}^{3}\right)$ & 0.06102 & cubic inch $\left(\mathrm{in}^{3}\right)$ \\
\hline liter $(\mathrm{L})$ & 61.02 & cubic inch $\left(\mathrm{in}^{3}\right)$ \\
\hline cubic meter $\left(\mathrm{m}^{3}\right)$ & 35.31 & cubic foot $\left(\mathrm{ft}^{3}\right)$ \\
\hline cubic kilometer $\left(\mathrm{km}^{3}\right)$ & 0.2399 & cubic mile $\left(\mathrm{mi}^{3}\right)$ \\
\hline cubic meter $\left(\mathrm{m}^{3}\right)$ & 0.0008107 & acre-foot (acre-ft) \\
\hline \multicolumn{3}{|c|}{ Flow rate } \\
\hline cubic meter per year $\left(\mathrm{m}^{3} / \mathrm{yr}\right)$ & 0.000811 & acre-foot per year (acre-ft/yr) \\
\hline meter per second (m/s) & 3.281 & foot per second (ft/s) \\
\hline cubic meter per second $\left(\mathrm{m}^{3} / \mathrm{s}\right)$ & 35.31 & cubic foot per second $\left(\mathrm{ft}^{3} / \mathrm{s}\right)$ \\
\hline $\begin{array}{l}\text { cubic meter per second per } \\
\text { square kilometer }\left(\left[\mathrm{m}^{3} / \mathrm{s}\right] / \mathrm{km} 2\right)\end{array}$ & 91.49 & $\begin{array}{l}\text { cubic foot per second per square } \\
\text { mile }\left(\left[\mathrm{ft}^{3} / \mathrm{s}\right] / \mathrm{mi}^{2}\right)\end{array}$ \\
\hline cubic meter per day $\left(\mathrm{m}^{3} / \mathrm{d}\right)$ & 35.31 & cubic foot per day $\left(\mathrm{ft}^{3} / \mathrm{d}\right)$ \\
\hline liter per second $(\mathrm{L} / \mathrm{s})$ & 15.85 & gallon per minute (gal/min) \\
\hline cubic meter per day $\left(\mathrm{m}^{3} / \mathrm{d}\right)$ & 264.2 & gallon per day (gal/d) \\
\hline meter per hour $(\mathrm{m} / \mathrm{h})$ & 39.37 & inch per hour (in/h) \\
\hline millimeter per year (mm/yr) & 0.03937 & inch per year (in/yr) \\
\hline kilometer per hour $(\mathrm{km} / \mathrm{h})$ & 0.6214 & mile per hour $(\mathrm{mi} / \mathrm{h})$ \\
\hline \multicolumn{3}{|c|}{ Mass } \\
\hline gram $(\mathrm{g})$ & 0.03527 & ounce, avoirdupois (oz) \\
\hline kilogram $(\mathrm{kg})$ & 2.205 & pound avoirdupois (lb) \\
\hline \multicolumn{3}{|c|}{ Hydraulic conductivity } \\
\hline meter per day $(\mathrm{m} / \mathrm{d})$ & 3.281 & foot per day (ft/d) \\
\hline \multicolumn{3}{|c|}{ Transmissivity } \\
\hline meter squared per day $\left(\mathrm{m}^{2} / \mathrm{d}\right)$ & 10.76 & foot squared per day $\left(\mathrm{ft}^{2} / \mathrm{d}\right)$ \\
\hline
\end{tabular}


Temperature in degrees Celsius $\left({ }^{\circ} \mathrm{C}\right)$ may be converted to degrees Fahrenheit $\left({ }^{\circ} \mathrm{F}\right)$ as follows:

$$
{ }^{\circ} \mathrm{F}=\left(1.8 \times{ }^{\circ} \mathrm{C}\right)+32 .
$$

Temperature in degrees Fahrenheit $\left({ }^{\circ} \mathrm{F}\right)$ may be converted to degrees Celsius $\left({ }^{\circ} \mathrm{C}\right)$ as follows:

$$
{ }^{\circ} \mathrm{C}=\left({ }^{\circ} \mathrm{F}-32\right) / 1.8 \text {. }
$$

\section{Datum}

Vertical and horizontal coordinate information is referenced to the World Geodetic System of 1984 (vertical D_WGS_84; horizontal GCS_WGS_84).

Elevation, as used in this report, refers to distance above the vertical datum.

\section{Supplemental Information}

Specific conductance is given in microsiemens per centimeter at 25 degrees Celsius $(\mu \mathrm{S} / \mathrm{cm}$ at $\left.25^{\circ} \mathrm{C}\right)$. Electrical conductivity is given in microsiemens per centimeter $(\mu \mathrm{S} / \mathrm{cm})$.

Concentrations of chemical constituents in water are given in milligrams per liter (mg/L).

\section{Abbreviations}

$\begin{array}{ll}\text { AHP } & \text { Analytic Hierarchy Process } \\ \text { AUB } & \text { American University of Beirut } \\ \text { ANU } & \text { An-Najah National University } \\ \text { ASR } & \text { aquifer storage and recovery } \\ \text { CV } & \text { coefficient of variation } \\ \text { DEM } & \text { digital elevation model } \\ \text { EPA } & \text { U.S. Environmental Protection Agency } \\ \text { ET } & \text { evapotranspiration } \\ \text { ETa } & \text { actual evapotranspiration } \\ \text { ETo } & \text { reference evapotranspiration } \\ \text { GIS } & \text { geographic information system } \\ \text { LRA } & \text { Litani River Authority } \\ \text { MAR } & \text { managed aquifer recharge } \\ \text { MCDA } & \text { Multi-Criteria Decision Analysis } \\ \text { MENA } & \text { Middle East and North Africa } \\ \text { NCRD } & \text { National Center for Research and Development } \\ \text { NDVI } & \text { Normalized Difference Vegetation Index }\end{array}$


ppm parts per million

SRF surface runoff

SW soil water

SWE snow water equivalent

USAID U.S. Agency for International Development

USGS U.S. Geological Survey

VegET vegetation evapotranspiration

WWTP wastewater treatment plant 



\title{
Managed Aquifer Recharge Suitability-Regional Screening and Case Studies in Jordan and Lebanon
}

\author{
Edited by Daniel J. Goode ${ }^{1}$
}

\section{Abstract}

The U.S. Geological Survey, at the request of the U.S. Agency for International Development, led a 5-year regional project to develop and apply methods for water availability and suitability mapping for managed aquifer recharge (MAR) in the Middle East and North Africa region. A regional model of surface runoff for the period from 1984 to 2015 was developed to characterize water availability using remote sensing data on climate, vegetation, and topography in Jordan, Lebanon, and surrounding areas. Surface runoff was accumulated to characterize potential streamflow available for MAR and these data were combined with land surface slope to prepare a regional screening map of MAR suitability, illustrating suitability mapping concepts and methods. The application of the methods is demonstrated by the evaluation of water availability and suitability for potential MAR in study areas in Jordan and Lebanon. Locations suitable for MAR are present in both Jordan and Lebanon, but limitations exist in both countries, related primarily to water availability in Jordan and land areas of suitable terrain in Lebanon. An additional feasibility study including field investigations would likely provide decision makers with essential information for further development of the use of MAR in Jordan, Lebanon, and the region.

\section{Introduction}

\section{By Jack R. Eggleston', Michael van der Valk², and Daniel J. Goode ${ }^{1}$}

The water supply issues in Jordan and Lebanon reflect those faced by many other countries in the Middle East and North Africa (MENA) region. In some coastal and highland areas, the climate is considered to be Mediterranean or

\footnotetext{
${ }^{1}$ U.S. Geological Survey.

${ }^{2}$ Hydrology.NL.
}

semiarid, with hot, dry summers and wet, mild winters. Other parts of the region are desert, with an arid climate that results in little to no groundwater recharge or perennial surface water flow. Population growth, economic development, and regional migration, in particular, have led to increased water demand, which in turn has exhausted most available surface waters and resulted in unsustainable use of groundwater resources. Water quality in groundwater has also been impaired by infiltration of incompletely treated wastewater, evaporative salinization, and declining water levels in coastal aquifers, leading to seawater intrusion. Declining groundwater levels in aquifers used for water supply have also caused increasing groundwater salinity in regional discharge areas (Goode and others, 2013).

Although Lebanon has, on average, much more precipitation than Jordan, there are several areas where groundwater depletion has contributed to reduced water quality, including seawater intrusion in coastal Beirut (Khair and others, 1994; Momejian and others, 2019) In addition, surface water resources have been contaminated by agricultural runoff or direct discharge of incompletely treated wastewaters in both Lebanon (Itani and others, 2021) and Jordan (Abdallat and others, 2020)

The capture of flood waters and wadi (stream) runoff for storage in aquifers has a long history both in the MENA region and globally (Todd, 1959; Aiken and Kuniansky, 2002; Weeks, 2003; Abdo and Eldaw, 2006; Dillon and others, 2019). In the early 2000s, a new appraisal made more people aware of these methodologies (Gale, 2005; Van Steenbergen, 2009). The practice of capturing storm runoff or treated wastewater for recharge and later use is known as rainwater harvesting, artificial recharge, aquifer storage and recovery (ASR, often using injection and withdrawal wells), or, in general, managed aquifer recharge (MAR). MAR is a collection of methods for capturing water and storing it underground so that it can later be used for water supply, or to ameliorate other water resource issues such as seawater intrusion into coastal aquifers.

One of the most common MAR methods is the construction of barriers in a riverbed that hold back the water and sediment, which reduces peak flow, thereby both reducing the flood risk and enhancing the amount of water recharged to the aquifer. This method - also known as the spreading method (Gale, 2005) as it spreads out the water over a larger area (and 
time) - has been used for at least two millennia. As early as the first century C.E., the Nabataea people in Petra, Jordan, built dams in wadis upstream of the city (Urban and others, 2013), in successful attempts to prevent the city from being flooded owing to erratic rainfall events while simultaneously recharging the aquifer for water usage during dry periods:

"Storage dams across the numerous wadis intersecting the urban core served to reduce floodwater entry into the city while seepage from the impoundments recharged the water table allowing for wells during protracted drought" (Ortloff, 2005).

In fact, the world's oldest known dams have been found in Northern Jordan, with carbon-14 dating indicating initial construction shortly after about 4,500 years before present (B.P.) (Helms, 1981; Viollet, 2000). Also, Dottridge (1998) points at several systems in the Jordanian Badia (arid flatlands), including "artificial recharge of the upper aquifer," the largest of which "is at a farm on Wadi Gharbi, to the northwest of Azraq, where the wadi flows are captured by a small dam and pumped into a deep storage reservoir" (Dutton and others, 1998).

Although the potential value of MAR in the MENA region is recognized (Zaki and others, 2006), its use has been limited by difficulties identifying and characterizing suitable sites (Edworthy, 2001) and by challenges in matching appropriate technology to site conditions (Maliva, 2011; Steinel and others, 2012). Based on a literature study, Van Lidth de Jeude (2016) found that, "even though most studies are focused on arid and semiarid climates, only a small part of the MAR projects are in those climates." Although the highest need for MAR is in arid and semiarid regions globally, only a small number of MAR projects are situated in semiarid regions. MAR projects can have high site characterization costs and limited benefit when MAR design is not well matched to cultural and hydrogeologic conditions (de Laat and Nonner, 2012; Steinel and others, 2012).

Storm runoff in the MENA region that currently flows unused to the sea or to saline basins can be captured using MAR and stored in aquifers for later use. With adequate treatment, wastewater can also be recharged to aquifers for storage and subsequent reuse (National Research Council, 1994; CDM Smith Inc., 2012; Beak and others, 2020). MAR can be implemented at small scales by farmers and others using locally sourced materials, or at large scales by utilities or government agencies (Thornton, 2001).

MAR is currently underutilized in the MENA region owing to the difficulties in identifying and assessing suitable sites. These difficulties include the lack of data needed to characterize the amount of water available for potential recharge, and the suitability of site conditions for selected MAR methods. New methods to map and identify high potential MAR locations using remote sensing and other geospatial and ancillary data, and hydrologic analysis can provide information needed to support the expansion of MAR in the MENA region to improve water security.

\section{Scope}

The U.S. Geological Survey (USGS), at the request of the U.S. Agency for International Development (USAID), led a 5-year project to develop and apply methods for water availability and suitability mapping for artificial recharge in the Middle East and North Africa region. The project concept was formulated at a water security workshop organized and hosted by USAID in 2015. Workshop organizers facilitated the formation of partnerships between diverse stakeholders and researchers, and ultimately initiated regional collaborative projects, including the one responsible for this report. The project team, led by USGS, included the American University of Beirut, the National Center for Research and Development (Jordan), the Arab Water Council (Cairo, Egypt), and Hydrolgy.NL (The Netherlands). More details about the project activities and participants are in appendix 1 .

Regional analysis methods for water availability and MAR suitability were developed using publicly available geospatial datasets and limited site-specific monitoring data and evaluations. Application of the methods was demonstrated by the development of regional water availability and suitability datasets, as an illustrative screening method, and by evaluation of water availability and MAR suitability in parts of Jordan and Lebanon (fig. 1). 


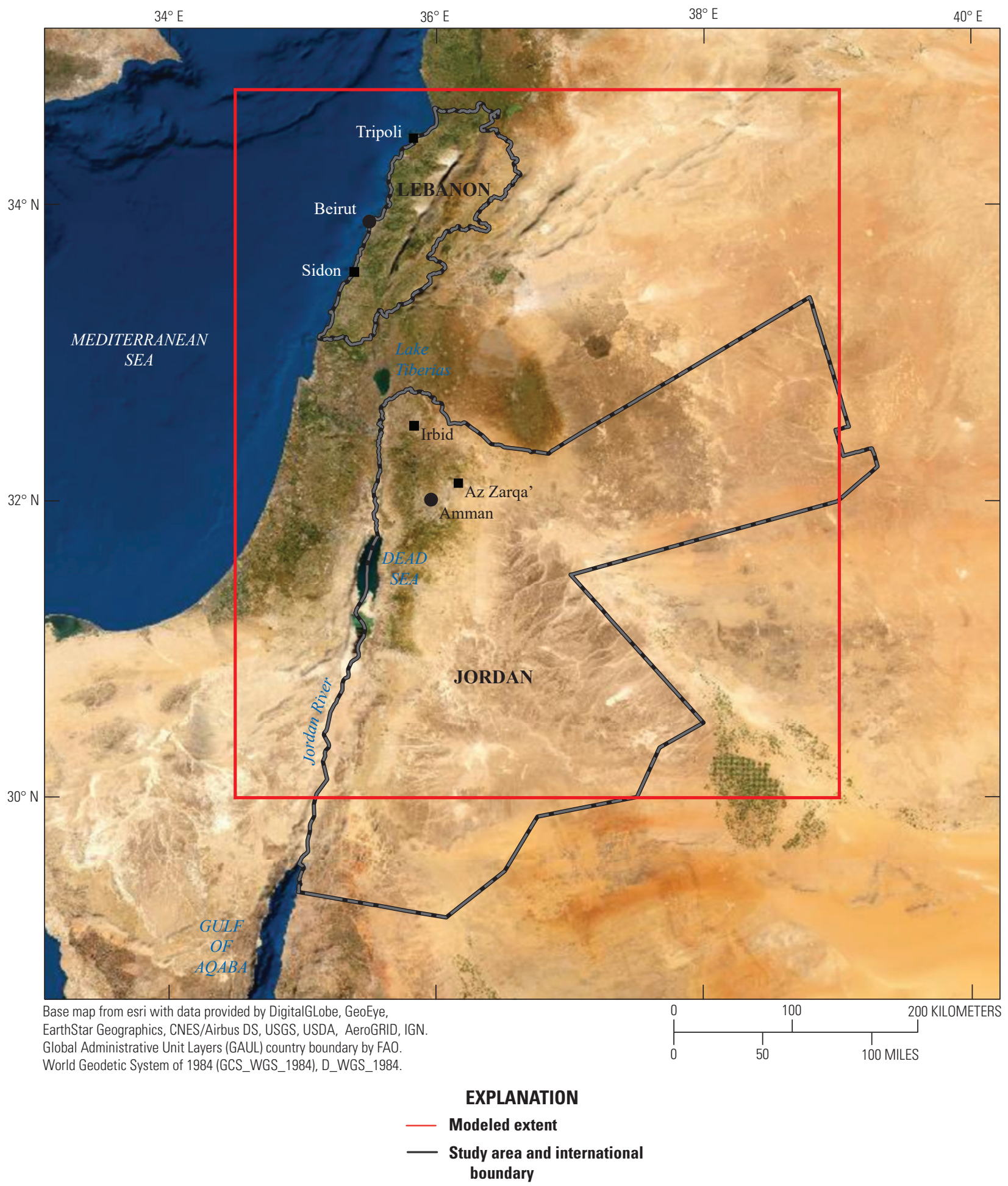

Figure 1. Location of the study area in an eastern part of the Middle East and North Africa region including the case study area countries of Jordan and Lebanon and surrounding areas. 
VEG ET MODEL SET UP

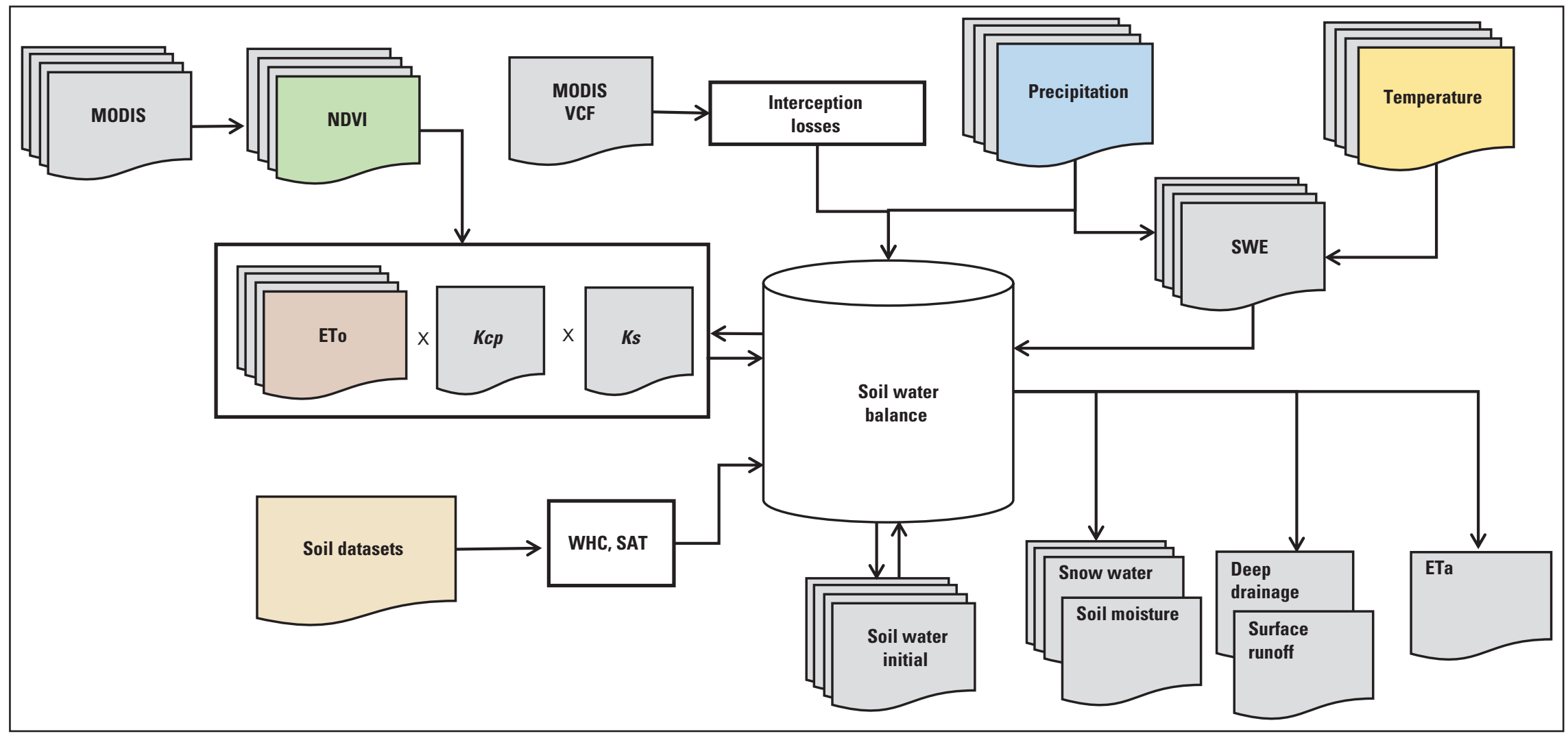

Figure 2. Schematic illustration of the Vegetation Evapotranspiration (VegET) model by Senay (2008). The major inputs are precipitation, reference evapotranspiration (ETo), temperature, Normalized Difference Vegetation Index (NDVI) and raster datasets to determine soil characteristics. The main outputs are soil moisture, actual evapotranspiration (ETa), and runoff. MODIS, Moderate Resolution Imaging Spectroradiometer; VCF, Vegetation Continuous Fields; SWE, snow water equivalent; Kcp, crop coefficient; Ks, soil water stress factor; WHC, water-holding capacity; SAT, saturation. 


\section{Regional Water Availability}

\author{
By Stefanie Kagone ${ }^{1}$, Naga Manohar Velpuri ${ }^{1,2}$, \\ Gabriel B. Senay ${ }^{3}$, and Daniel J. Goode ${ }^{3}$
}

A model for surface runoff was developed for part of the MENA region (model domain shown by red-outline area in fig. 1) to estimate the availability of excess runoff that could be captured and used for MAR. A satellite precipitation dataset for the model domain at 500-meter (m) spatial resolution was prepared from publicly available data for the period 19842015 (Kagone and others, 2021). The Vegetation Evapotranspiration (VegET) model was chosen to generate evapotranspiration (ET) and surface runoff (SRF) simulations from 1984 to 2015. It is a root-zone water balance model, developed by Senay (2008), and integrates water balance algorithms with the land surface phenology from remotely sensed Normalized Difference Vegetation Index (NDVI) to conduct root-zone water balance modeling of mainly rainfall driven systems at the using readily available global datasets. The model schematics are illustrated in figure 2.

\section{Precipitation and Land-Surface Characteristics}

Precipitation varies spatially within the model domain in the case study countries of Jordan and Lebanon and surrounding areas in relation to the variation of land surface elevation (fig. 3). The Lebanon Mountains have peaks as high as about 3,000-m, where rain is plentiful and snow accumulates in winter; snowmelt and rainfall move both into underlying karst aquifers and into streams that drain to the Mediterranean Sea. In contrast, Jordan has a valley running along its western border that reaches depths of more than 400-m below sea level and is bordered by rift valley escarpments on east and west. Precipitation in the highlands, mostly winter rains, drains via streams and aquifers into the valley and ultimately to the Jordan River and Dead Sea.

The daily precipitation raster data used in the model were created based on the raster dataset Multi-Source WeightedEnsemble Precipitation (MSWEP) version 1 (Beck and others, 2017) and in situ precipitation data. The raster data was disaggregated from its native spatial resolution of 25 kilometers $(\mathrm{km})$ to $5 \mathrm{~km}$ using the Climate Hazards Group InfraRed Precipitation with Station raster (CHIRPS) dataset. The precipitation data was then downscaled to 500-m resolution and bias corrected based on measurements at rain gages. The average

${ }^{1}$ ASRC Federal Data Solutions.

${ }^{2}$ International Water Management Institute.

${ }^{3}$ U.S. Geological Survey. monthly precipitation amount and the annual precipitation over time is shown in figure 4. The annual pattern in Lebanon reveals that most precipitation is received from October to April, with the greatest amount from December to February. This provides snow in the Lebanese mountains, which is later received as snowmelt in the spring and contributes to runoff. Jordan receives the largest amount of rainfall in the northwest, in highlands adjacent to the Jordan Valley, and modest amounts throughout the rest of the country. The lowest annual precipitation in the area shown was in 1985 and the highest in 1994.

The other major model input dataset is NDVI. The data was acquired from Didan (2015) and a median daily raster dataset for the period 2001-15 at spatial resolution of $500 \mathrm{~m}$ was created using linear interpolation. This smoothed dataset has a spatial scale larger than typical farms, but was considered to provide adequate accuracy for suitability mapping at the model scale. This provided a dataset including 366 days where each pixel presents the phenology of the vegetation at a given location over the course of an average year. The monthly distribution of the vegetation index throughout the study region is shown in figure 5; with most precipitation occurring in the cold season, a greening of the landscape is observed especially from February to April.

To determine whether precipitation fell as rain or snow we use average daily air temperature from WorldClim (Fick and Hijmans, 2017). The data have a spatial resolution of 30 seconds of latitude and longitude $\left(\sim 1 \mathrm{~km}^{2}\right)$ and were averaged monthly for the period 1970-2000. The data were downscaled from a monthly to a daily time step using linear interpolation. This provided a dataset of 366 days where each pixel represents the interpolated daily temperature at a given location over the course of an average year. The monthly average air temperature across the region, which follows the Mediterranean climate of a mild winter from December to March and a hot summer from May to September, is shown in figure 6.

The daily reference evapotranspiration (ETo) dataset was acquired from the USGS Famine Early Warning System Network Data Portal (U.S. Geological Survey, 2021), calculated from National Oceanic and Atmospheric Administration's Global Data Assimilation System reference weather data using the Food and Agriculture Organization Penman-Monteith Method (Allen and others, 1998; Senay and others, 2008) at 1-km resolution. The 15-year average daily ETo for 2003-17 was used in the model for each year during the simulation period of 1984 to 2015. This provided a dataset including 366 days where each 500-m pixel represents the daily ETo at a given location over the course of an average year. The long-term daily average ETo was chosen to minimize random errors from the yearly dataset for this study, where the focus is mainly runoff generation, which is primarily driven by precipitation. The monthly ETo pattern throughout the year is comparable to air temperature, in other words, lower in the cold season and higher in the warm season (fig. 7). Overall, the spatial distribution is more homogenous than air temperature because it is mostly driven by available solar radiation. 


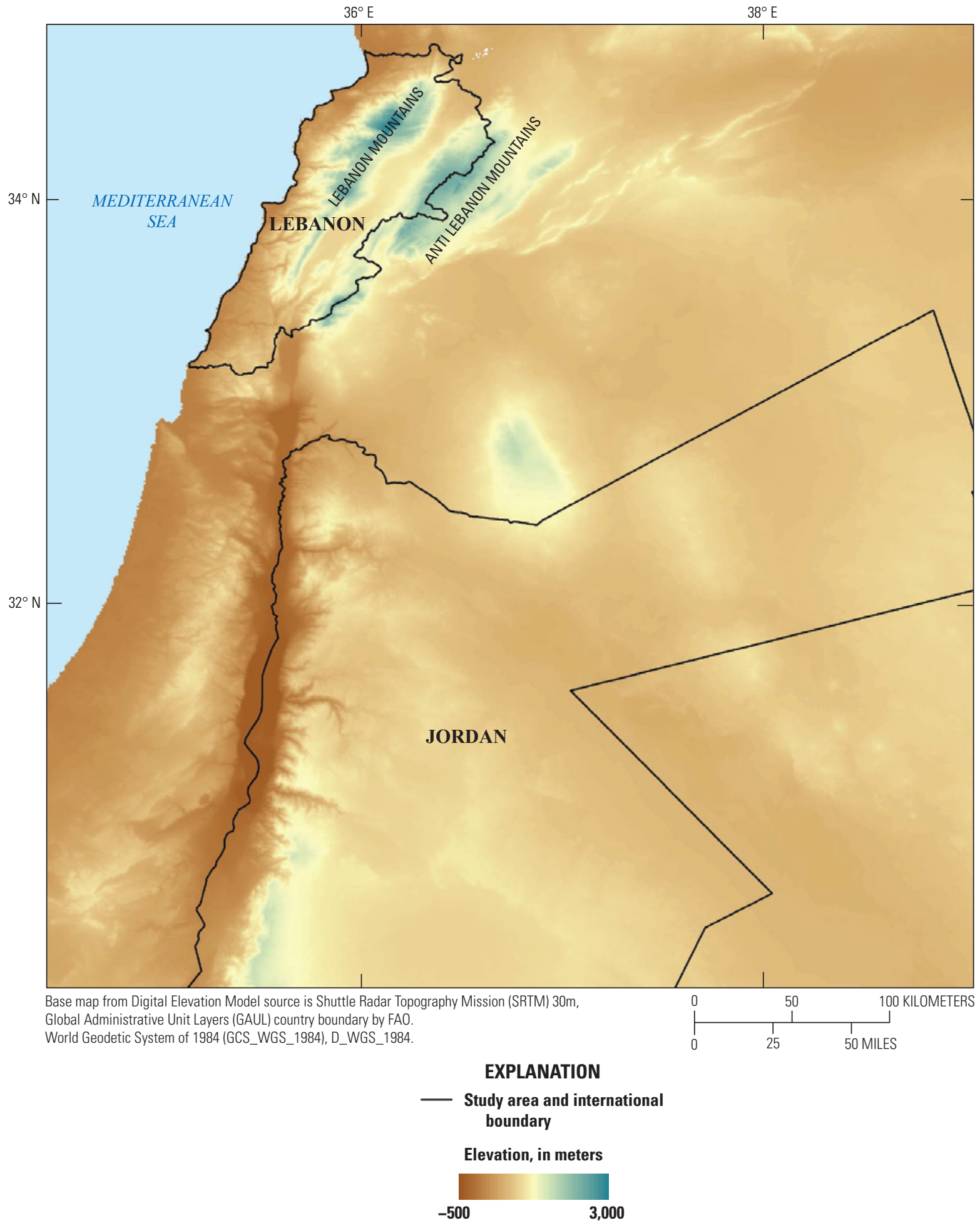

Figure 3. Elevation distribution in the modeled domain in Lebanon, Jordan, and surrounding areas. 


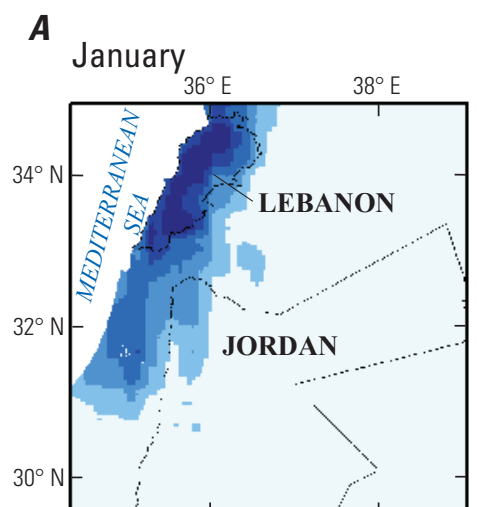

February

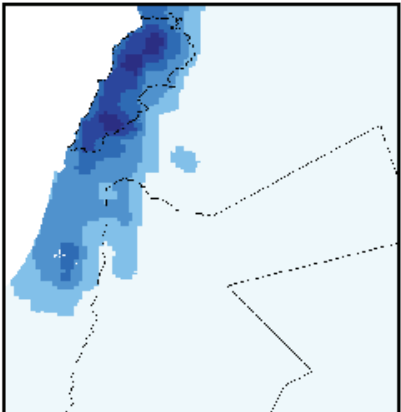

April

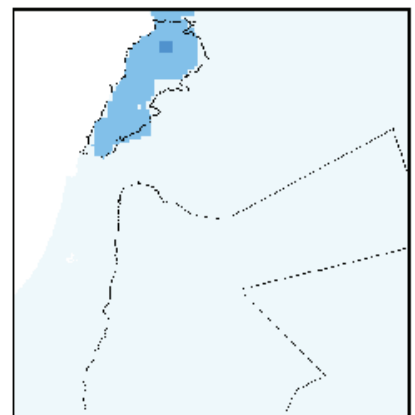

July

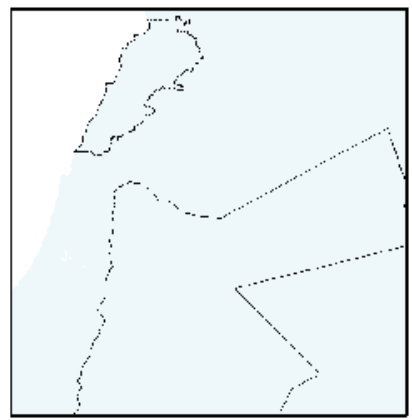

October

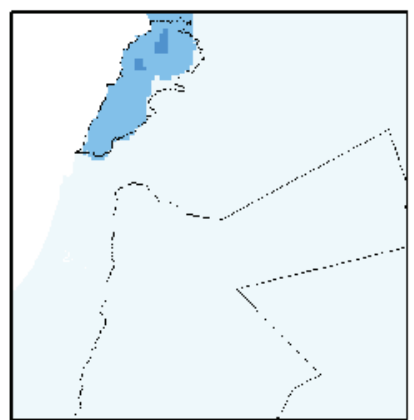

Base from Geodetic System of 1984 (GCS_WGS_1984)

\section{May}

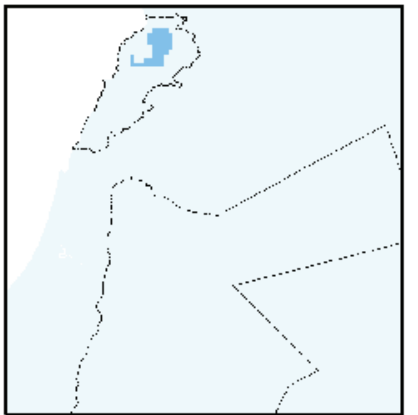

August

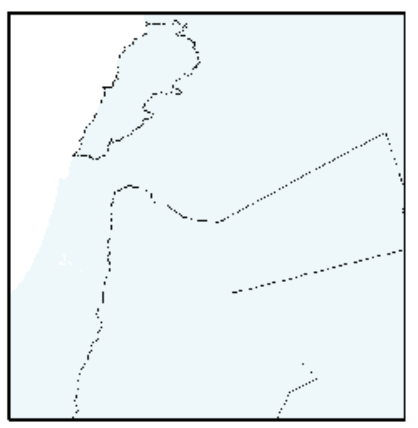

November

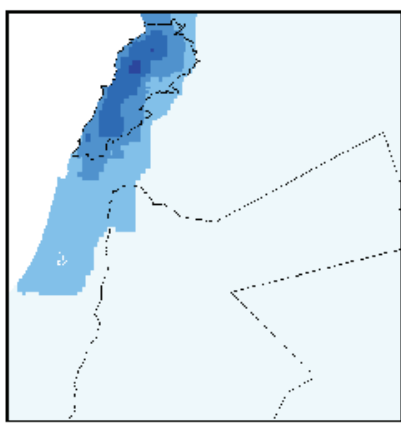

EXPLANATION
March

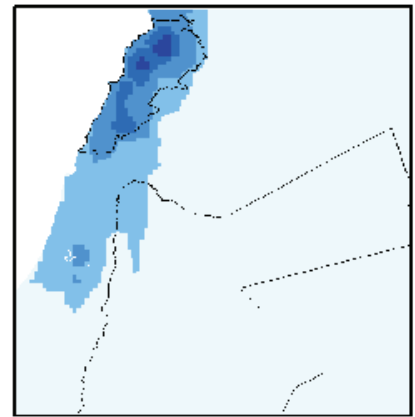

June

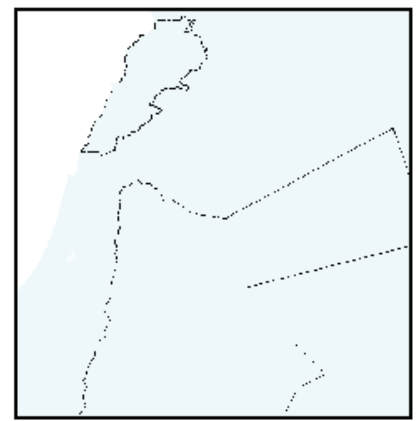

September

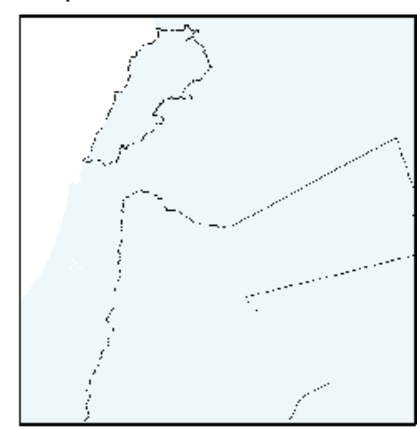

December

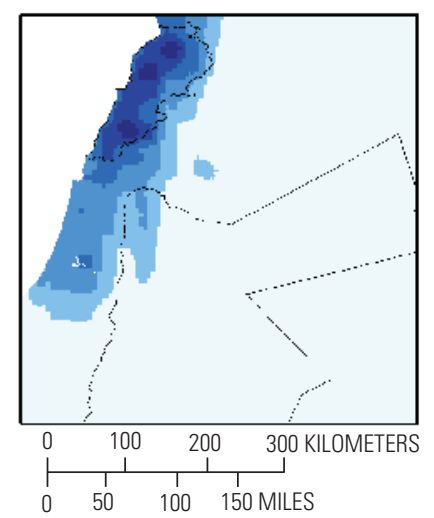

Precipitation, in millimeters

$\begin{array}{lllllll}0 & 50 & 100 & 200 & 250 & 300 & 350\end{array}$

Figure 4. Precipitation estimated from remote sensing data for the modeled domain in Lebanon, Jordan, and surrounding areas, from the 1984-2015 dataset (Kagone and others, 2021): $A$, Average monthly precipitation, and $B$, Annual precipitation for selected years and the period average annual precipitation. 


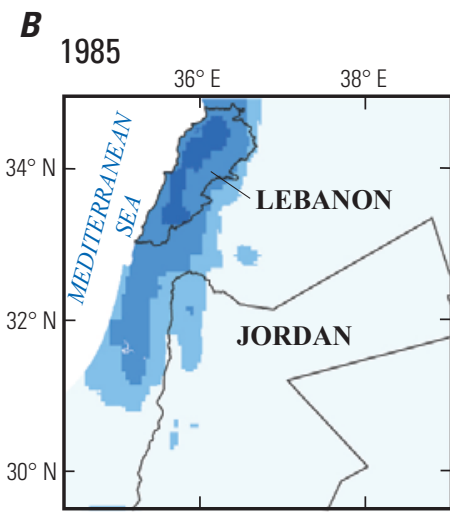

1988

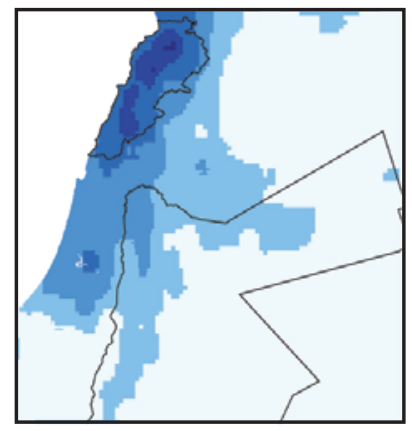

1997

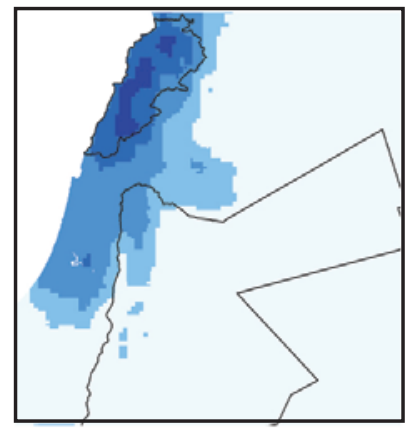

2009

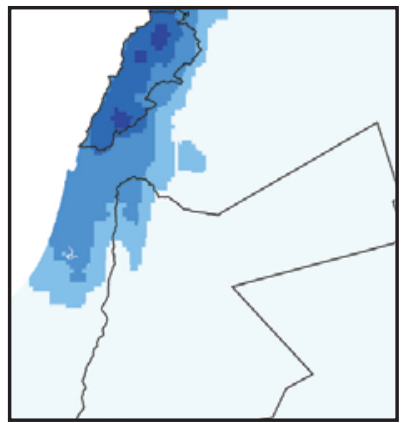

Base from Geodetic System of 1984 (GCS_WGS_1984)
2000

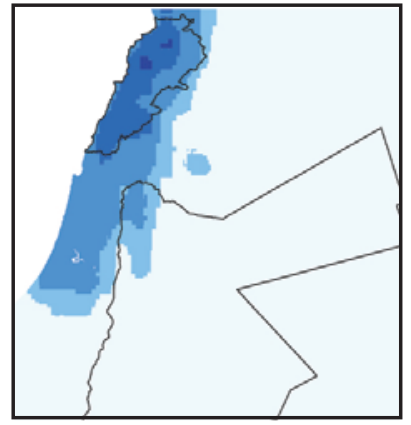

2012

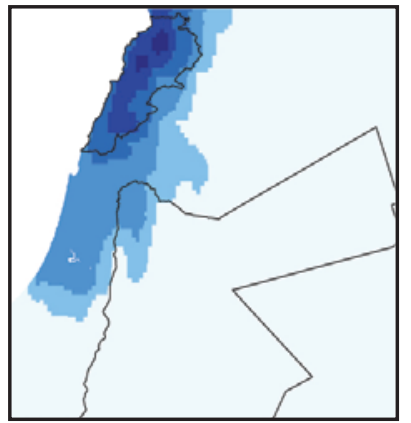

EXPLANATION

cipitation, in millimeters

$0 \quad 2505001,0001,5002,0002,500$

2003

2015
1991
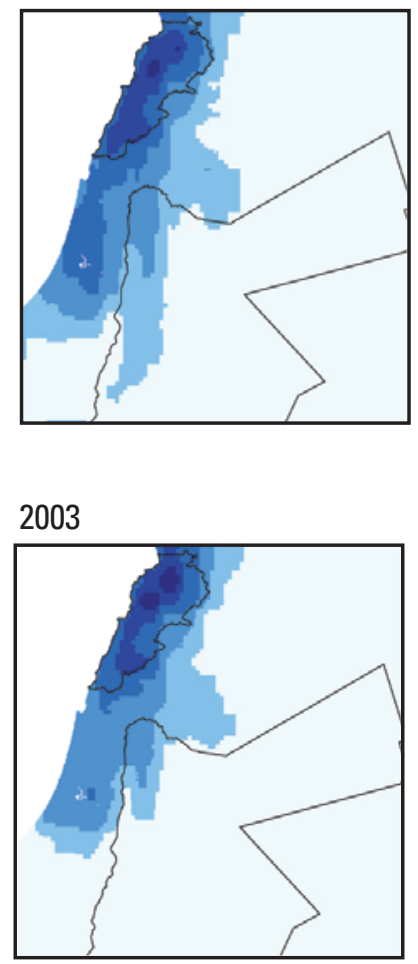

2006
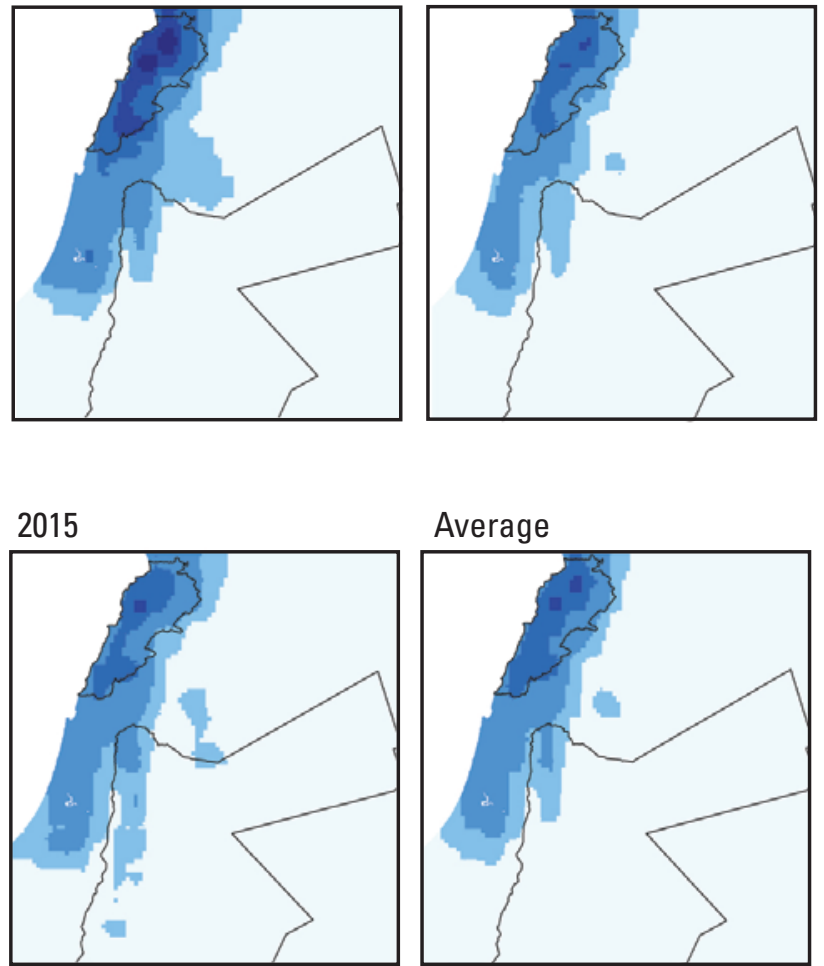

Average

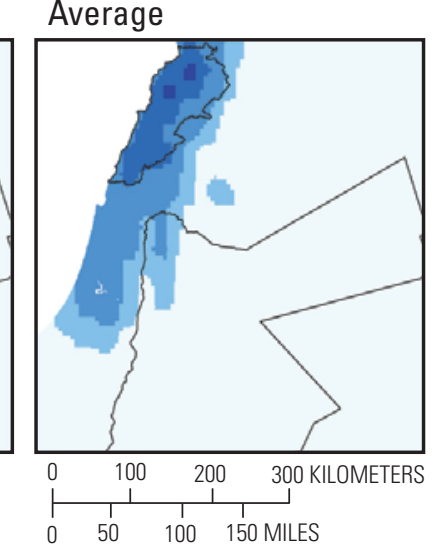

1994

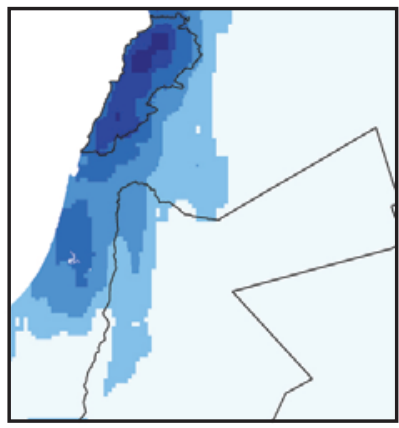

Figure 4. Precipitation estimated from remote sensing data for the modeled domain in Lebanon, Jordan, and surrounding areas, from the 1984-2015 dataset (Kagone and others, 2021): $A$, Average monthly precipitation, and $B$, Annual precipitation for selected years and the period average annual precipitation.-Continued 

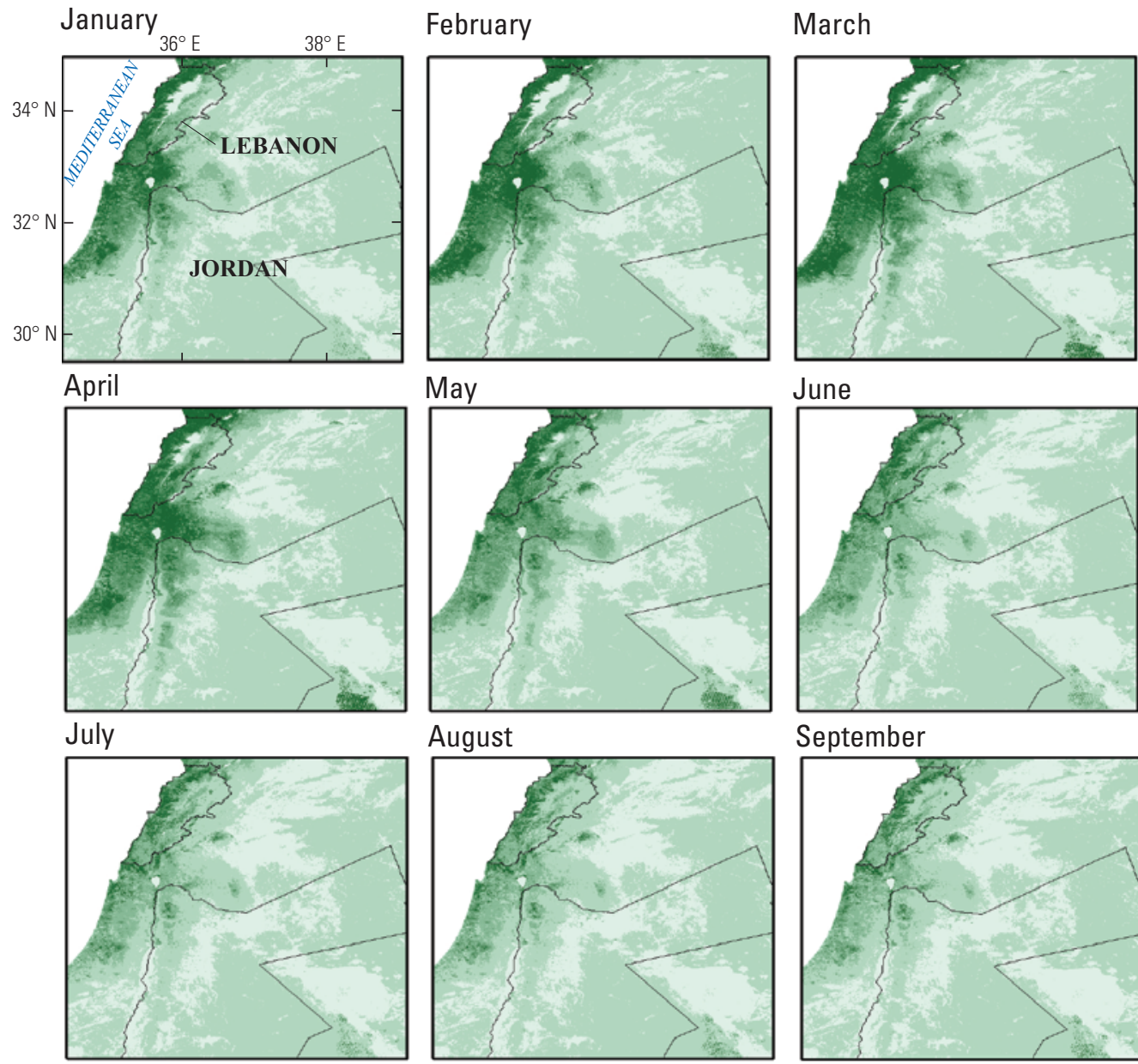

September

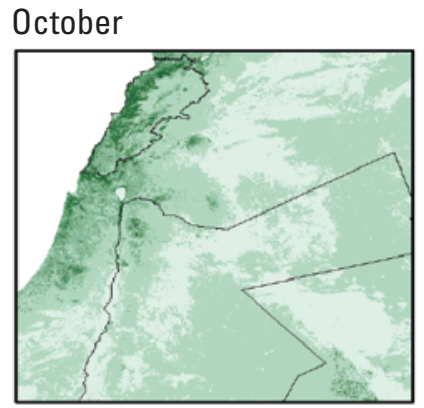

November

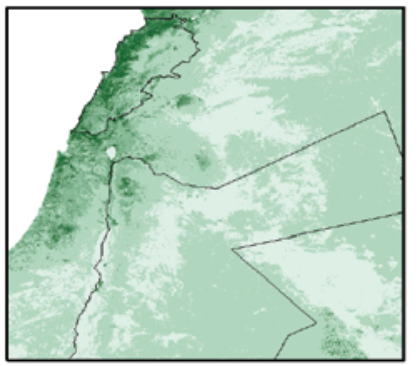

Base from Geodetic System of 1984 (GCS_WGS_1984)

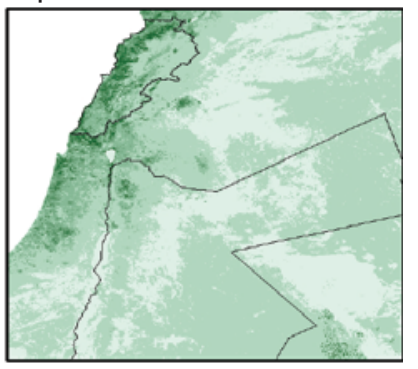

\section{December}

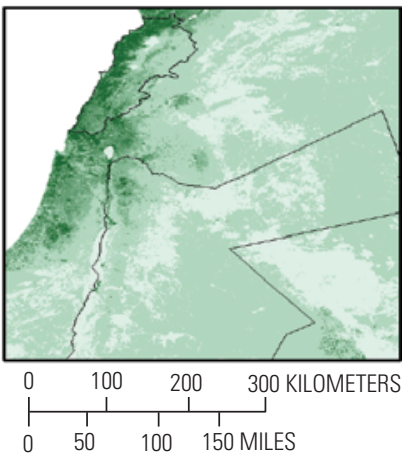

EXPLANATION

Normalized Difference Vegetation Index (dimensionless)

$\begin{array}{lllllll}0 & 0.1 & 0.2 & 0.3 & 0.4 & 0.5 & 0.9\end{array}$

Figure 5. Monthly average Normalized Difference Vegetation Index (NDVI) estimated from remote sensing data for the modeled domain in Lebanon, Jordan, and surrounding areas, $2001-15$. 

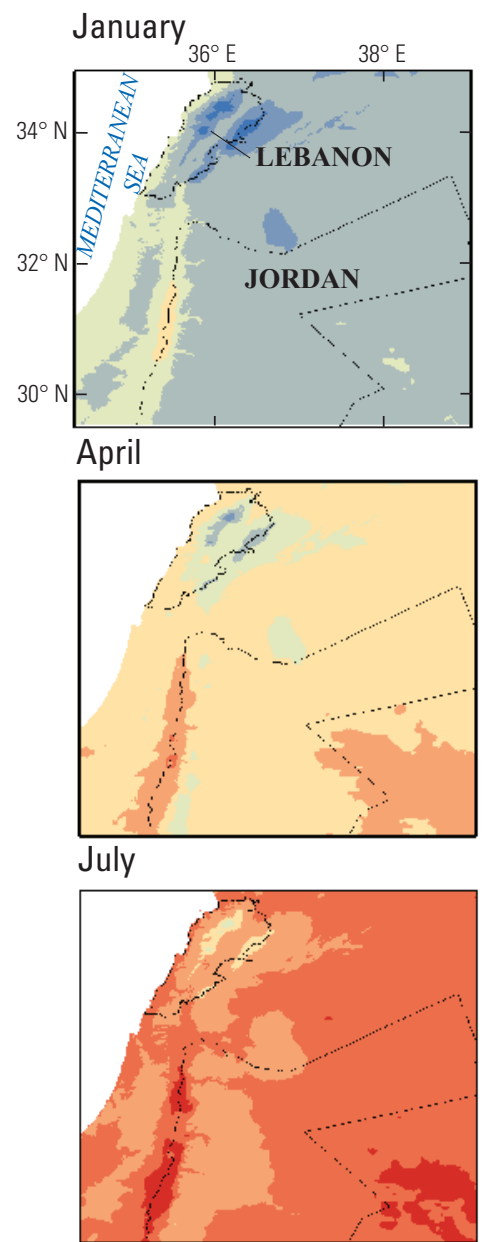

October

February

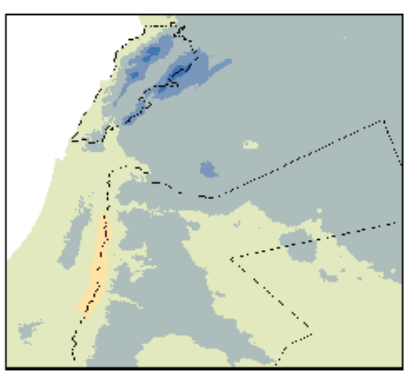

May

March

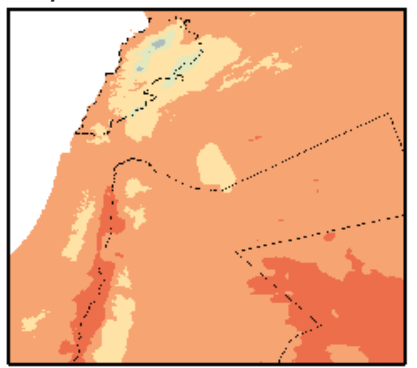

August

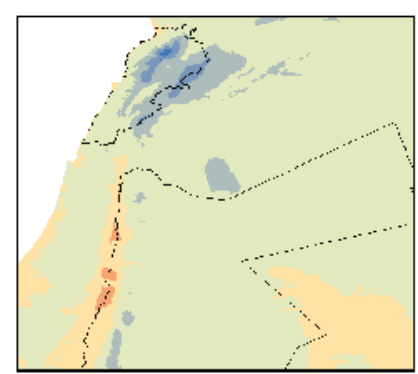

June
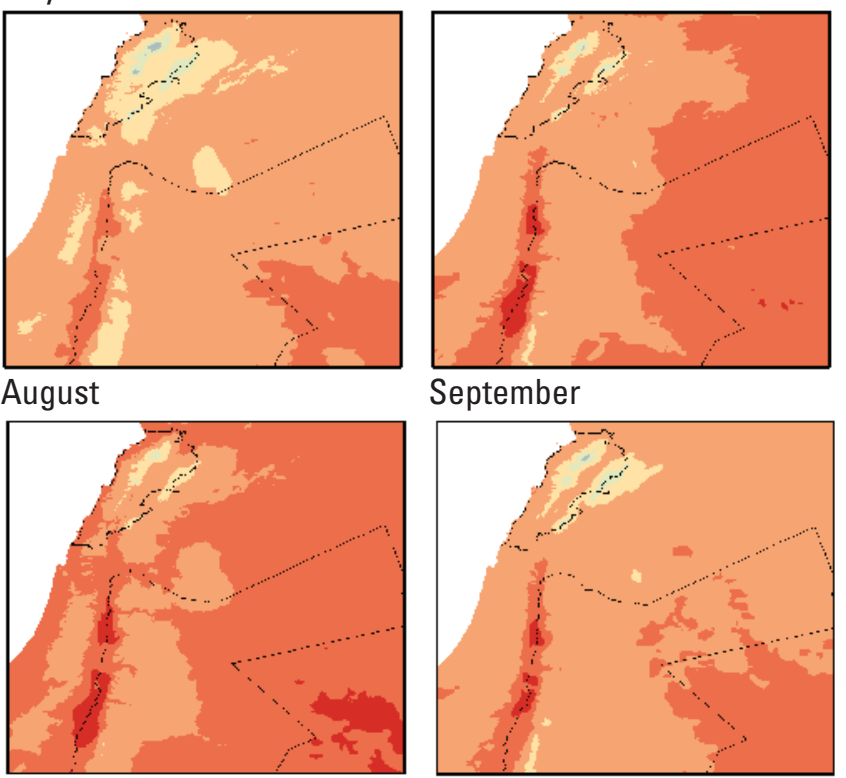

November

September
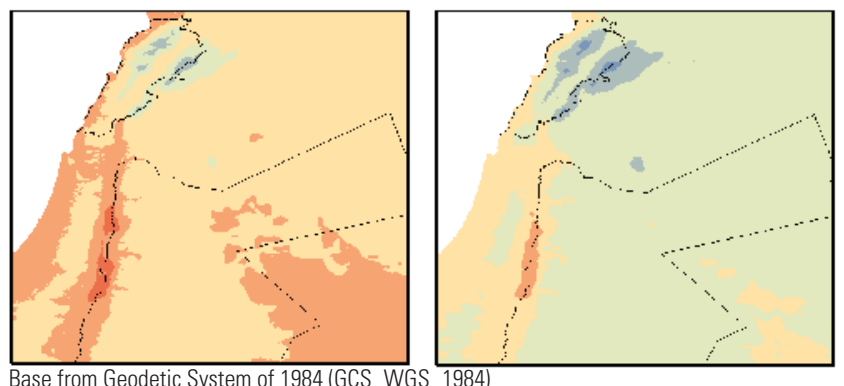

EXPLANATION

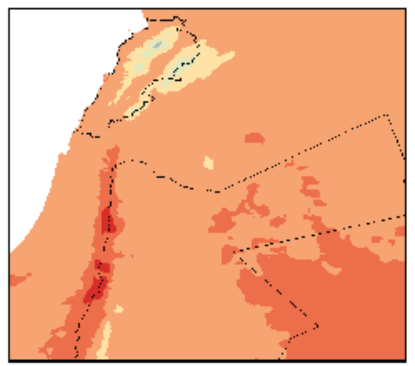

December

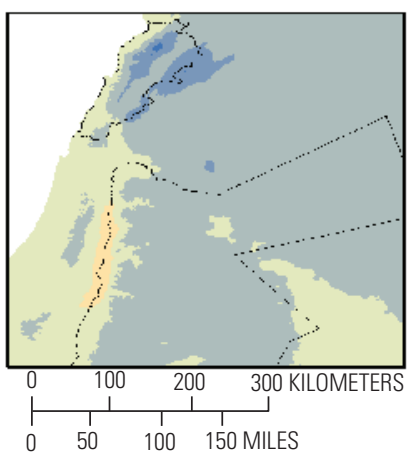

Air temperature, in degrees Celsius

$\begin{array}{lllllllll}-5 & 0 & 5 & 10 & 15 & 20 & 25 & 30 & 35\end{array}$

Figure 6. Monthly average land surface air temperature for the modeled domain in Lebanon, Jordan, and surrounding areas, 1970-2000 (Fick and Hijmans, 2017). 


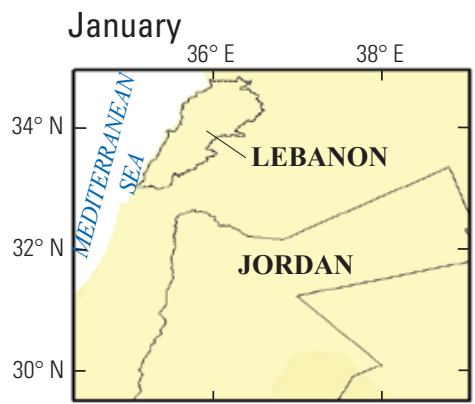

February

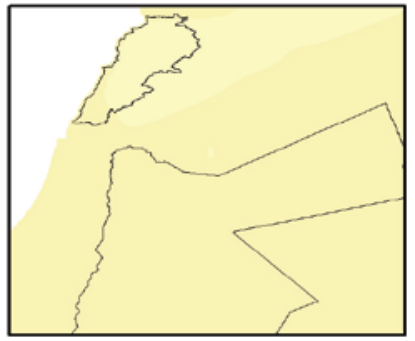

April

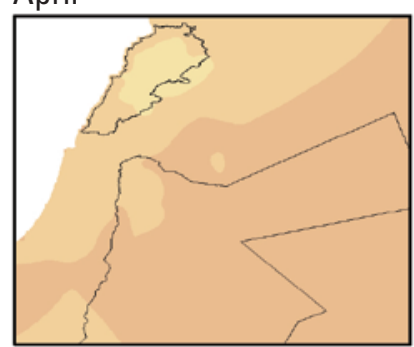

July

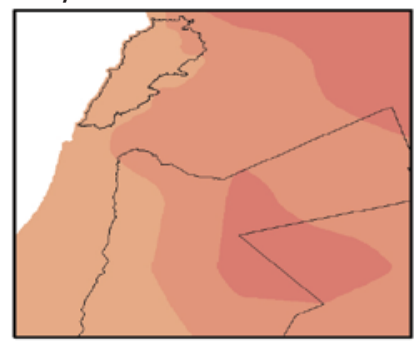

October

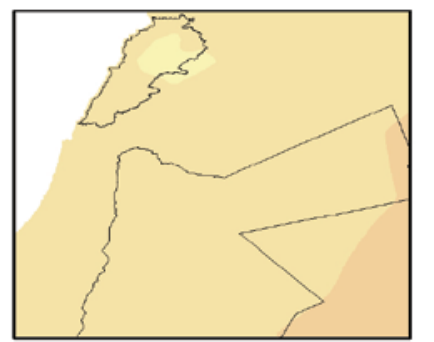

Base from Geodetic System of 1984 (GCS_WGS_1984)

\section{EXPLANATION}

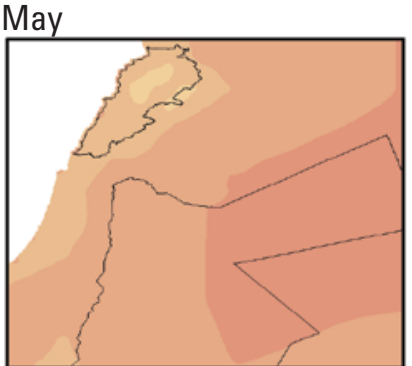

August

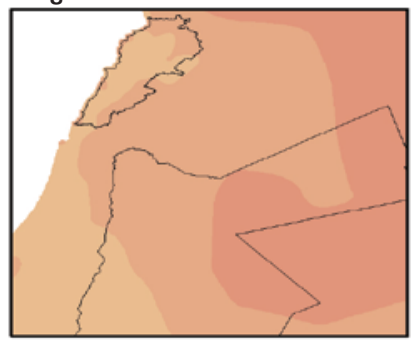

November

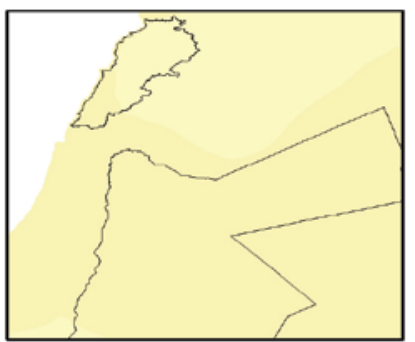

Reference evapotranspiration in millimeters
March

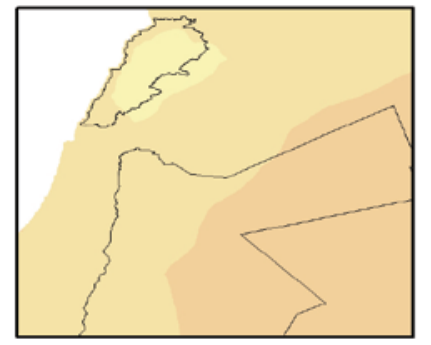

June

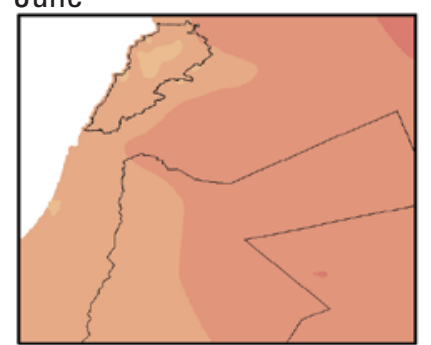

September

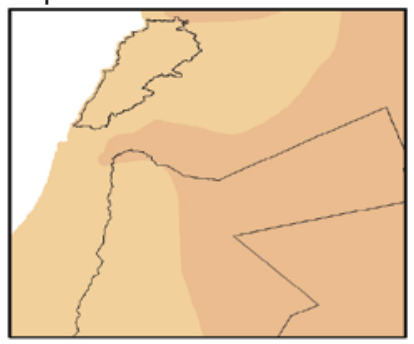

December

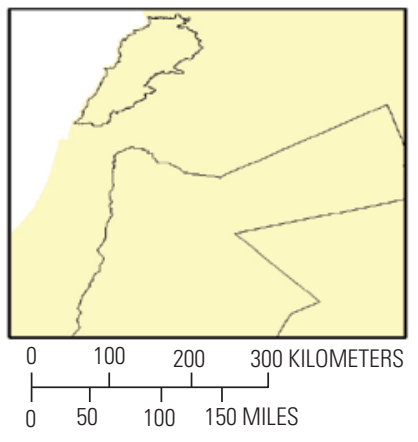

$\begin{array}{llllllllll}1 & 2 & 3 & 4 & 5 & 6 & 7 & 8 & 9 & 10\end{array}$

Figure 7. Monthly average reference evapotranspiration for the modeled domain in Lebanon, Jordan, and surrounding areas, 2003-17. 


\section{Regional Runoff Simulation}

Runoff and actual evapotranspiration (ETa) were simulated with the VegET model (Senay, 2008) using daily input data from remote sensing and modeled datasets. The model calculates ETa (in millimeters [mm]) as

$$
\mathrm{ETa}=\mathrm{Kcp} * \mathrm{Ks} * \mathrm{ETo}
$$

where

$$
\begin{aligned}
& \text { Kcp is the NDVI-derived crop coefficient } \\
& \text { (dimensionless), } \\
& \text { Ks is soil water stress coefficient (dimension- } \\
& \text { less), and } \\
& \text { ETo is reference ET (mm). }
\end{aligned}
$$

For a detailed description of the Kcp and Ks parameters, refer to Senay (2008) and Senay and Verdin (2003).

The daily soil water (SW) level determines the partitioning of precipitation into ETa and runoff. SW is determined using a daily soil water accounting. When the soil water level is above 50 percent of the available water (the difference between field capacity and wilting point), ETa is the same as the maximum ET (ETo), but when the daily soil water level is below 50 percent, ETa reduces linearly as function of the remaining soil water in relation to the 50-percent threshold. Runoff is determined using the saturation excess principle, in other words, moisture in excess of the water holding capacity of the soil is considered runoff. Thus, runoff only occurs when the daily precipitation that does not evaporate or transpire exceeds the soil's moisture storage capacity (fig. 8).

The runoff is defined as

$$
\mathrm{RF}=\mathrm{SWi}-\mathrm{WHC}
$$

where

$$
\begin{aligned}
& \mathrm{RF} \text { is runoff; } \\
& \text { SWi is the initial soil water level after accounting }
\end{aligned}
$$

After an initial evaluation of the runoff with streamgage measurements, which revealed an underestimation, the original model setup was reparameterized by incorporating (1) snowmelt equivalent estimation and (2) the separation of runoff into surface runoff and deep drainage. The consideration of the water provided by snowmelt is useful for regions where a snowpack retains the water during the winter instead of immediately draining to runoff or storage as soil moisture. The snow water equivalent (SWE) was calculated as

$$
\text { swe }=\left(1-\operatorname{rain}_{\text {frac }}\right) * p p t_{\text {eff }}
$$

where

$$
\begin{aligned}
& \operatorname{rain}_{\text {frac }} \quad \text { is the fraction of effective precipitation } \\
& \left(p p t_{\text {eff }}\right) \text { based on the daily average air tem- } \\
& \text { perature, and } \\
& p p t_{\text {eff }} \quad \text { is part of the precipitation after intercep- } \\
& \text { tion losses-which are a function of cover } \\
& \text { type-with coefficients ranging from } 0 \\
& \text { (bare ground) to } 0.1 \text { (herbaceous cover) to } \\
& \text { 0.15 (tree cover). }
\end{aligned}
$$

In the study area, if the daily average temperature $\left(T_{a v g}\right)$ was below $6{ }^{\circ} \mathrm{C}$ all precipitation was assumed to fall as snow $\left(\right.$ rain $\left._{\text {frac }}=0\right)$. If the average temperature for one day was above $12{ }^{\circ} \mathrm{C}$ all precipitation was assumed to be rainfall $\left(\operatorname{rain}_{\text {frac }}=1\right)$; between 6 and $12^{\circ} \mathrm{C}$, the fraction was adjusted based on linear interpolation $\operatorname{rain}_{\text {frac }}=\frac{1}{12} *\left(T_{\text {avg }}-0\right)$. This approach is adapted from Lutz and others (2010) and Tercek and Rodman (2016). The minimum and maximum thresholds of 6 and 12 ${ }^{\circ} \mathrm{C}$, respectively, were decided based on the analysis that the daily average air temperature provided by WorldClim never falls below $0{ }^{\circ} \mathrm{C}$, even at higher elevation locations (about $3,000 \mathrm{~m}$ ) in the Lebanon Mountains.

The snowmelt was calculated based on the melt rate (eq. 4) and the snow water equivalent (eq. 3)

$$
\text { melt }=0.06 *((\text { tmax } * \text { tmax }))-(\text { tmax } * \text { tmin }))
$$

where
0.06
is the melt factor,
tmax is the maximum air temperature $\left({ }^{\circ} \mathrm{C}\right)$, and tmin is the minimum air temperature $\left({ }^{\circ} \mathrm{C}\right)$.

The equation is adapted from Moussavi and others (1989).

Deep drainage or groundwater recharge is infiltration of precipitation through soil down to the saturated zone of groundwater. Discharge of flowing groundwater to streams and wadis is called base flow, which typically supports perennial stream flow. In contrast, surface runoff constitutes the component that runs off the land as overland flow. The separation of surface runoff and deep drainage requires an important partitioning parameter, the runoff coefficient ( $\mathrm{rc}$ ), but does not affect the availability of runoff if the surface and groundwater systems are hydraulically connected. The deep drainage is calculated as

$$
d d=r f-s r f
$$

where

$$
\begin{array}{cl}
d d & \text { is deep drainage }(\mathrm{mm}), \\
r f & \text { is the total runoff }(\mathrm{mm}), \text { and } \\
s r f & \text { is the direct surface runoff }(\mathrm{mm}) .
\end{array}
$$

The $r f$ value is determined to be the difference between the soil water amount and soil water holding capacity value. 

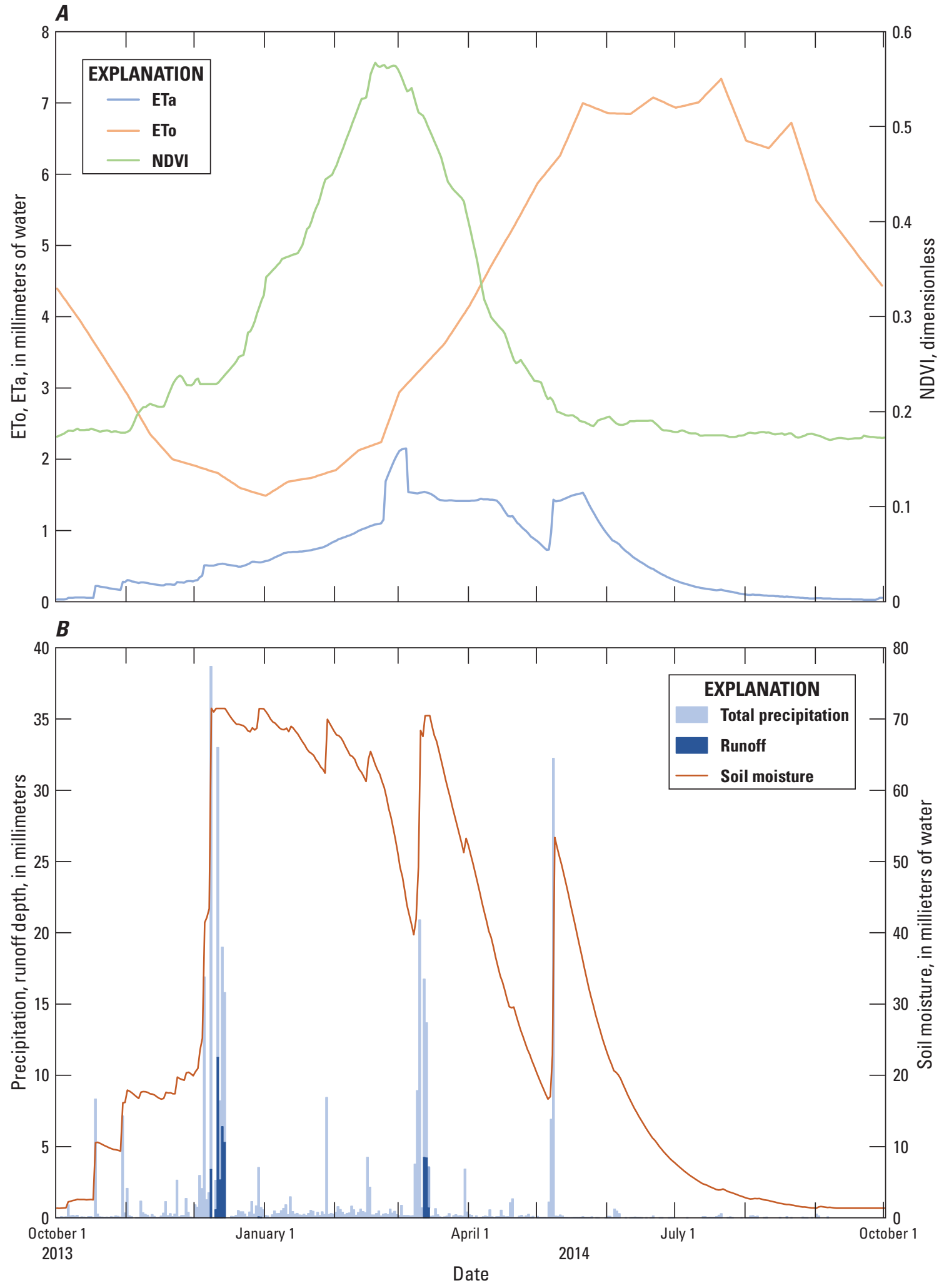

Figure 8. Example VegET daily model simulation for a single pixel location of $A$, actual evapotranspiration (ETa) based on daily reference evapotranspiration (ETo) and median daily Normalized Difference Vegetation Index (2001-15), and $B$, simulated surface runoff and soil moisture changes from daily precipitation, for water year 2014. 
The $\operatorname{srf}$ value is estimated based on soil water level and a drainage coefficient $(d c)$ as

$$
\begin{gathered}
s r f=i f\left(r f \leq s a t_{f c}\right): r c * r f \\
\text { elseif }\left(r f \geq s a t_{f c}\right):\left(r f-s a t_{f c}\right)+r c^{*} s a t_{f c}
\end{gathered}
$$

where

$$
\begin{array}{cl}
r f & \text { is runoff }(\mathrm{mm}) ; \\
s a t_{f c} & \text { is the difference between the soil saturation } \\
\text { amount and field capacity; and } \\
r c \quad \text { is the runoff coefficient, deter- } \\
\text { mined as } r c=1-\text { drainage } \\
\text { coefficient }(d c=0.65)=0.35 .
\end{array}
$$

The values of $r c$ and $d c$ require proper calibration using measured runoff, but they were estimated here from the relative magnitude. Although this will introduce a bias error in the runoff estimation, the spatiotemporal variability will be affected much less, because these multipliers uniformly raise or lower estimated runoff at all locations. Hence the biased runoff estimates can still be useful for comparing different areas.

Runoff is the highest during the cold season between December and March (fig. 8). During this period the soil moisture is replenished, providing opportunities for runoff generation and aquifer recharge. The reference ET (ETo) is high during the warmer months from May to September, while the actual ET (ETa) peaks during the spring period between March and June, in correspondence with vegetation growth in the region and the available supply of soil moisture. As spring turns to summer the soil dries out and the vegetation ceases transpiring.

A more detailed look at the ETa parameter over water year 2014 (fig. 8) demonstrates that the highest ETa amounts occur from March to May, when water is available from precipitation and snowmelt. In the warm season, from July to September, the ETa is generally much lower (fig. 9A). The year-to-year variability of the ETa for selected years from 1984 to 2015 is illustrated in figure $9 B$; the pattern is consistent with some years (for example, 1994, 2006) having a larger magnitude in northern Jordan as a result of higher rainfall during those years.

The simulated average surface runoff (fig. 10) from month to month follows the other datasets by having increased runoff available from December to February and having extended periods of runoff available in the Lebanon Mountains owing to the slower melting of the snowpack in the spring. The variability of runoff is consistent with the precipitation variability from year to year, with relatively more runoff during high precipitation years.

The primary objective of this study was to determine water availability for aquifer recharge. Therefore, annual accumulated surface runoff rasters (figs. 11, 12) were created with Esri's ArcMap software (ver. 10.7.1, Toolbox: Hydrology, Tool: Flow Accumulation) using the flow-direction grid derived from the digital elevation model (DEM). To quantify the water availability reliability, the coefficient of variation (the standard deviation divided by the 32-year mean) was computed (fig. 13); this indicates the variability of the annual accumulated surface runoff during the 32-year period. 


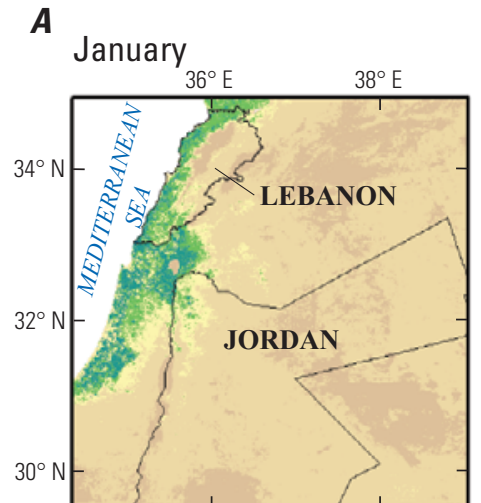

February

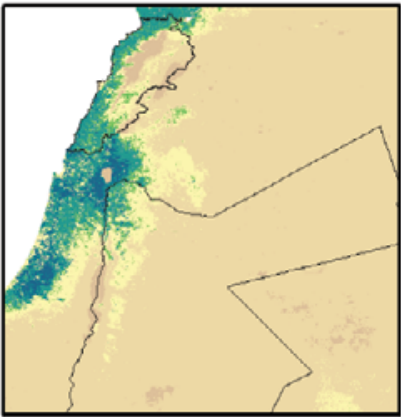

$$
\text { April }
$$

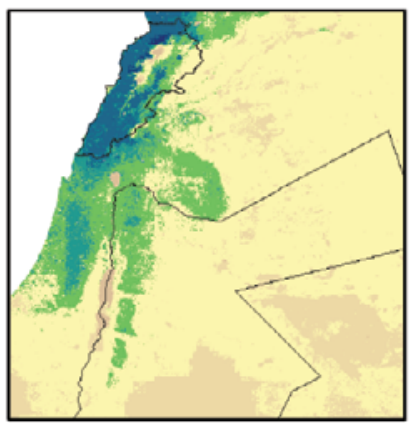

$$
\text { July }
$$

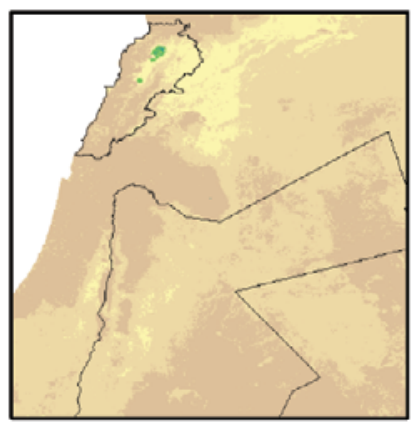

October

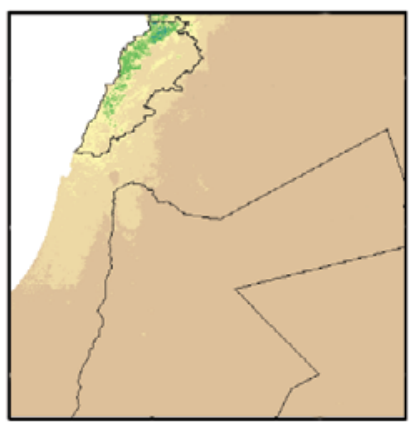

Base from Geodetic System of 1984 (GCS_WGS_198

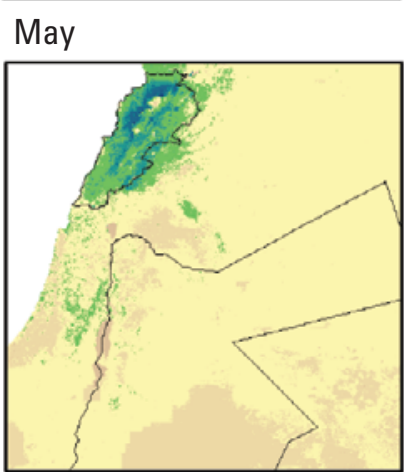

August

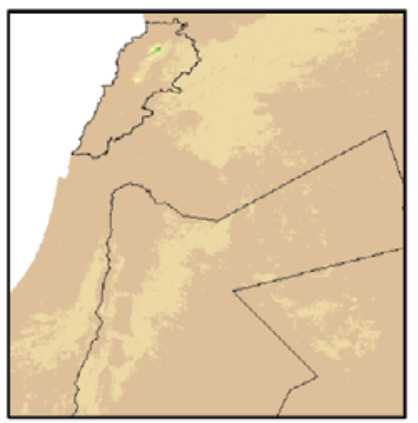

November

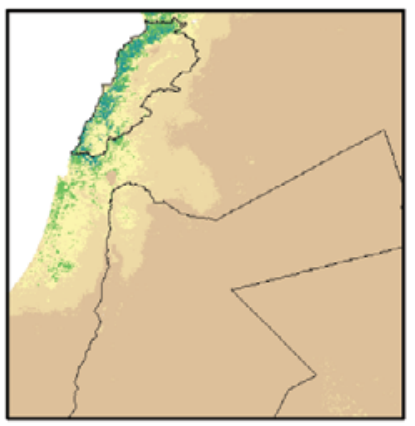

EXPLANATION
March

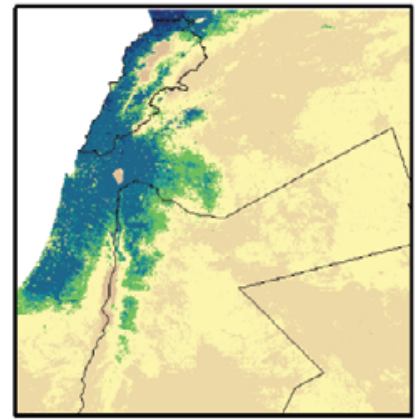

June

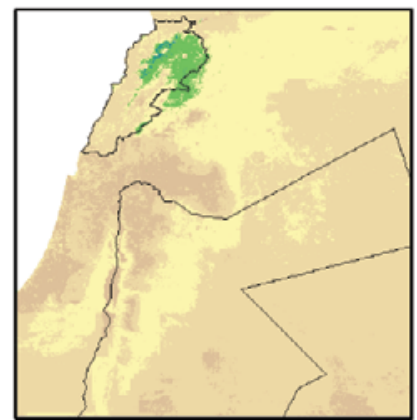

September

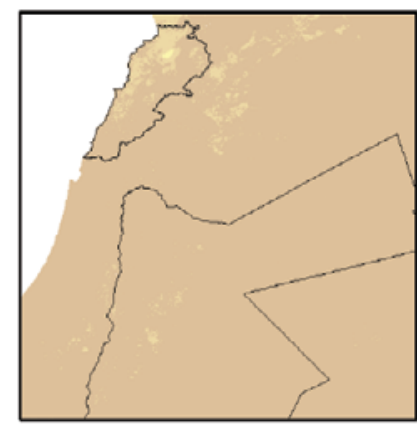

December

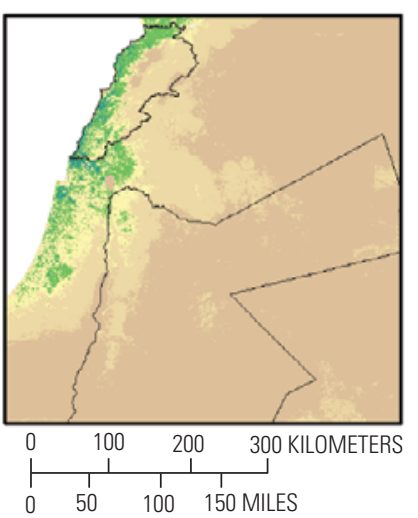

Actual evapotranspiration, in millimeters

$\begin{array}{llllllll}0 & 5 & 15 & 30 & 45 & 60 & 90 & 120\end{array}$

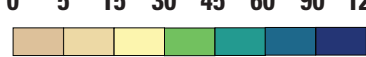

Figure 9. Actual evapotranspiration simulated for the modeled domain in Lebanon, Jordan, and surrounding areas, 1984-2015: A, Average monthly evapotranspiration, and $B$, Annual evapotranspiration for selected years and the period average annual evapotranspiration. 


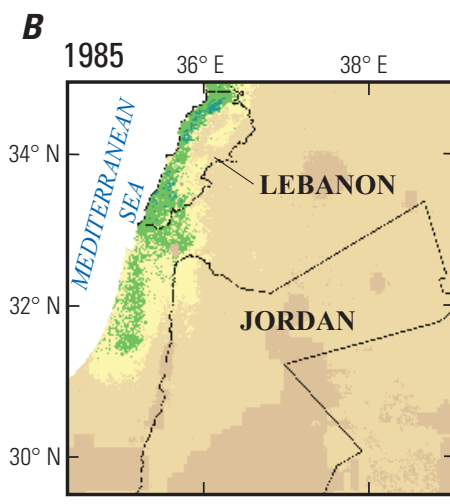

1988

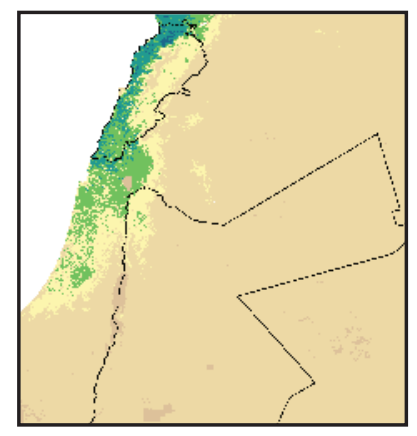

1991

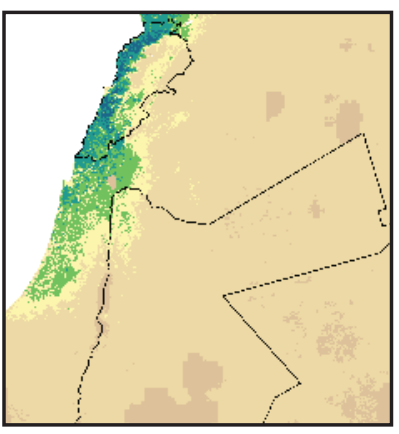

1994

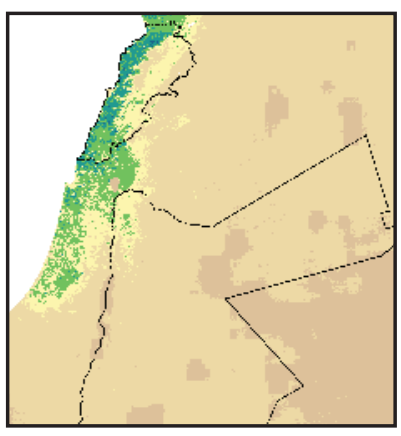

1997

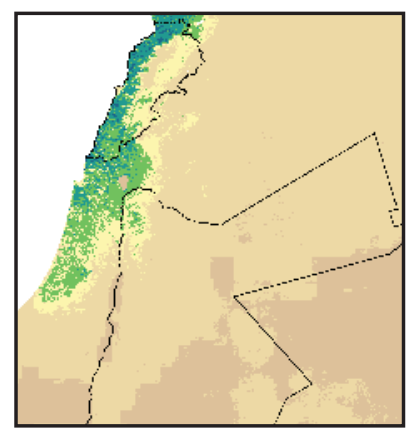

2000

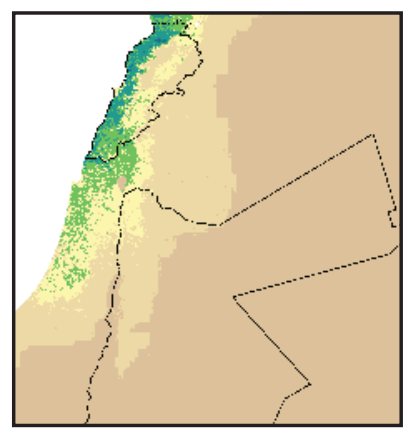

2003
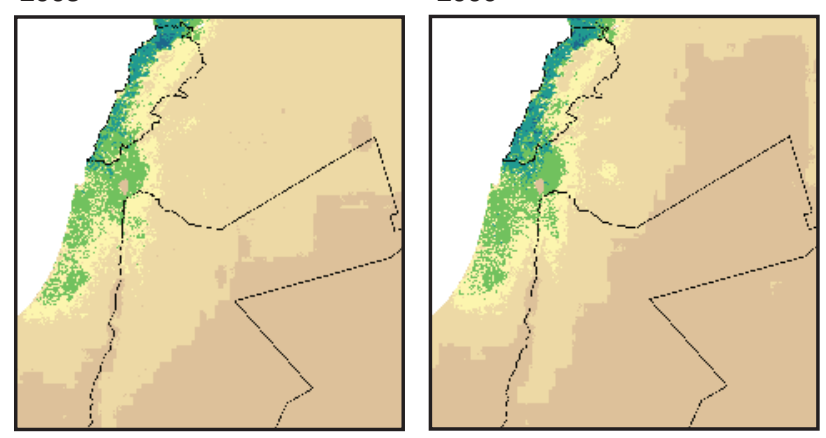

2015
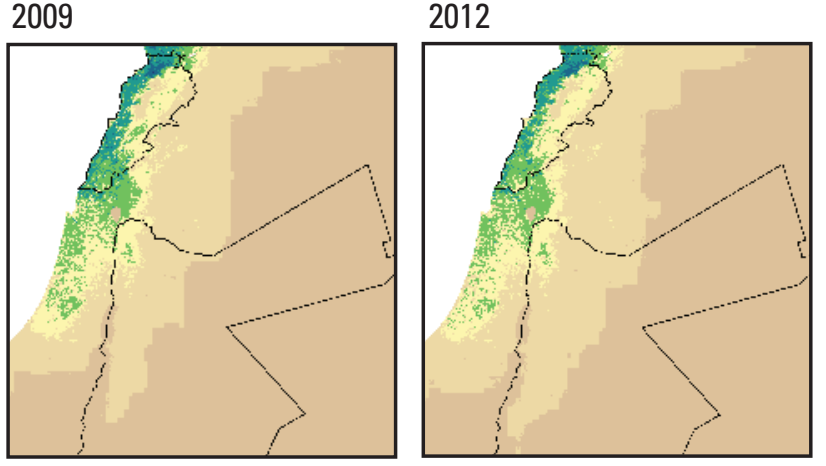

Base from Geodetic System of 1984 (GCS_WGS_1984)

\section{EXPLANATION}

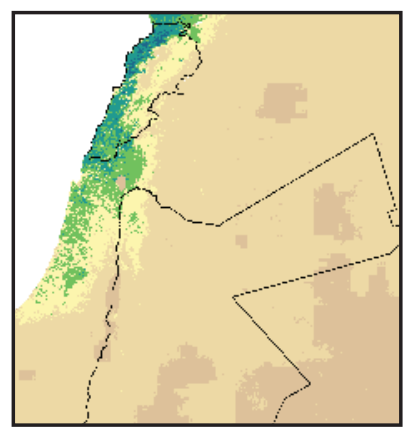

Average

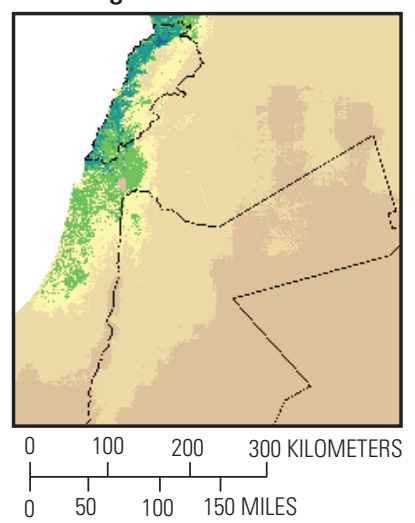

Actual evapotranspiration, in millimeters

Figure 9. Actual evapotranspiration simulated for the modeled domain in Lebanon, Jordan, and surrounding areas, 19842015: $A$, Average monthly evapotranspiration, and $B$, Annual evapotranspiration for selected years and the period average annual evapotranspiration.-Continued 


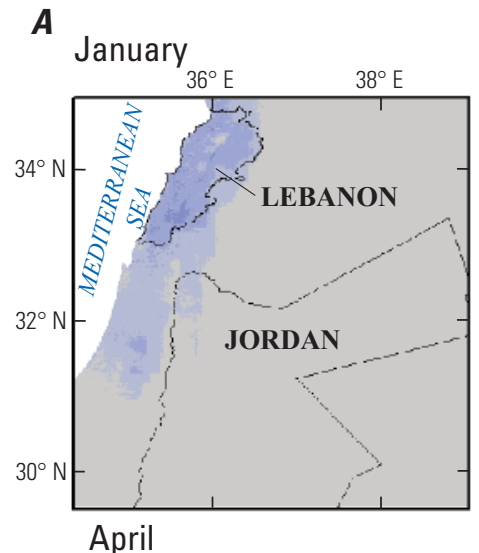

February

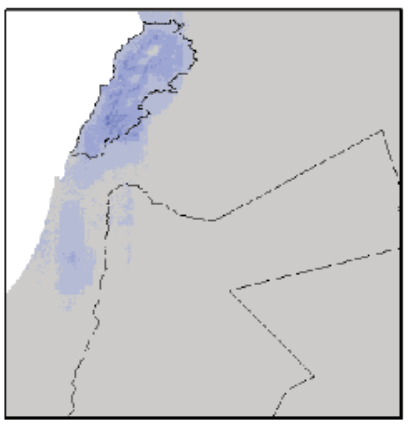

May

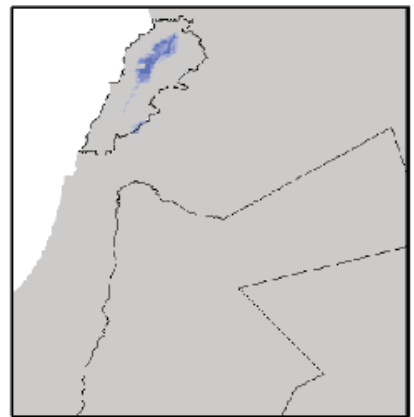

July

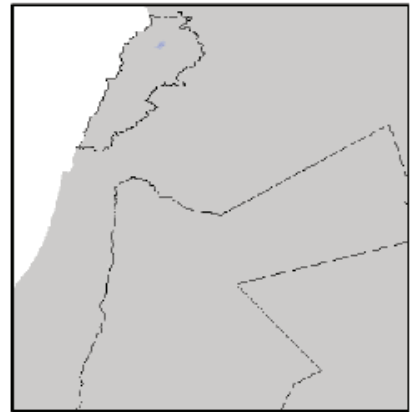

October

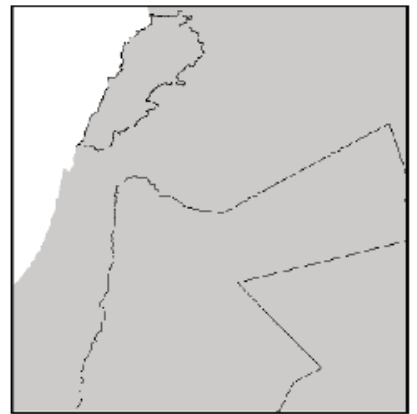

Base from Geodetic System of 1984 (GCS_WGS_1984

Surface runoff, in millimeters

$\begin{array}{llllll}0 & 25 & 50 & 75 & 100 & 150\end{array}$
March

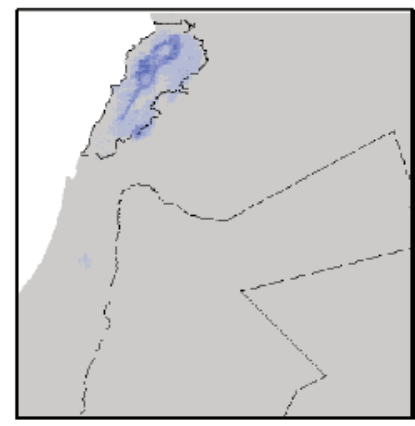

June

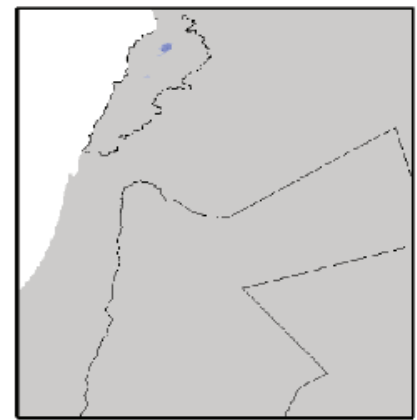

September

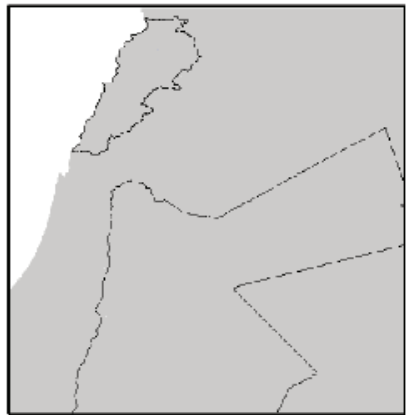

December

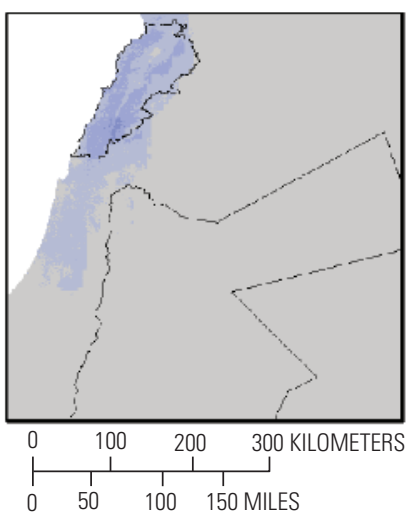

Figure 10. Surface runoff simulated for the modeled domain in Lebanon, Jordan, and surrounding areas, 1984-2015: $A$, Average monthly surface runoff, and $B$, Annual surface runoff for selected years and the period average annual surface runoff. 


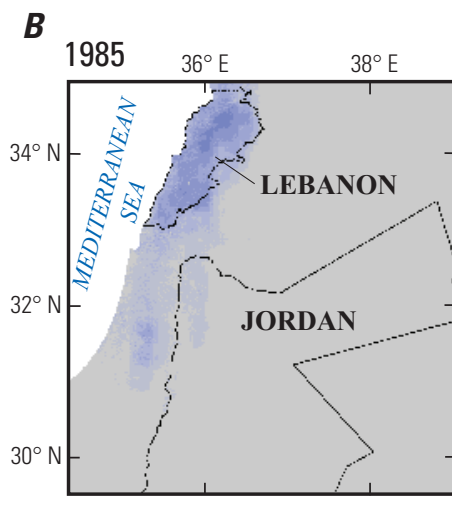

1988

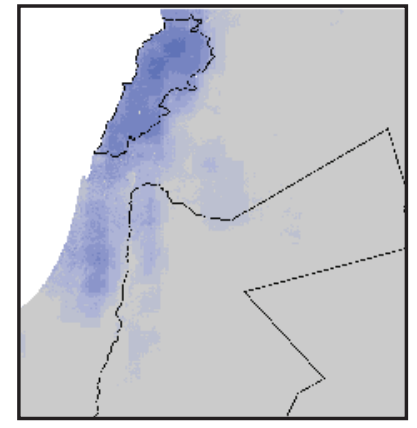

1991

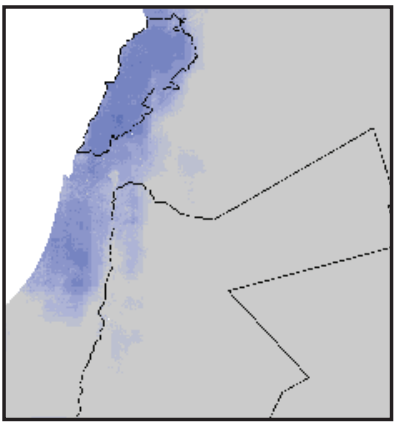

2003

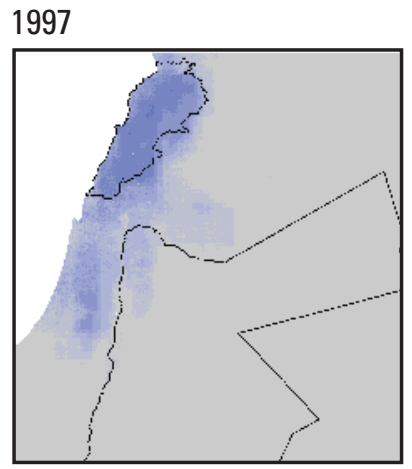

2000
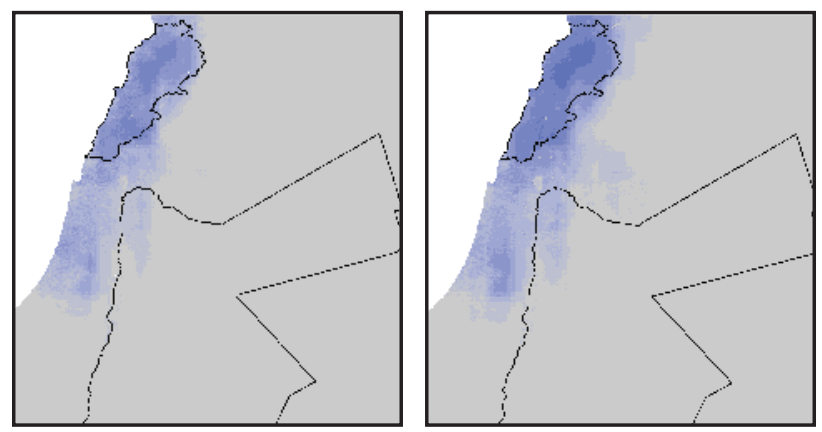

2009

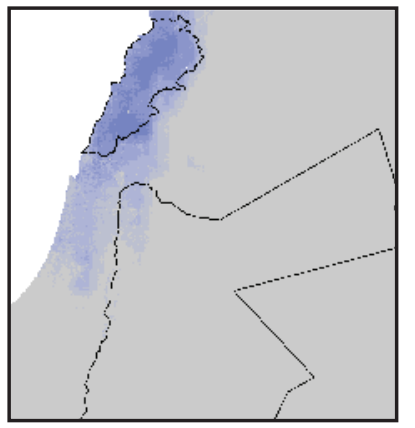

2012

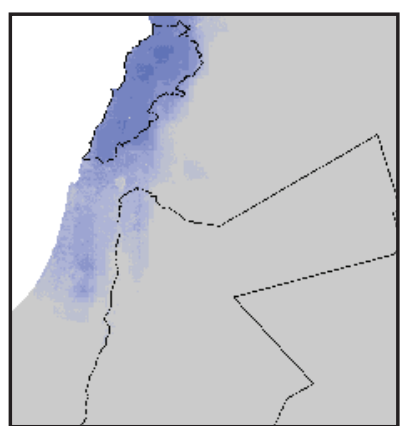

Base from Geodetic System of 1984 (GCS_WGS_1984)

\section{5}

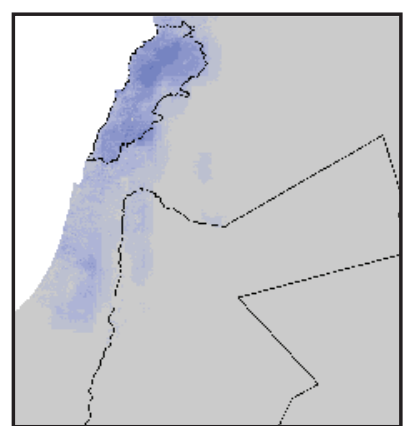

EXPLANATION
2006

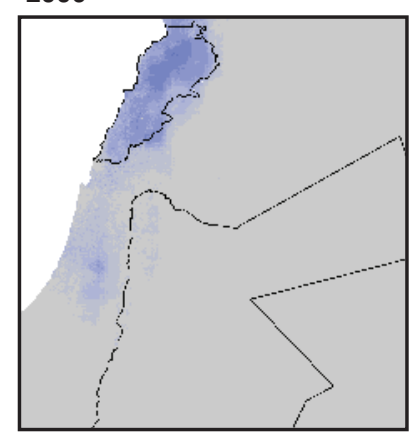

1994

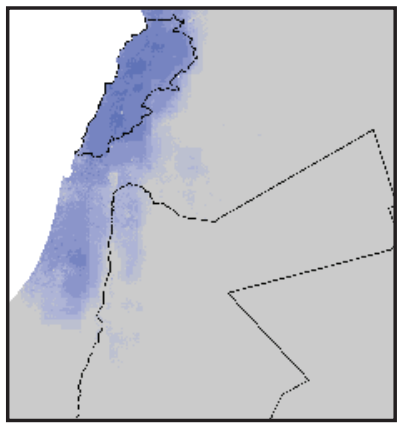

006

Average

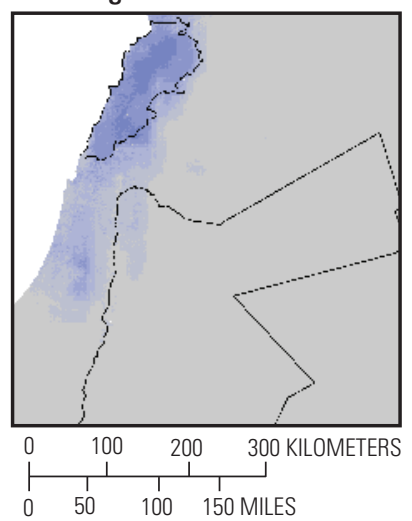

Surface runoff, in millimeters

$\begin{array}{llllllll}0 & 50 & 100 & 150 & 200 & 300 & 500 & 1,000\end{array}$

Figure 10. Surface runoff simulated for the modeled domain in Lebanon, Jordan, and surrounding areas, 1984-2015: $A$, Average monthly surface runoff, and $B$, Annual surface runoff for selected years and the period average annual surface runoff.-Continued 


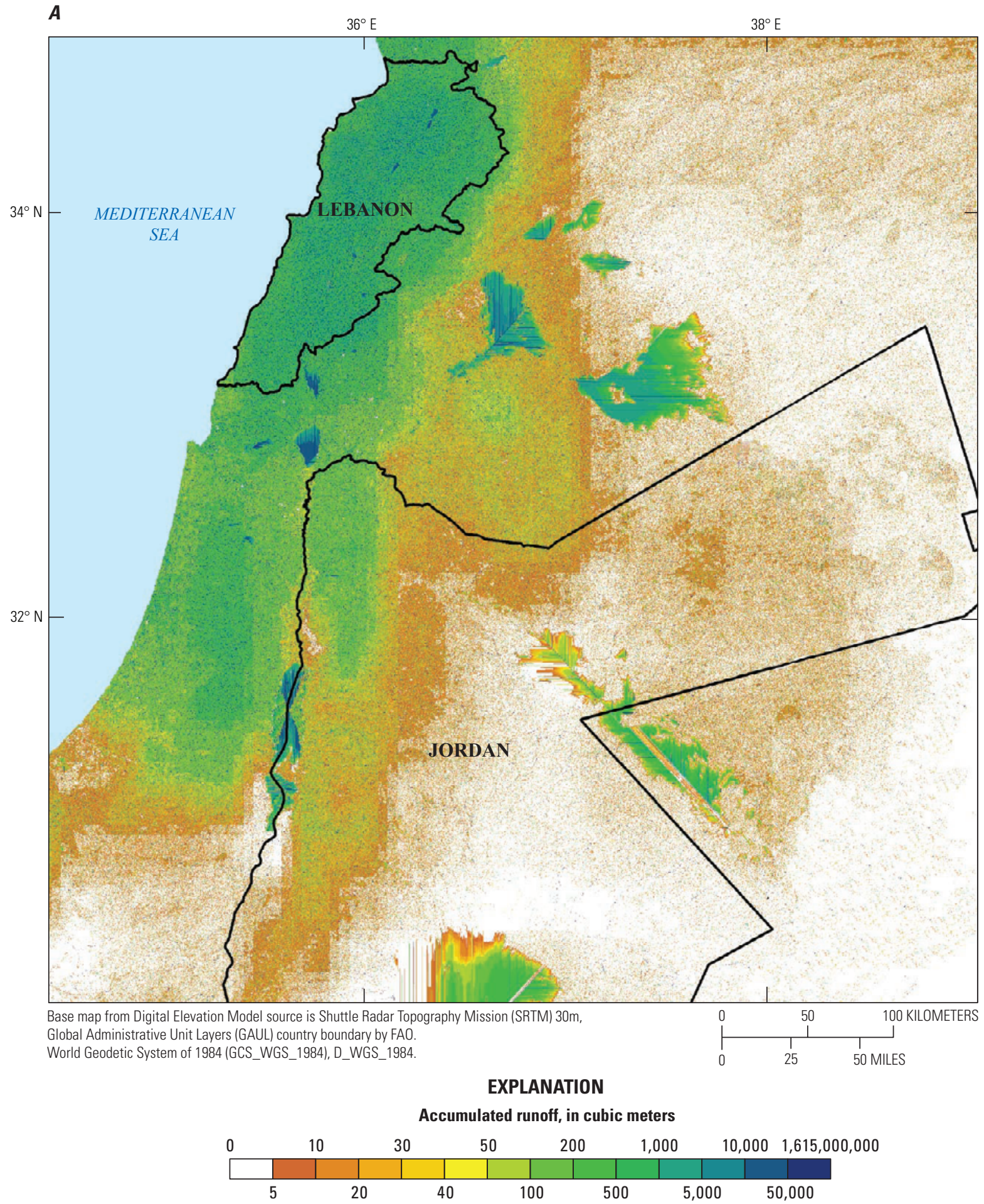

Figure 11. Average annual accumulated surface runoff simulated in Lebanon, Jordan, and surrounding areas, 1984-2015: $A$, for the entire model domain, and $B$, a detail for an area in Lebanon. 


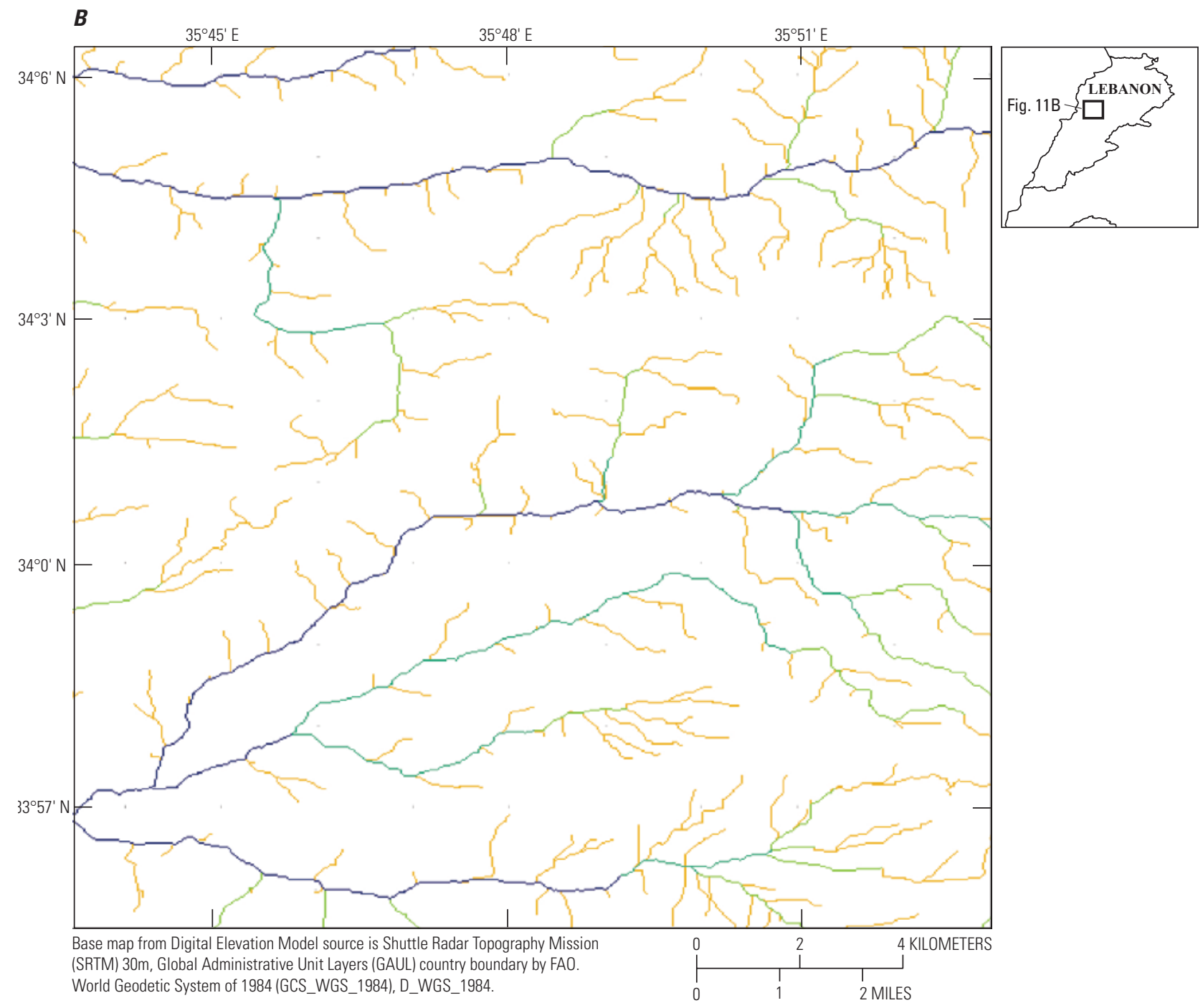

EXPLANATION

Accumulated runoff, in cubic meters

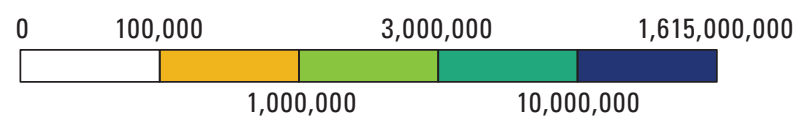

Figure 11. Average annual accumulated surface runoff simulated in Lebanon, Jordan, and surrounding areas, 1984-2015: $A$, for the entire model domain, and $B$, a detail for an area in Lebanon.-Continued 


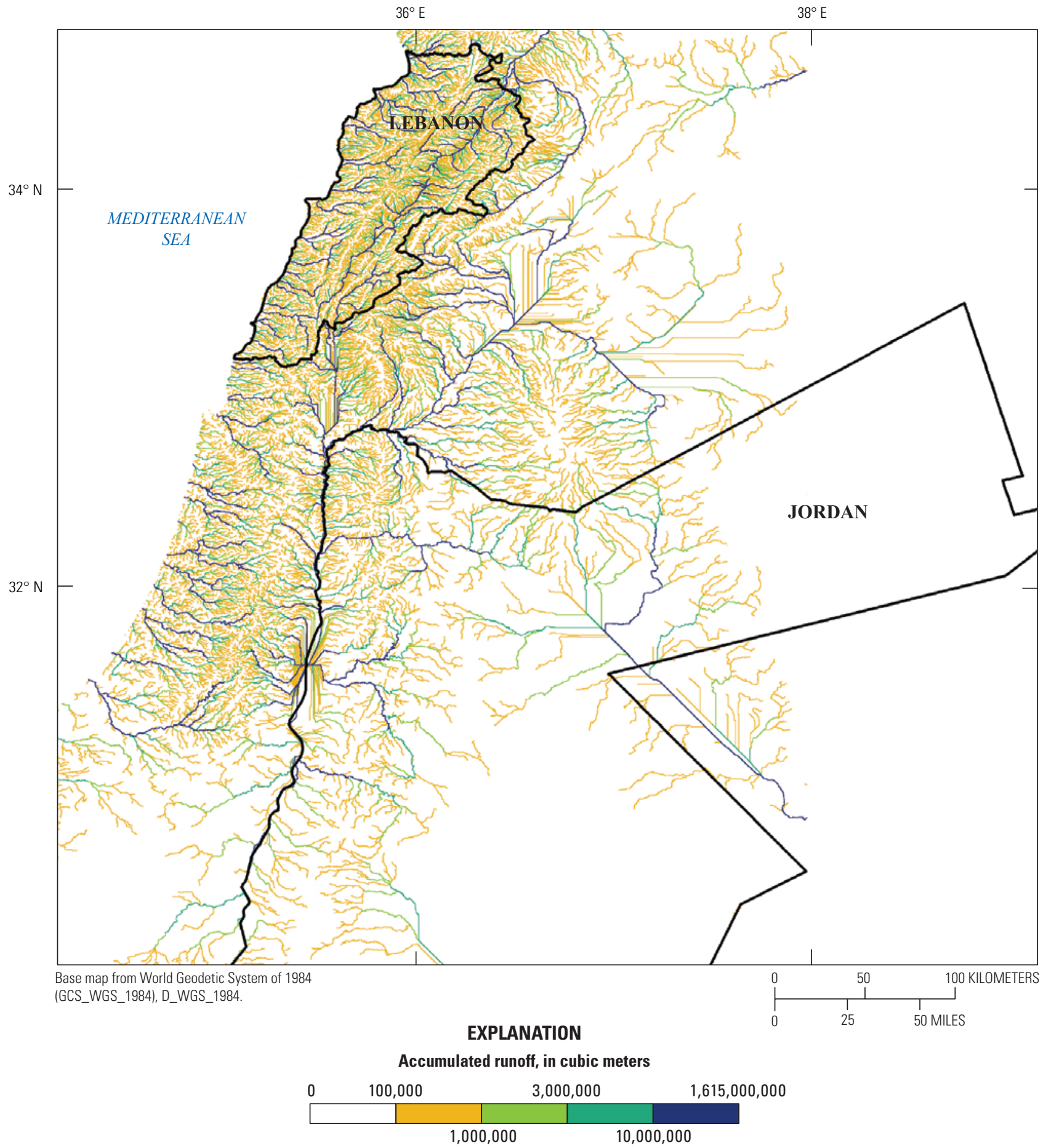

Figure 12. Average annual accumulated surface runoff in streams simulated for the modeled domain in Lebanon, Jordan, and surrounding areas, 1984-2015. Runoff was not accumulated east of $38^{\circ}$ longitude owing to very low surface runoff and flat topography. Stream pixels are enlarged so that streams are several pixels wide, for regional image resolution. 


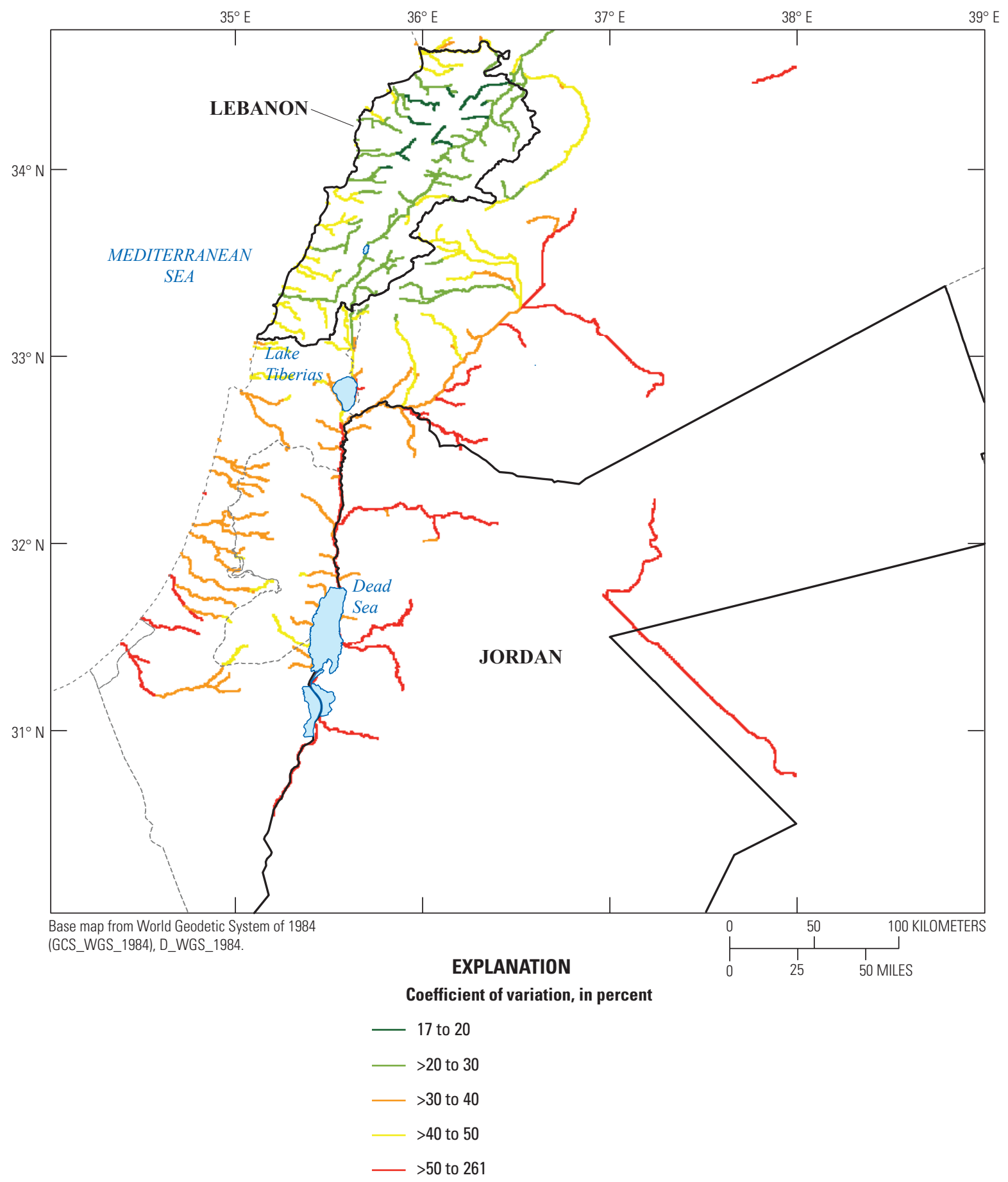

Figure 13. The coefficient of variation of annual accumulated surface runoff simulated for the modeled domain in Lebanon, Jordan, and surrounding areas, 1984-2015. Runoff was not accumulated east of $38^{\circ}$ longitude due to very low surface runoff and flat topography. Results are shown only for locations with a simulated average annual accumulated surface runoff of 10 million cubic meters per year or more. 
Table 1. Streamflow measuring locations used for model calibration, lower Jordan Valley, Jordan. Data provided by Thair Al-Momani, Ministry of Water and Irrigation, Jordan (written commun., 2017).

[W., wadi]

\begin{tabular}{ccc}
\hline Station ID & Station name & Basin name \\
AB0009 & WAQQAS & Jordan River. \\
AD0020 & WAQQAS & Yarmouk River. \\
AD0033 & ADASIYIA & Wadi Arab. \\
AE0400 & WADI ELARAB & Wadi Ziglab. \\
AF0003 & ZAGLAB & Wadi Yabis. \\
AH0005 & ALYABIS & Wadi Kufrinja. \\
AJ0005 & KUFRANIJA & Wadi Rajib. \\
AK0003 & WADI RAJIB 0040 & Wadi Zarqa. \\
AM0008 & W. UM AL-DANANIR & Wadi Shu'eib. \\
AN0006 & WADI SHUEIB AT SHANAT NIMRIN & Wadi Kafrein. \\
\end{tabular}

\section{Runoff Comparison with Monitoring Data}

To evaluate the VegET results, we compared the simulated runoff to continuous and discrete streamflow measurements in Jordan and Lebanon. Streamflow data were available from 12 streamgages located on tributaries flowing into the Jordan River from the east (table 1; fig. 14).

A strong correlation $\left(r^{2}=0.54, r=0.73\right)$ for the Jordan streams suggests modeled values capture the spatial variability of observed runoff volumes, but the simulated flows, which do not include base flow, are lower than the measured flows (fig. 15). The simulated runoff coefficients are about 15 percent of the annual precipitation, whereas the observed values vary from 2 to 40 percent for different streams. The Adasiyia basin has the highest runoff coefficient (fig. 16); it is the largest and most northern basin in the comparison and receives the highest precipitation amount.

Data used for runoff model comparison were available from five streamgages on streams in the Damour River Basin, Lebanon (fig. 17; table 2), which receives water from the

Table 2. Streamflow monitoring stations in the Damour River Basin, Lebanon, used for runoff model comparison.

\begin{tabular}{cc}
\hline Station ID & Station name \\
\hline 43 & Wadi Es Sitt. \\
45 & BouZebli, Rechmaya. \\
46 & Jisr El-Qadi. \\
47 & Al Hammam. \\
48 & Damour Sea Mouth. \\
\hline
\end{tabular}

Lebanon Mountains and flows into the Mediterranean Sea. The comparison of simulated annual stream flow and measurements for Lebanon from 1984 to 2015 is shown in figure 18, along with the runoff coefficient in figure 19. The regression results indicate a strong correlation between the simulated and measured runoff $\left(r^{2}=0.73, r=0.85\right)$ reasonably characterizing the spatial variability of the modeled runoff. A comparison of the average runoff coefficient for each stream (fig. 19) shows that the model captures the overall magnitude for four out of five streams. Bou Zebli Rechmaya has a runoff coefficient of more than 50 percent of the precipitation, which is considered within reason because of snowmelt in its drainage basin in the Lebanon Mountains.

The simulated runoff for Jordan and Lebanon appears to capture the spatial variability well, indicating an appropriate application for comparing different parts of the basin. In some subbasins (for example Adasiyia, Waqqas, and W. Um Al-Dananir), the magnitude of the modeled runoff coefficient is very different from the observed, indicting the model's inability to fully capture the runoff generation and water budget in those basins. Additional examination and testing of the model assumptions, including instantaneous accumulation and no groundwater base flow, would likely identify the error sources. However, the relative magnitudes of the runoff are considered useful for site suitability mapping within the subbasins. It is important to note that the model is based on remotely sensed data and parameterized for the region without a basin-specific calibration. Targeted calibration for each subbasin would improve the absolute accuracy of the model. Sources of error include uncertainty in the satellite-based precipitation, vegetation indices, reference ET, and accuracy of the soils database. The model also does not have a baseflow component from groundwater discharge. 


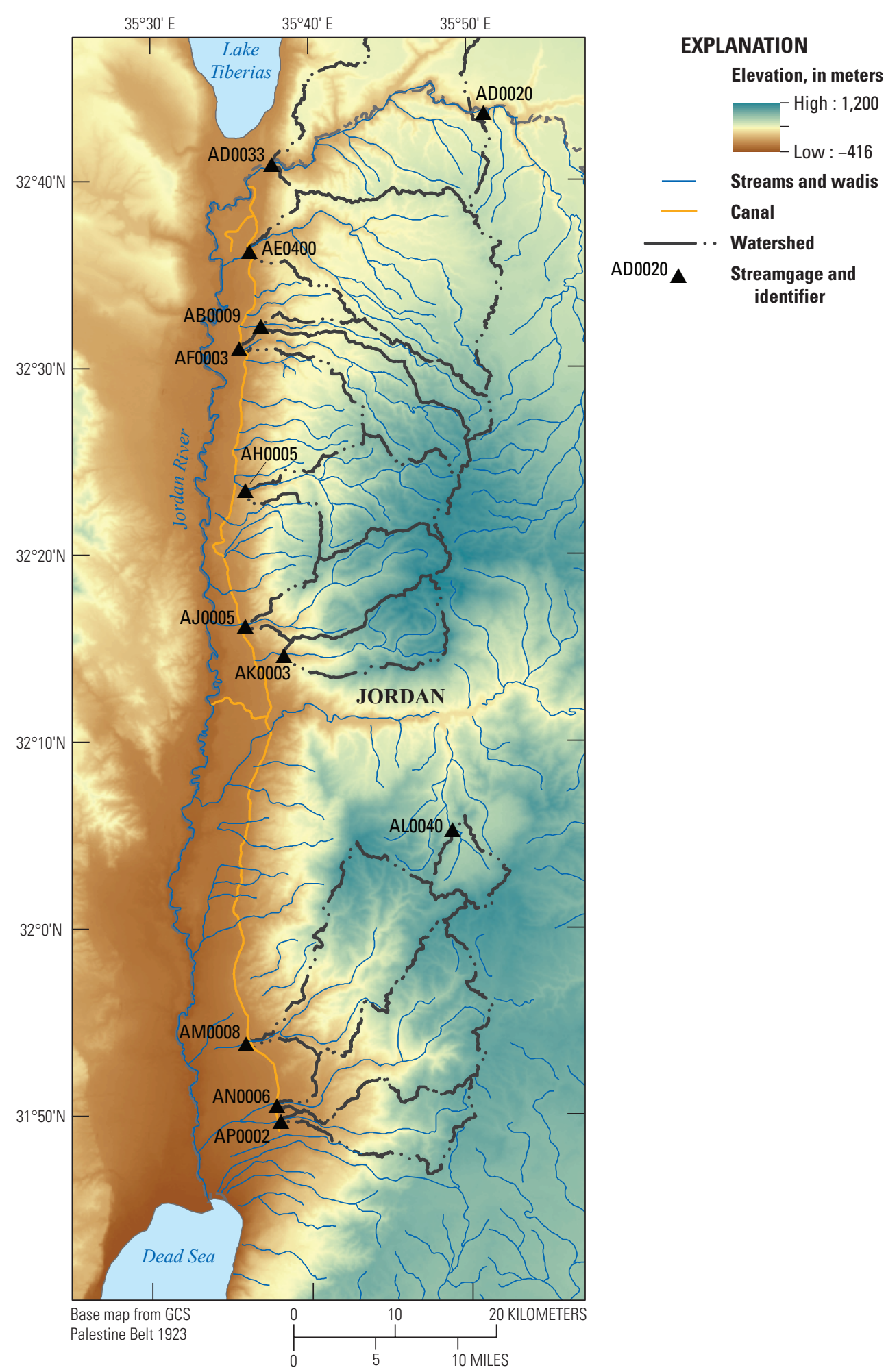

Figure 14. Topography, streamflow measurement locations, and corresponding runoff model subbasins, lower Jordan Valley, Jordan (after Salameh and Abdallat, 2020a, b; Data provided by Thair Al-Momani, Ministry of Water and Irrigation, Jordan, written commun., 2017). 


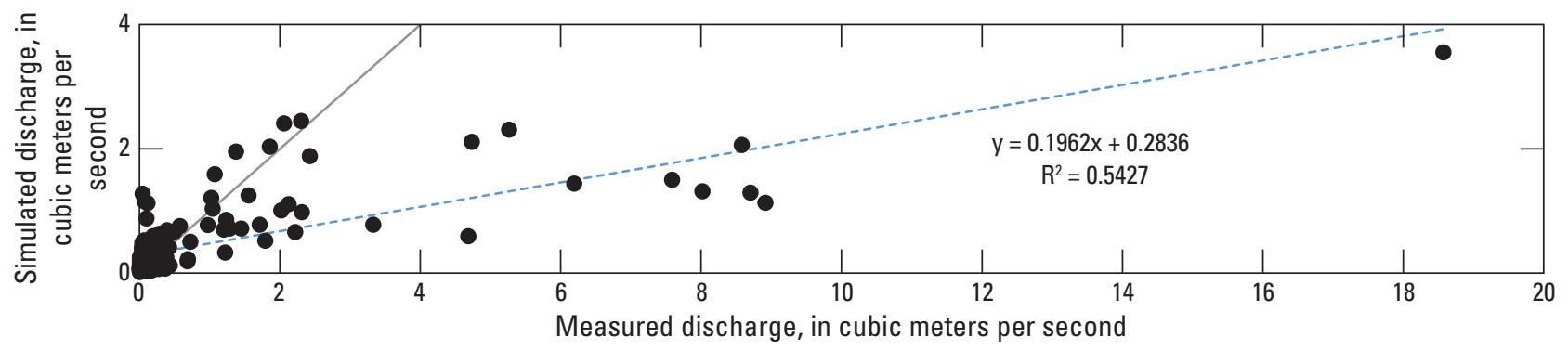

Figure 15. Simulated and measured streamflow at measurement locations in the lower Jordan Valley, Jordan. The identity (1:1) line and linear regression are also shown.

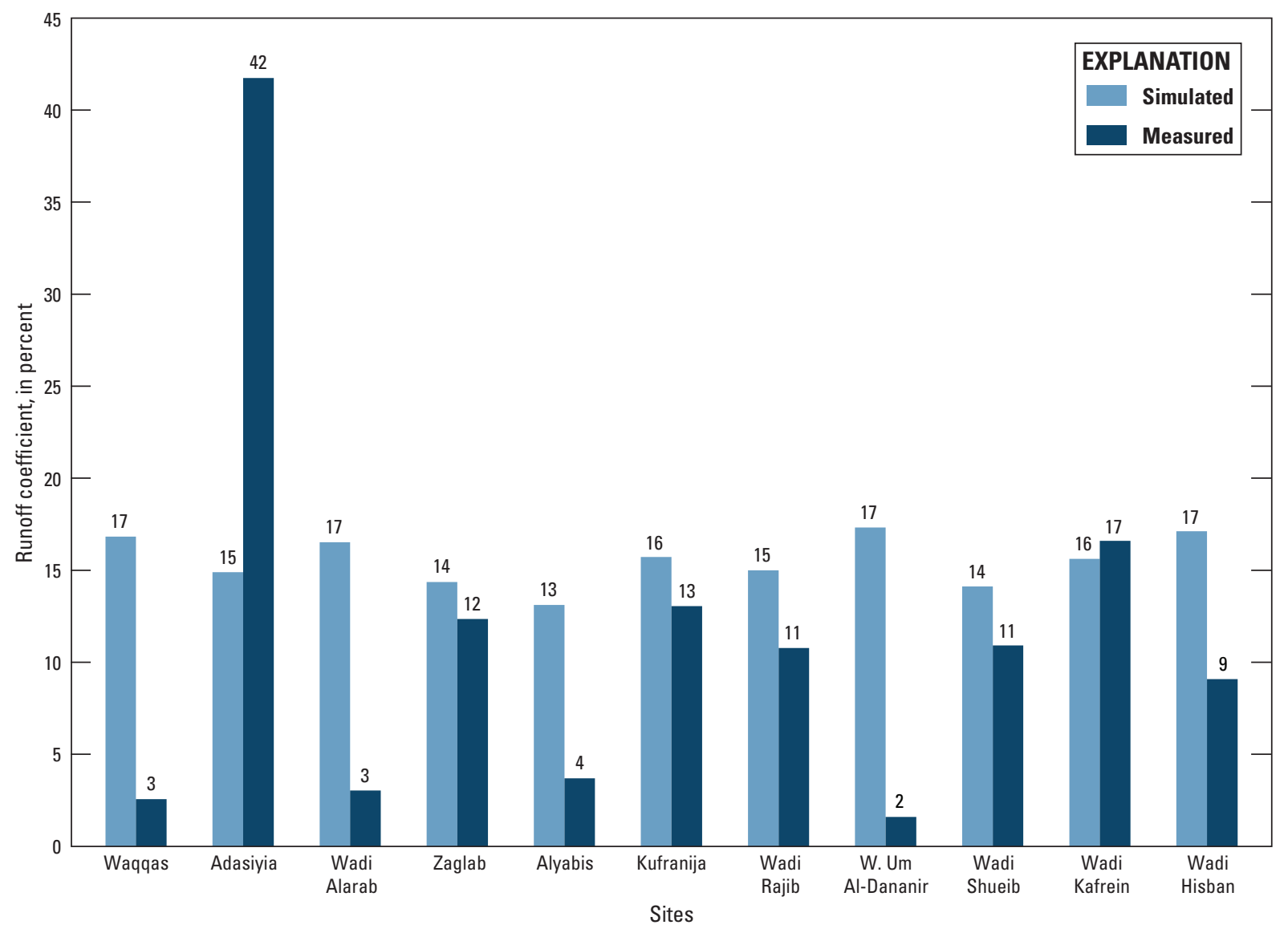

Figure 16. Simulated and measured runoff coefficient (runoff volume/precipitation volume, as percent) at streamflow measurement locations in the lower Jordan Valley, Jordan. 


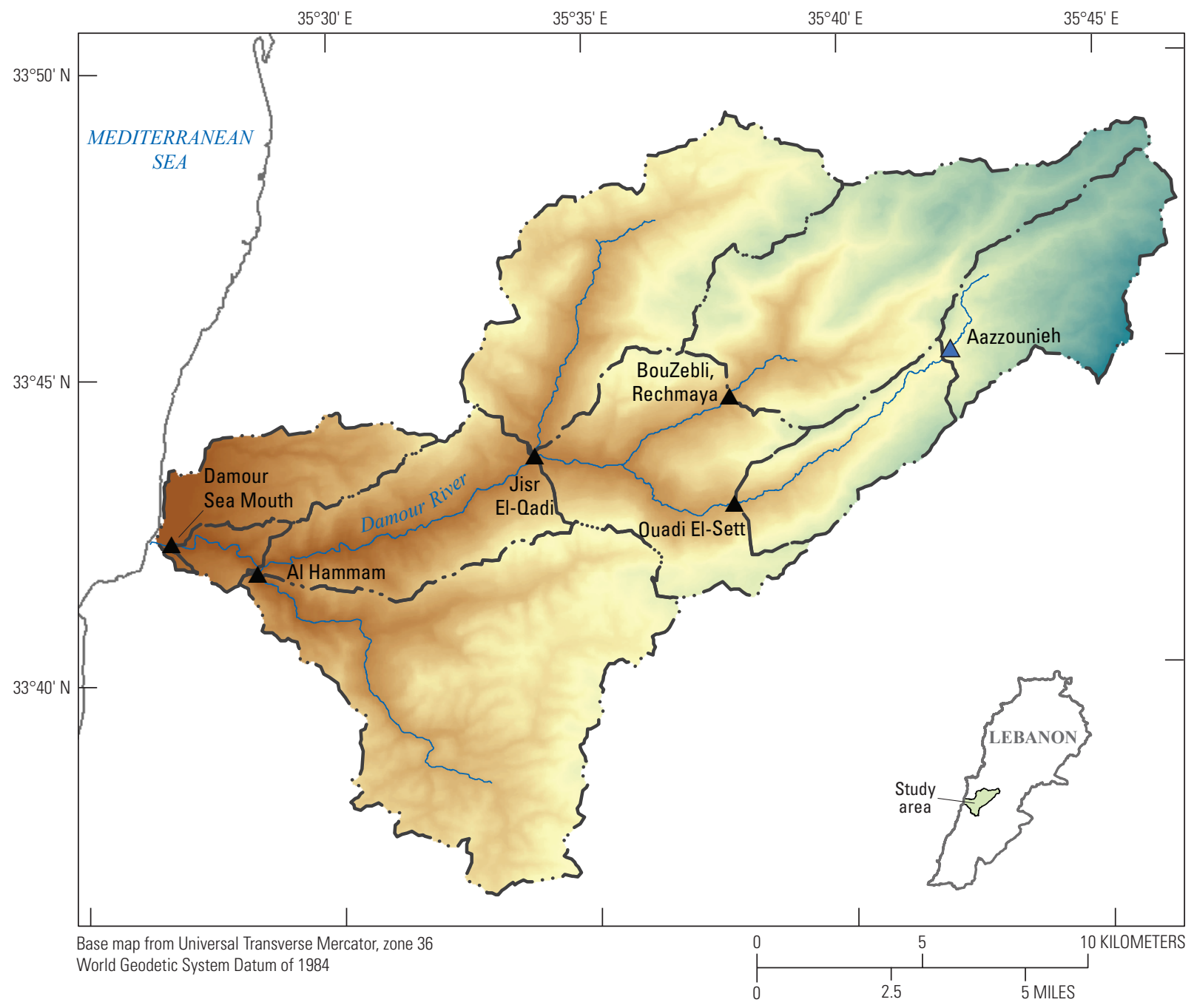

EXPLANATION

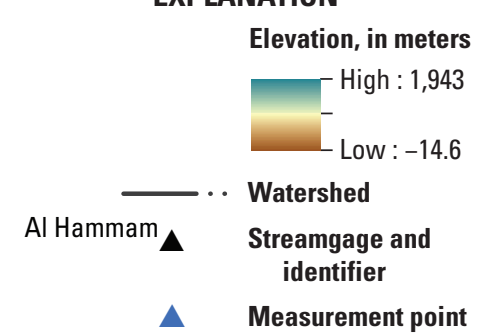

Figure 17. The Damour River basin, Lebanon, with topography, streamflow measurement locations, and corresponding subbasins for the runoff model (after Itani and others, 2021). 


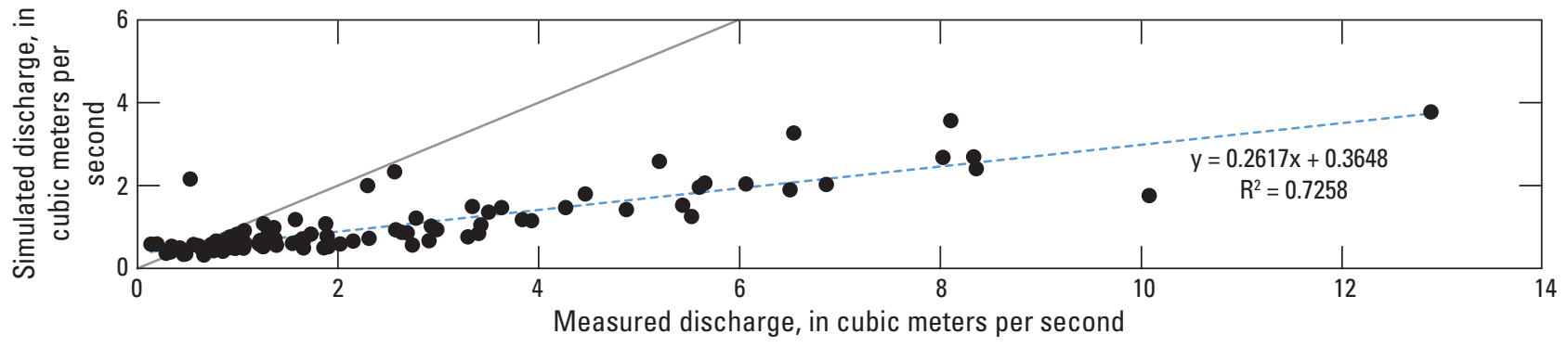

Figure 18. Simulated and measured streamflow at measurement locations in the Damour River Basin, Lebanon (after Itani and others, 2021). The identity (1:1) line and linear regression are also shown.

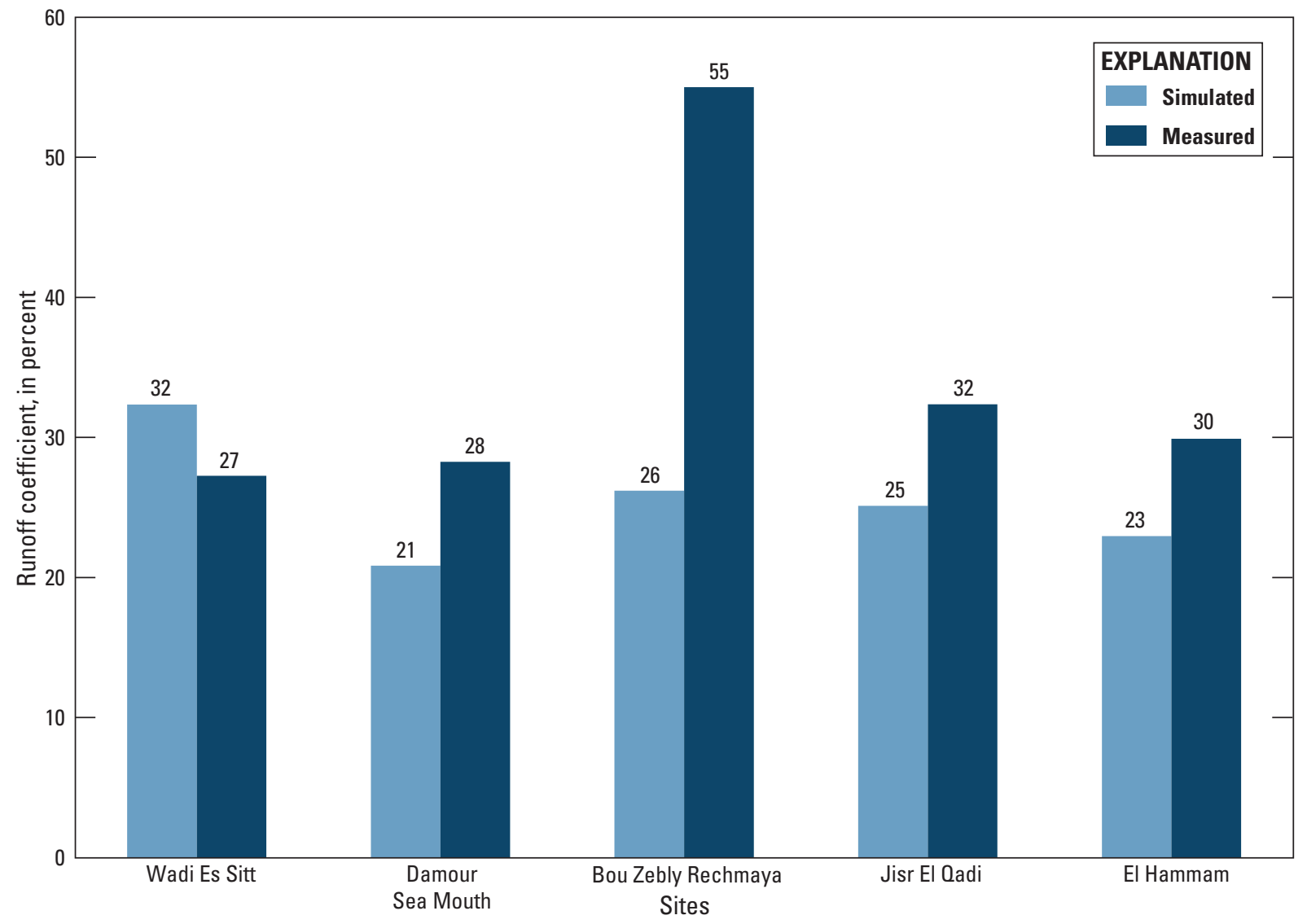

Figure 19. Simulated and measured runoff coefficient (runoff volume/precipitation volume, as percent) at streamflow measurement locations in the Damour River Basin, Lebanon (after Itani and others, 2021). 


\section{Suitability Mapping for Regional Screening}

\author{
By Michael van der Valk' ${ }^{1}$, Noura Hany ElHariry², \\ Galen Gorski ${ }^{3,4}$, and Daniel J. Goode ${ }^{4}$
}

\section{Introduction}

Gale (2005) extensively details many methods to recharge aquifers artificially. In short, it depends on both the geographic and geologic characteristics of the terrain and on the technique that one would like to use for recharge. For example, for deep infiltration by means of boreholes and wells that pump water into a deep aquifer, the main constraint is the suitability of the aquifer in terms of hydraulic conductivity, permeability, transmissivity, storage capacity, and water quality. Physical geography is much less important for deep infiltration; the same technique can be used regardless of terrain or geographical location.

In the case of superficial recharge - behind dams or in ponds or lakes - the physical geographic characteristics of the region under study are more important. For example, in a flat delta region with a shallow groundwater level, the permeability of the surface (soil type, geology), water availability (hydrology, meteorology), vegetation, and possibly even human factors such as population density, protection status of the land (natural reserves), and distance between water source and use locations should be taken into account. For a mapping exercise in Bangladesh, Shahinuzzaman and others (2021) use no less than 11 factors in an analytical hierarchy process to develop a map showing groundwater potential. In mountainous regions, different parameters than those used for flat areas are needed to define the suitability of an area. Similarly, the parameters that are important for

humid regions are different from those that are important for semiarid regions.

The principle of combining different datasets with geographic information - maps or map layers - goes back to the 1980s when the first primitive geographic information systems (GIS) were developed. Improvements in technology, including computer monitors with higher resolution and color, higher computing and data storage capacity, and a mouse, increased the development and use of geographic information systems (Burrough, 1986; Burrough and McDonnell, 1998). This included the combination of hydrological modeling aided

\footnotetext{
${ }^{1}$ Hydrology.NL.

${ }^{2}$ Arab Water Council.

${ }^{3}$ University of California at Santa Cruz.

${ }^{4}$ U.S. Geological Survey.
}

by GIS and remote sensing data (for example, Allewijn, 1990; Van der Valk, 1992, 1995).

In an inventory of GIS-based mapping methods for aquifer recharge used in 63 projects all over the world, Sallwey and others $(2019 a, b)$ show that as many as 21 different parameters have been used to identify potentially suitable areas. These often include overlapping parameters, such as slope, land use, geology, aquifer thickness, hydrological soils, soil type, geomorphology, drainage density, flow capacity, storage capacity, storage-flow capacity, precipitation, runoff, economy, impact assessment, hydrography, and the quality of groundwater and surface water (fig. 20). Sallwey and others (2019b) conclude that "to date, there is no common understanding on how to generate suitability maps," but also that "the purpose of suitability maps is still a matter of discussion." In fact, any research should start with this last question: why? They go on to state that "the advantage of such maps for water management plans lies within the spatial display through maps."

Beven (1993) questions whether a process that involves many parameters and a formalized decision chain with many steps (for example, an analytical hierarchy process) results in better maps than a simple decision process. For example, in their Manual on Artificial Recharge of Ground Water, the Central Ground Water Board (2007) states that a "base map, preferably on 1:50,000 scale showing all available geological, physiographical, hydrogeological and hydrological details along with land use, cropping pattern, and so forth is a prerequisite for the scientific planning." Although this is true, at this stage of this project we are merely doing an assessment of locations that might potentially be suitable for groundwater recharge.

The number and type of parameters that could be used to develop a suitability map depend on the type of MAR envisioned, the geology, and the physical geography including climate, among other possibilities Kazakis (2018). There is no single guideline as to what is good or what should be done. It has been noted, however, that there is a tendency to use as many parameters as available rather than looking at what is really required and expedient. In several cases, it is clear that more parameters have been used than would have been necessary to have a similar outcome. It was noted for a suitability study using seven parameters that 80 percent of the suitable locations could have been identified using only three parameters (C. Stefan, Technische Universität Dresden, Germany, written commun., 2021). The best method to identify suitable MAR sites will depend on the type of MAR, the geological and physical-geographical parameters of the area, and the availability of data. Sallwey and others (2019a) note that "areas that have been identified as suitable for MAR should be investigated with subsequent in-situ measurements to characterize the hydrology and hydrogeology of the site."

This project's objectives included (1) production of a regional map that shows suitability for MAR in the project region as a screening tool, and (2) illustration of the map-making methods. At the regional scale, consistent field datasets are not available and we relied on remote sensing data in order to 


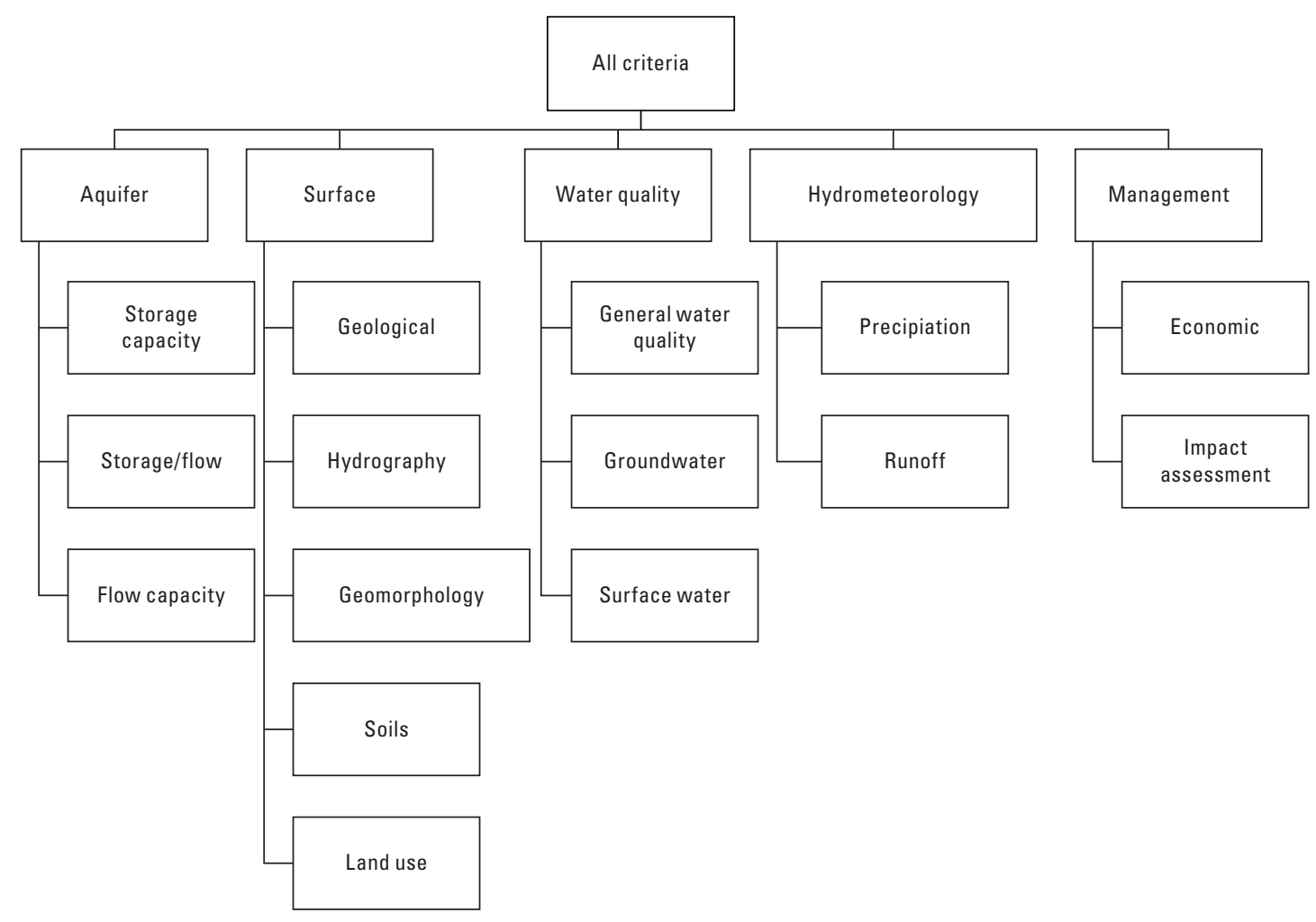

Figure 20. Example of grouping of criteria used in evaluated geographic information system-multicriteria decision analysis studies (after Sallwey and others, 2019a).

produce a screening map for MAR suitability. The options, in terms of useful remote sensing data that are consistent for the entire region, available for free, and that cover all of the area are limited ${ }^{1}$. Luckily, the pattern of the geologic and geographic characteristics of most, if not all, of the project area is such that with only two datasets a screening suitability map of the region could be produced.

The screening suitability maps were prepared using two geofactors, slope and runoff, based on two publicly available GIS data layers:

- A digital elevation model (DEM), from the Shuttle Radar Topography Mission (U.S. Geological Survey, 2017), with a raster size of about 30 meters (m), and

- A simulated average annual accumulated runoff (1984-2015) (see Regional Water Availability section; Senay and others, 2021).

Based on the DEM, slope was calculated following the algorithm provided by Burrough (1986) and Burrough and McDonnell (1998):

$$
S=\arctan \sqrt{\left(\frac{d z}{d x}\right)^{2}+\left(\frac{d z}{d y}\right)^{2}} * \frac{180}{\pi}
$$

where

$S \quad$ is the slope in degrees and

$d z / d x$ and $d z / d y$ are the slope in the east-west and north-south directions, respectively. Local (3 x 3 pixel) smoothing was applied to the raw slope at the $30-\mathrm{m}$ resolution to reduce chaos, noise, and singular spikes in the slope raster.

Alternative methods are available for how factors are combined to produce a map characterization of suitability. We illustrate two different approaches for combining two factors, slope and water availability, to produce a regional screening map. The first method used tabular classification and combined ranking of each combination of slope class and runoff class. The second applied the widely used Multi-Criteria Decision Analysis (MCDA; Malczewski and Rinner, 2015), which similarly uses classification of the factors, but which can easily incorporate any number of additional factors and formalizes the combined ranking. In any case, it is recommended to first select a MAR method, and only then start working on an analysis to find suitable locations for that MAR method.

\footnotetext{
${ }^{1}$ In the Aqueduct Water Risk Atlas of the World Resources Institute, our study area is captured in a few pixels with the same value, a water stress that is "extremely high." There is no differentiation between the high mountains of Lebanon $(>1,500 \mathrm{~mm} /$ year of precipitation) and the Jordanian Black Desert $(<200$ $\mathrm{mm} /$ year of precipitation) (World Resources Institute, 2021).
} 
Table 3. Classes and ranking used to produce a managed aquifer recharge (MAR) suitability map on the basis of slope and accumulated runoff.

\begin{tabular}{ccc}
\hline $\begin{array}{c}\text { Accumulated runoff (cubic } \\
\text { meters per year) }\end{array}$ & Slope (degrees) & Suitability ranking \\
\hline$<250,000$ & $\geq 8$ & 0 \\
$<250,000$ & 4 to $<8$ & 1 \\
$<250,000$ & 4 & 2 \\
$250,000-1,000,000$ & $\geq 8$ & 0 \\
$250,000-1,000,000$ & 4 to $<8$ & 1 \\
$250,000-1,000,000$ & $<4$ & 3 \\
$1,000,000-10,000,000$ & $\geq 8$ & 0 \\
$1,000,000-10,000,000$ & 4 to $<8$ & 1 \\
$1,000,000-10,000,000$ & $<4$ & 4 \\
$10,000,000-100,000,000$ & $\geq 8$ & 0 \\
$10,000,000-100,000,000$ & 4 to $<8$ & 1 \\
$10,000,000-100,000,000$ & $<4$ & 5 \\
$>100,000,000$ & $\geq 8$ & 0 \\
$>100,000,000$ & 4 to $<8$ & 1 \\
$>100,000,000$ & $<4$ & 6 \\
\hline
\end{tabular}

\section{Classification and Combined Ranking Method}

The first illustrative screening suitability map was prepared by classifying the two factors, slope and runoff, and then ranking each combination of the slope and runoff classes. Three classes were used for slope and five for runoff. Thus, there were $3 \times 5=15$ combinations, which were placed in 7 ranks, from 0 (unsuitable) to 6 (high suitability).

We first classified three levels of suitability for slope:

- Greater than 8 degrees - Unsuitable

- 4 to 8 degrees - Medium suitability

- Less than 4 degrees - High suitability.

A review of the literature indicates that a slope of 4 or 5 degrees appears to be a critical value above which the slopes are less suitable. We excluded locations with slopes greater than 8 degrees; clearly the mountain areas are not suitable for spreading basins owing to the land surface slope (fig. 21).

We arbitrarily chose five classes of runoff, but the number of classes could be changed. The same holds true for the class boundaries. Smaller runoff class ranges were chosen for lower runoff. The runoff in a stream was considered to be available for MAR within about $150 \mathrm{~m}$ of the stream. The individual $30-\mathrm{m}$ pixels representing streams were expanded by 5 pixels on each side such that the mapped streams have a width of about $330 \mathrm{~m}(150+150+30 \mathrm{~m})$. It is assumed that $150 \mathrm{~m}$ is an acceptable distance to obtain water from for a MAR project, and thus locations within this buffer are assigned the runoff suitability of the stream pixel. Note that the value of $150 \mathrm{~m}$ is arbitrary and that this value can be changed if needed.

Combinations of slope and runoff have been ranked in order to produce a regional screening suitability map (fig. 22). The assigned ranks of the combinations are shown in table 3 . We assume that water would need to be in sufficient quantity and would not be transported over long distances (Kurtzman and Guttman, 2020). When transport over long distances becomes an option then water availability becomes less of an issue. For example, in Lebanon, energy supply may be limited, and this would encourage water authorities to focus on areas close to rivers for MAR (Damaj, 2019). In addition to energy supply issues, the prevention of seawater intrusion is a major incentive for MAR projects in Lebanon (Prinz, 2016; Khadra, 2017; Saadeh and Wakim, 2017), for which deep recharge injection wells might be more effective than spreading basins at land surface.

\section{Multi-Criteria Decision Analysis Method}

A commonly used technique for mapping MAR suitability is the Multi-Criteria Decision Analysis (MCDA) (Malczewski and Rinner, 2015; also see the Web Tool and Lebanon Case Study sections of this report), which is often used for complex decisions related to disparate factors. The method 


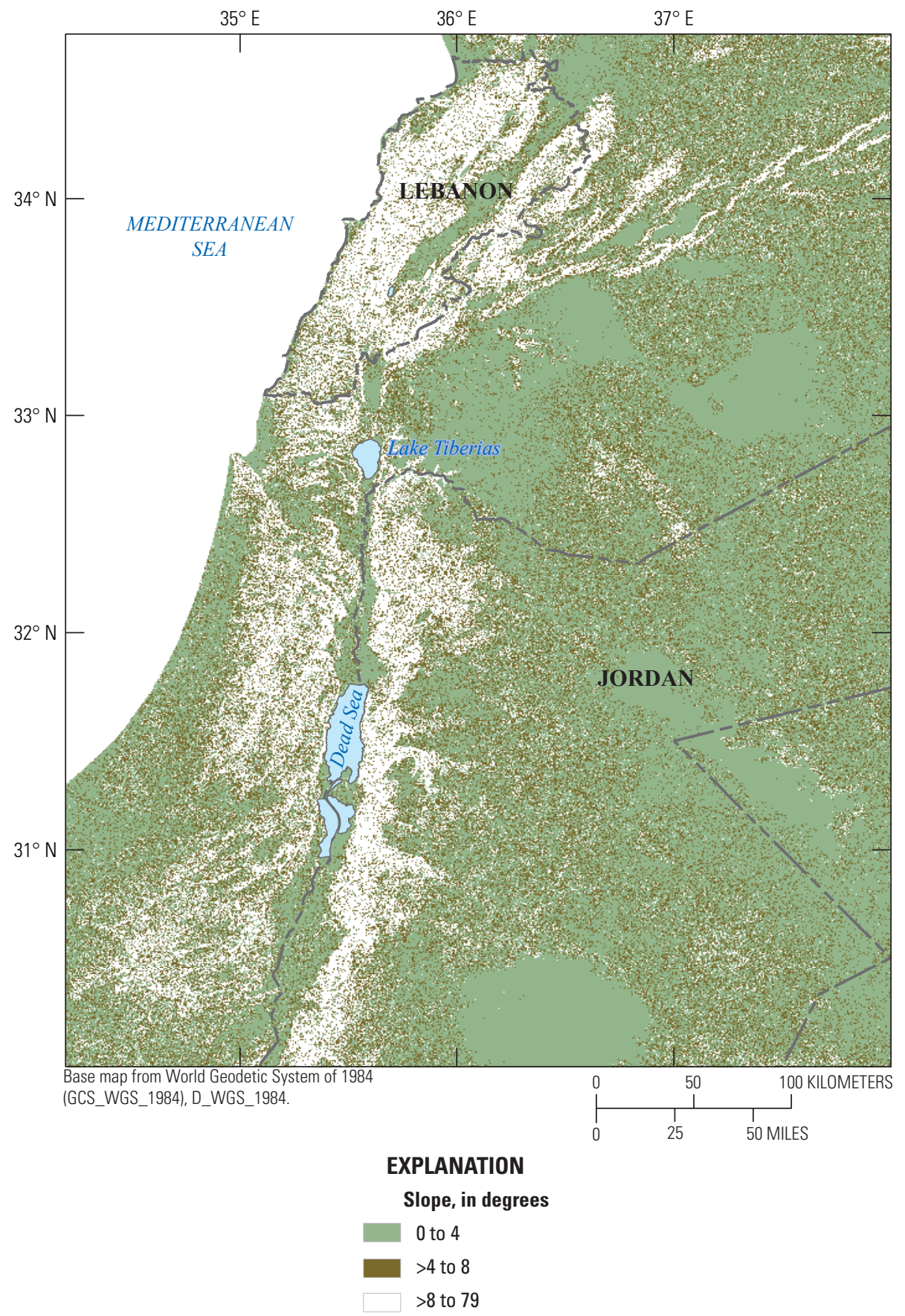

Figure 21. Land surface slope in Lebanon, Jordan, and surrounding areas, using $3 \times 3$ pixel smoothing of the 30 -meter raster data. 


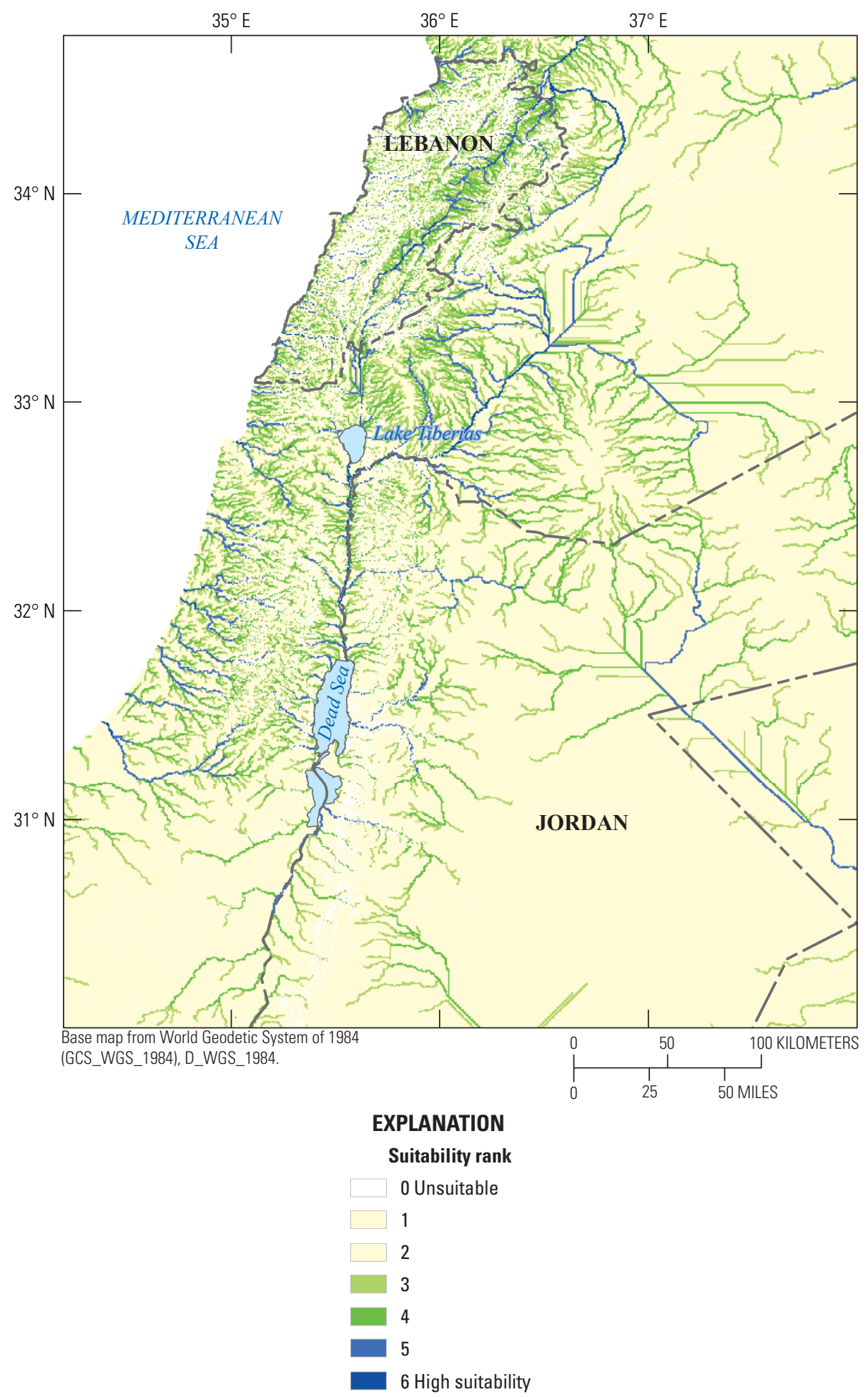

Figure 22. Regional screening suitability map in Lebanon, Jordan, and surrounding areas based on slope and water availability only, using the classification and combined ranking approach. 
remains highly subjective and relies on expert judgement, but the scoring and weighting of different factors is formalized such that it can be easily expanded and updated as additional data become available, factors are added, or conditions change such that scores and weights should be adjusted.

The same two factors, slope and runoff, were used for the MCDA map. Additional smoothing was applied to the slope by upscaling by a factor of 10 and then downscaling by the same factor to produce a smoothed raster of slope at the model 30-m resolution, herein referred to as the "resampled" slope. The slope classification used the same three classes, but a $0-100$ score for suitability was used, from 0 (unsuitable) to 100 (highly suitable). Furthermore, slope scores of 0 were excluded from further evaluation. Thus, the slope classes and scores were

- more than 8 degrees - excluded,

- 4 to 8 degrees -50 , and

- less than 4 degrees - 100.

The water availability classification was also modified for the MCDA map. We increased the distance from the stream by 33 pixels on each side of streams (pixels with high accumulated runoff), so that they became about $990+990+30=2,010$ $\mathrm{m}$ in width. This means that for MAR suitability, high storm runoff should be available from a stream within about $1 \mathrm{~km}$ distance of the MAR site.

As with the ranking method, we used five classes for runoff, but used a $0-100$ score for suitability from 0 (unsuitable) to 100 (highly suitable), and excluded the lowest runoff class:

- Less than 250,000 cubic meters per year ( $\mathrm{m}^{3} /$ year $)$ excluded

- $250,000-1,000,000 \mathrm{~m}^{3} /$ year - 25

- >1,000,000-10,000,000 m³/year - 50

- >10,000,000-100,000,000 m³/year - 75

- $>100,000,000 \mathrm{~m}^{3} / \mathrm{year}-100$

The categories and scores for runoff were subjective. The data could be reanalyzed in future work using the same algorithm but with easily changed category and score settings in the GIS program.

The last step in the MCDA is computing the overall suitability score as a weighted sum of all factors, which in this case are slope and runoff (fig. 23). If the weights for all factors add up to 1 , the suitability score will also be on a scale of $0-100$, with 100 being highly suitable for all factors. We chose weights of 0.8 for slope and 0.2 for runoff (table 4).

In summary, the main differences between the classification and combined ranking map were

- a resampled slope,
- runoff expansion within $990 \mathrm{~m}$ instead of $150 \mathrm{~m}$ of stream pixels,

- an excluded lowest runoff class, and the

- MCDA scoring and weighting method.

\section{Interpretation}

Despite the different methods used, the final regional screening suitability maps were similar and matched well with existing subjective judgement about the suitability for MAR in different areas. The main differences in the maps were a result of the wider buffer around streams and the exclusion of the lowest runoff class, rather than the method used. The maps also show high suitability around long drainages in eastern desert areas, but these were partly the result of artifacts in the model that generated the runoff by instantaneous accumulation alone, without simulation of more realistic streamflow processes.

Even though the maps are based on limited data (slope from a satellite-based digital elevation model and runoff from satellite-based precipitation data) the maps match well with earlier work by the University of Jordan on the Jordan Valley (for example, Salameh and Abdallat, 2020a) and by the American University of Beirut on the Damour River Basin (for example, Khadra, 2017; Itani and others, 2021). The Lebanon Case Study section of this report presents a more detailed application of the MCDA method with different criteria and more data - data that were not available for the large area of the regional screening map.

For effective recovery of recharged water, groundwater should not be at the surface and not too deep, therefore transition zones between mountains and flat areas would likely be most suitable (see Jordan Case Study section). Without using groundwater as an input parameter this is indeed what follows from the simple analyses based on only slope and runoff: many landscape features are connected.

\section{Web Tool for Simplified Ranking}

Although methods can vary widely, input datasets used to create recharge suitability maps are generally classified, weighted, and aggregated based on expert opinion, local conditions, or project goals. The decisions made at each step in the process can significantly affect the final suitability map in complex nonlinear ways that are difficult to discern without conducting formal sensitivity analyses. This can result in a lack of transparency, which may hinder understanding and adoption of recharge practices. Further, without a clear understanding of how input layers affect the final recharge suitability maps, it can be difficult to build intuition and understanding of the drivers of recharge suitability across landscapes. 


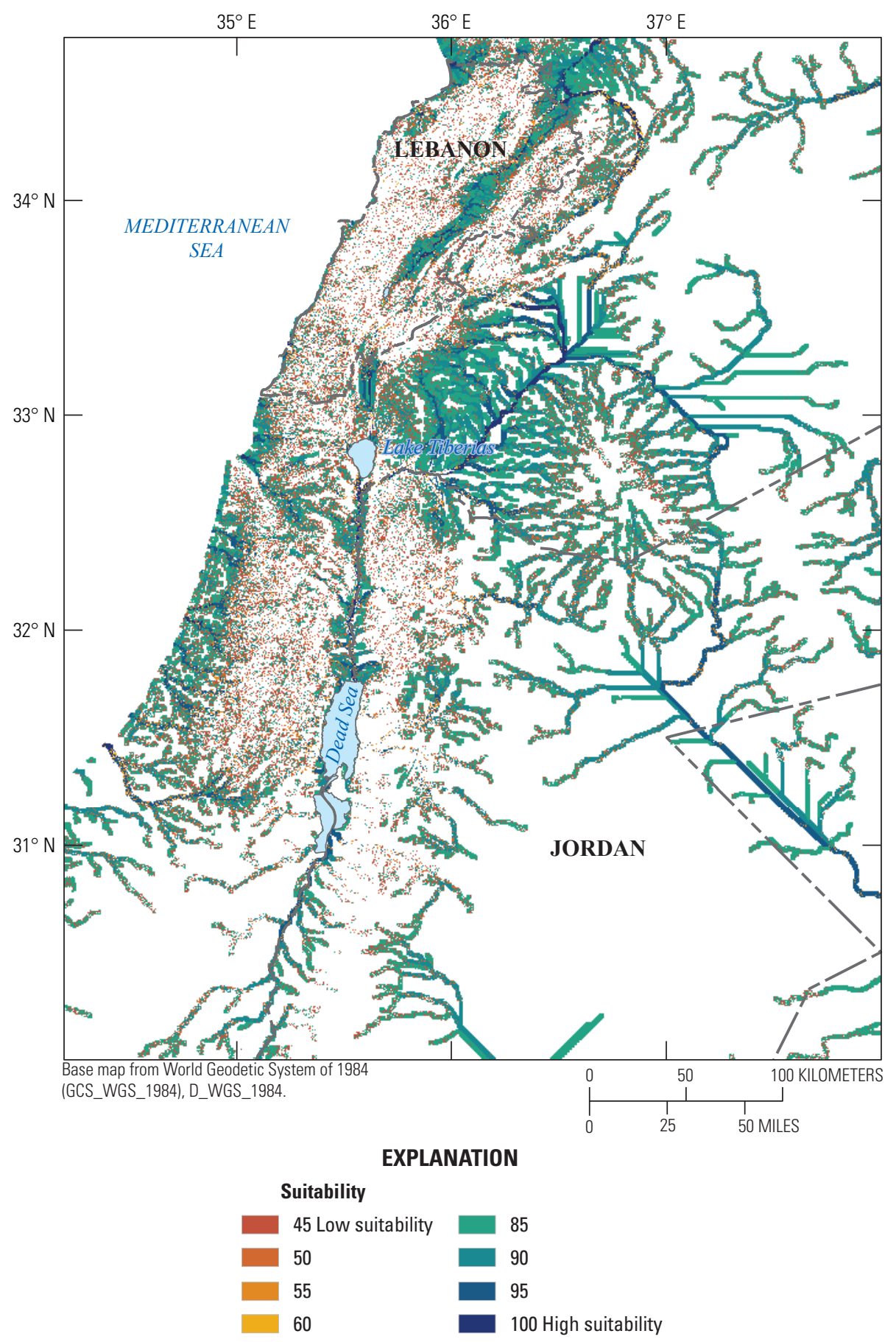

Figure 23. Managed aquifer recharge (MAR) suitability score in Lebanon, Jordan, and surrounding areas based on Multi-Criteria Decision Analysis (MCDA) using slope and runoff. 
To address these challenges, an open-source and interactive web application that allows users to classify, weight, and combine layers to produce suitability maps easily and transparently was developed for this project (Gorski and Van der Valk, 2019; Gorski, 2021). The user can choose how to make suitability classifications within each spatial layer, how to apply relative weights to different spatial layers, and observe how those changes affect the resulting suitability map and distribution of suitability scores across the landscape. The application has two preloaded spatial layers that describe modeled runoff and surface slope and uses a simplified version of suitability map creation compared to the methods described in this report. Values within each input layer are classified as having either "Good" or "Poor" suitability, based on a user-supplied threshold value chosen using interactive sliders. Those layers are then weighted based on user-supplied weights and linearly aggregated to create a final suitability map (fig. 24). The application is not meant as a substitute for more formal suitability mapping techniques, such as those deployed in this report, nor is the final suitability map from the application meant to match other suitability maps presented in this report. Rather, the web application is presented as a tool aimed at end-users and stakeholders as a way to increase transparency and process-understanding throughout the development of suitability mapping. We use example data from the Jordan Valley, a subset of our full project region to demonstrate the capabilities of the application (fig. 25). The web application was written in R (v 4.0.3) with shiny package (v 1.0.6). The application can be found at https:// ggorski.shinyapps.io/suitability_mapping_jordan_usgs_report and the code is archived with the CUAHSI Hydroshare online repository at https://www.hydroshare.org/resource/ e4c08ffba98746d7a8b3700723f24dcb/.

Table 4. Multi-Criteria Decision Analysis used to produce a managed aquifer recharge (MAR) suitability map on the basis of slope and accumulated runoff. Weights were 0.8 for slope and 0.2 for runoff.

[-, not applicable]

\begin{tabular}{ccccc}
\hline $\begin{array}{c}\text { Accumulated runoff (cubic } \\
\text { meters per year) }\end{array}$ & Runoff score & Slope (degrees) & Slope score & Suitability \\
\hline$<250,000$ & Excluded & $\geq 8$ & Excluded & - \\
$<250,000$ & Excluded & 4 to $<8$ & 50 & - \\
$<250,000$ & Excluded & $<4$ & 100 & - \\
$250,000-1,000,000$ & 25 & $\geq 8$ & Excluded & - \\
$250,000-1,000,000$ & 25 & 4 to $<8$ & 50 & 45 \\
$250,000-1,000,000$ & 25 & $<4$ & 100 & 85 \\
$1,000,000-10,000,000$ & 50 & $\geq 8$ & Excluded & - \\
$1,000,000-10,000,000$ & 50 & 4 to $<8$ & 50 & 50 \\
$1,000,000-10,000,000$ & 50 & $<4$ & 100 & 90 \\
$10,000,000-100,000,000$ & 75 & $\geq 8$ & Excluded & - \\
$10,000,000-100,000,000$ & 75 & 4 to $<8$ & 50 & 55 \\
$10,000,000-100,000,000$ & 75 & $<4$ & 100 & 95 \\
$>100,000,000$ & 100 & $\geq 8$ & Excluded & - \\
$>100,000,000$ & 100 & 4 to $<8$ & 50 & 60 \\
$>100,000,000$ & 100 & $<4$ & 100 & 100 \\
\hline
\end{tabular}




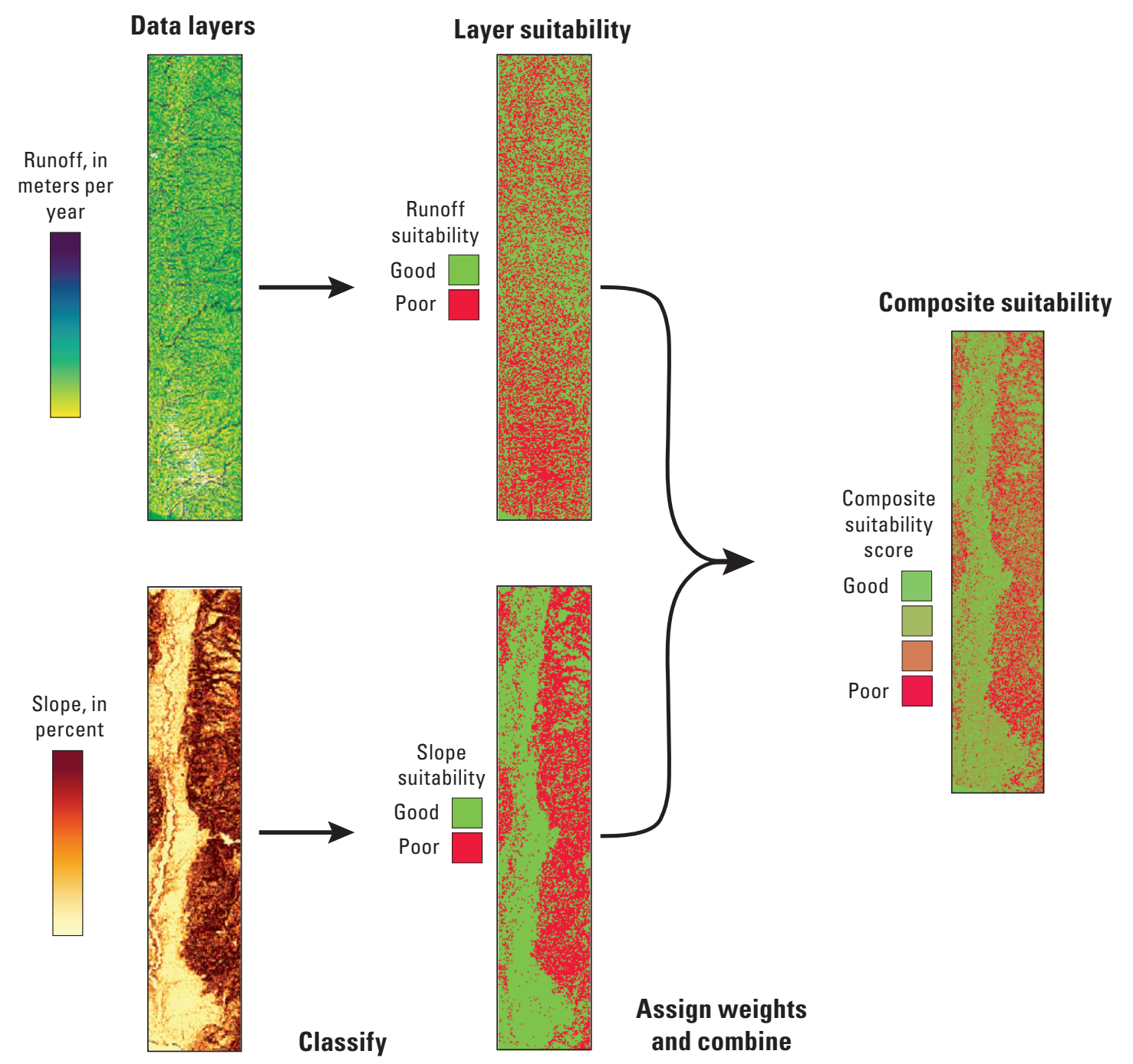

Figure 24. Conceptual diagram of the suitability map making process. Initial data layers are individually classified based on user-supplied thresholds for each layer, with a score of either 0 (poor) or 1 (good). Layer suitabilities are then weighted according to user-supplied weights and summed to create composite suitability maps. \%, percent; $\mathrm{mm} / \mathrm{yr}$, millimeters per year. 
$\boldsymbol{A}$

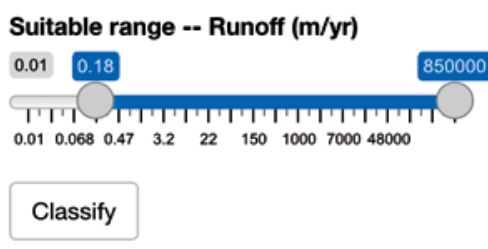

Classify
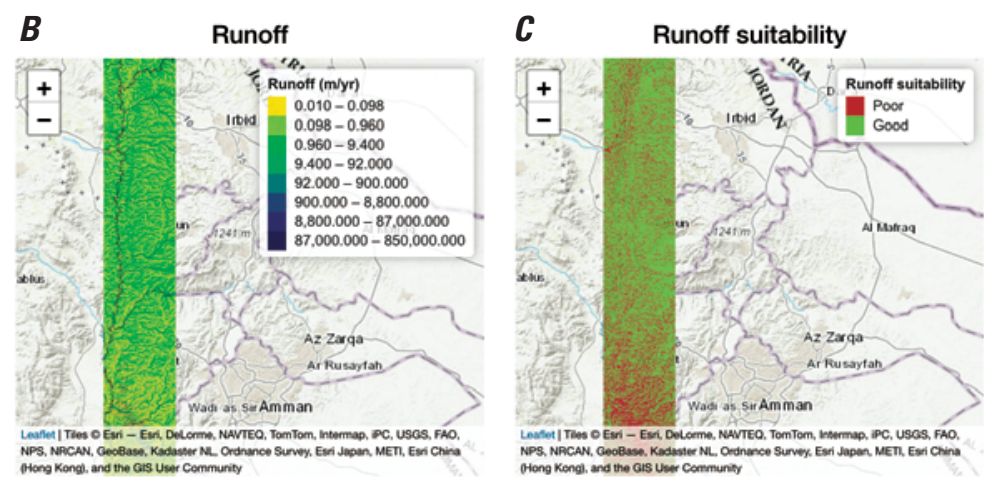

$E$

D

Factor weights

Runoff weight

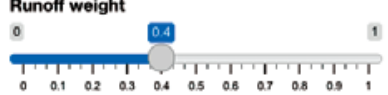

Slope weight

0

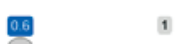

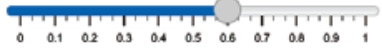

Sum of weights $=1$

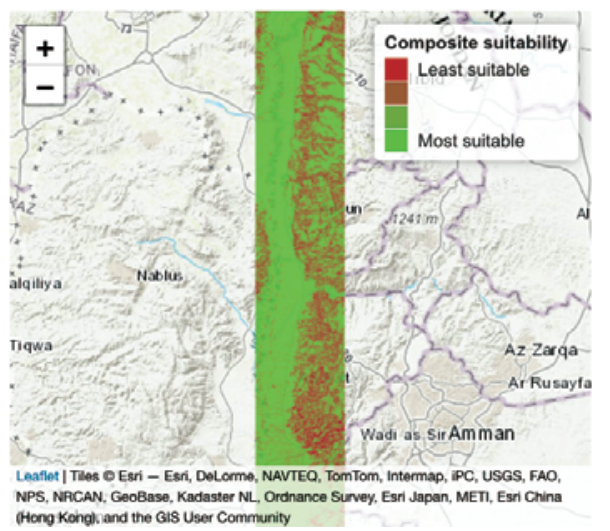

Figure 25. Screenshot of the web application. Users can view manipulate the thresholds for suitability in each layer using a slider $(A)$ and view how the suitability layer $(B)$ gets classified into "Poor" and "Good" suitability $(C)$. After the layers are classified, the user can manipulate the weights assigned to the layers using relative weight sliders $(D)$ to generate a composite suitability map $(E)$. All maps update in response to input, so that the user can see how choices affect the final suitability map in real time. 


\section{Jordan Case Study}

\author{
By Elias M. Salameh', Ghaida Abdallat', Marwan \\ Alraggad², Michael van der Valk3 , and Daniel J. \\ Goode $^{4}$
}

\section{Introduction}

Jordan has one of the world's lowest sustainable waterresources availability, relative to the country's water demand. Hlavaty (2018) ranked Jordan as the third "most water-poor" country in the world, when further accounting for each country's per capita economic resources available to mitigate shortages. According to the U.S. Agency for International Development (2020),

Jordan is one of the most water-scarce countries in the world. The country's renewable water supply currently only meets about half of the population's water demands, with groundwater being used twice as quickly as it can be recharged. A high rate of population growth and the influx of refugees from regional conflicts are putting additional strain on an already diminished water supply. Safe drinking water and proper sanitation services are fundamental to the health and wellbeing of the people of Jordan, and water is a central component of food production and economic growth. Sustainable and inclusive access to water is critical for the country's long-term stability and prosperity.

Jordan's climate is arid to semiarid, and is becoming even more arid with climate change (Rahman and others, 2015). Transboundary surface water resources have been dramatically reduced by increased withdrawals by upstream riparian users (Avisse and others, 2020). Per capita water availability has been predicted to decline by about 50 percent by the turn of the century (Yoon and others, 2021).

The growing water demand in Jordan has been met by capturing most flood runoff in dams, and by removing groundwater from aquifer storage, causing rapid groundwater level declines (Goode and others, 2013; Salameh and others, 2019 b). Groundwater salinity is also increasing in some wells, especially in regional discharge areas, as water levels drop (Goode and others, 2013). Continued water level declines are

\footnotetext{
${ }^{1}$ National Center for Research and Development (Jordan).

${ }^{2}$ University of Jordan, and Inter-Islamic Network on Water Resources Development and Management.

${ }^{3}$ Hydrology.NL.

${ }^{4}$ U.S. Geological Survey.
}

projected to dramatically affect farmer profits as groundwater pumping costs increase (Rosenberg and Peralta, 2012).

Artificial recharge was identified as an important method to improve water supply security and facilitate water reuse in Jordan as part of national integrated water resources management (Ministry of Water and Irrigation, 2009, 2016). Salameh and others (2019a) describe existing and proposed (but not yet implemented) managed aquifer recharge (MAR) projects in Jordan. Edworthy (2001) reviewed existing artificial recharge practices and possible water supply improvements from expansion in the Jordan Valley and other areas. Although not constructed for MAR, Jordan's Wala Dam has functioned as a MAR dam since 2002 (Salameh and others, 2019a; Xanke and others, 2015), and provides drinking water for major cities in Jordan through groundwater withdrawals from the recharged aquifer. Al-Assa'd and Abdulla (2010) evaluated alternative water management changes in Jordan that included MAR in combination with reductions in groundwater withdrawals. Alraggad and Jasem (2010) mapped areas of the Azraq Basin in central Jordan as suitable for MAR.

Abdallat and others (2020) proposed small dams for MAR in the Wadi Shueib and Wadi Kafrain basins upstream of the Jordan Valley study area in this report. Existing dams in those basins are contaminated by wastewater treatment plant (WWTP) discharges. Proposed dams would capture upstream uncontaminated streamflow in tributaries affected by WWTP discharges. The average annual runoff that would be captured by each dam was estimated to be from 108,000 to 510,000 cubic meters per year.

As part of the cooperative project that produced this report, a case study of MAR suitability in the Lower Jordan River Valley in Jordan was conducted by researchers at the National Center for Research and Development, with contributions from the University of Jordan and Inter-Islamic Network on Water Resources Development and Management, and from Hydrology.NL. Methods and results presented in this section are drawn primarily from a study area report by Salameh and Abdallat (2020b), and from journal articles by Salameh and others (2019a) and Salameh and Abdallat (2020a).

Salameh and others (2019a, b) review considerations for successful development of MAR in Jordan, as an example for MENA and other arid-region applications. They include not just hydrologic, geologic, and other technical considerations (fig. 26), but socioeconomic factors such as local acceptance and the potential value of improved water availability to stakeholders as well (table 5).

\section{The Lower Jordan Valley}

The potential of MAR was investigated in the lower Jordan Valley area (fig. 27). In the semiarid Jordan Valley area, with potential evaporation rates of 2,300-2,400 millimeters per year $(\mathrm{mm} / \mathrm{yr})$ and generally level topography, the water stored in surface reservoirs such as weirs and dams is subject 


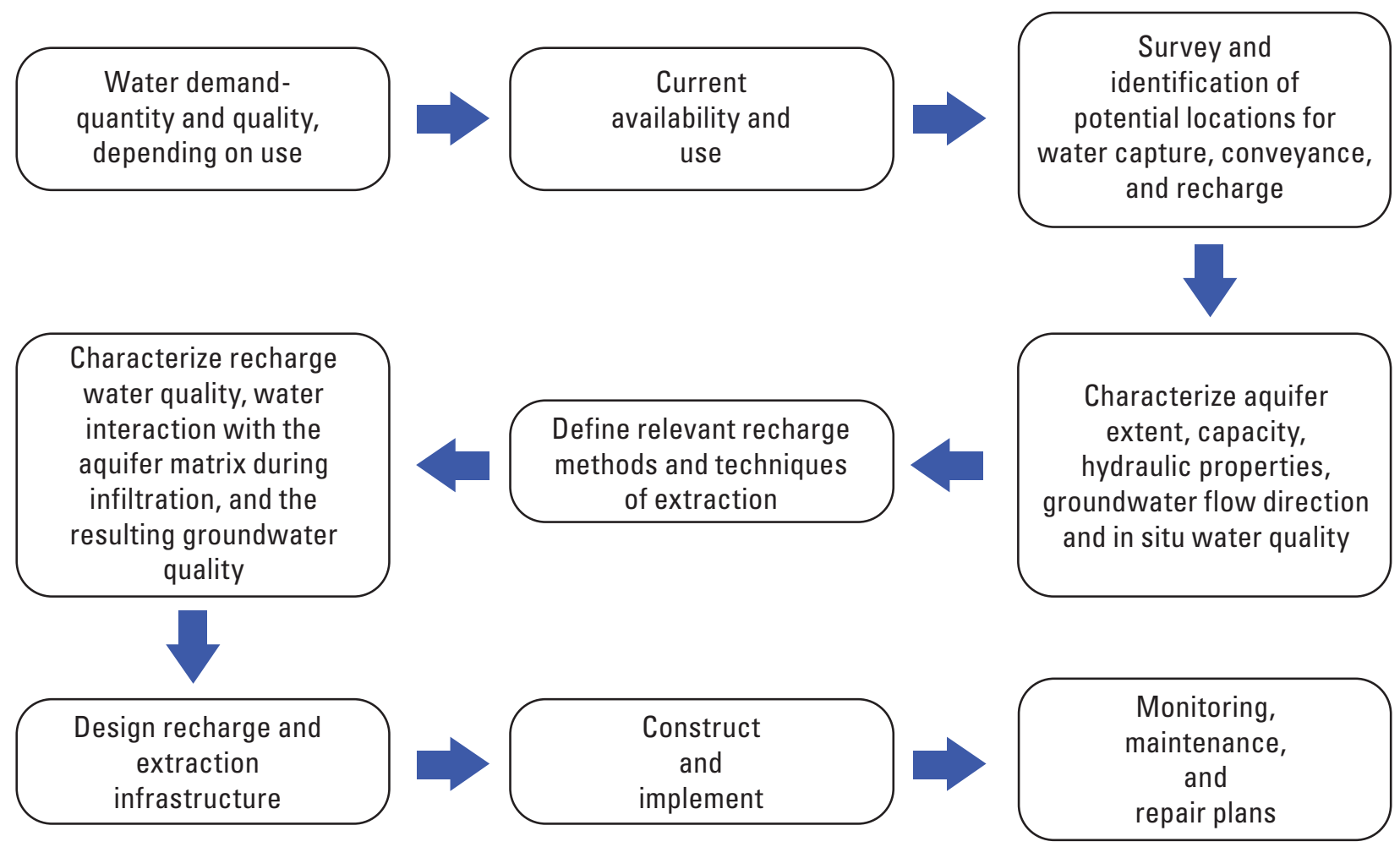

Figure 26. Flow chart of general design and development stages for managed aquifer recharge (after Salameh and others, 2019a).

to high evaporation, eutrophication, and pollution, rendering such storage impractical (Salameh and Abdallat, 2020b). Recent alluvial sediments that cover the Lower Jordan Valley area and extend from the foothills in the east to the Jordan River in the west, can be used as alternative natural subsurface water storage facilities. On the basis of geologic, topographic, hydrologic, hydrogeologic, geophysical, and borehole information, this study illustrates the potential for MAR along the eastern Lower Jordan Valley area and ranks the suitability of selected areas. In addition, the capacities of aquifers to accommodate water are calculated, and the geochemical characteristics of potential recharge water and aquifer water are analyzed.

The need for, and the conditions of, successful MAR projects and their relevance to the prevailing circumstances in Jordan, focusing on the lower Jordan Valley, are summarized by Salameh and others (2019a). MAR has been identified as a suitable water-resources management option for improving water security in the Jordan Valley area by

- Storing winter runoff for agricultural use in other seasons,

- Mitigating saltwater intrusion, and

- Improving the quality of the source water by in situ treatment.

Conditions in the lower Jordan Valley that encourage the use of MAR include (Salameh and others, 2019a)
- Unmet local water demand,

- Currently unused winter runoff,

- Aquifer permeability sufficient for infiltration,

- Aquifer storage capacity above the water table,

- Areas of low land-surface slope for spreading basins, and

- Source water quality that can be improved by natural treatment during recharge.

The lower Jordan Valley is a relatively flat flood plain that extends from Lake Tiberias in the north to the Dead Sea in the south. The overall valley length is $105 \mathrm{~km}$ and the width ranges from 4 to $30 \mathrm{~km}$. The main features of the valley area are the relatively flat terraces on both sides of the Jordan River, which constitutes what is on the eastern side called "Ghor" (fig. 28). During the Holocene, the Jordan River cut a meandering course as much as 500-m wide, locally called "Zoor," 10 to $30 \mathrm{~m}$ below the surrounding Ghor (fig. 28). The meandering Jordan River itself has a length of $217 \mathrm{~km}$. The rift basin valley is bordered by high, steep mountains with differences in elevations between the valley floor and the surrounding mountains of 1,000 to $1,500 \mathrm{~m}$. 
Table 5. Critical factors in designing and implementing managed aquifer recharge (MAR) in Jordan (after Salameh and others, 2019a).

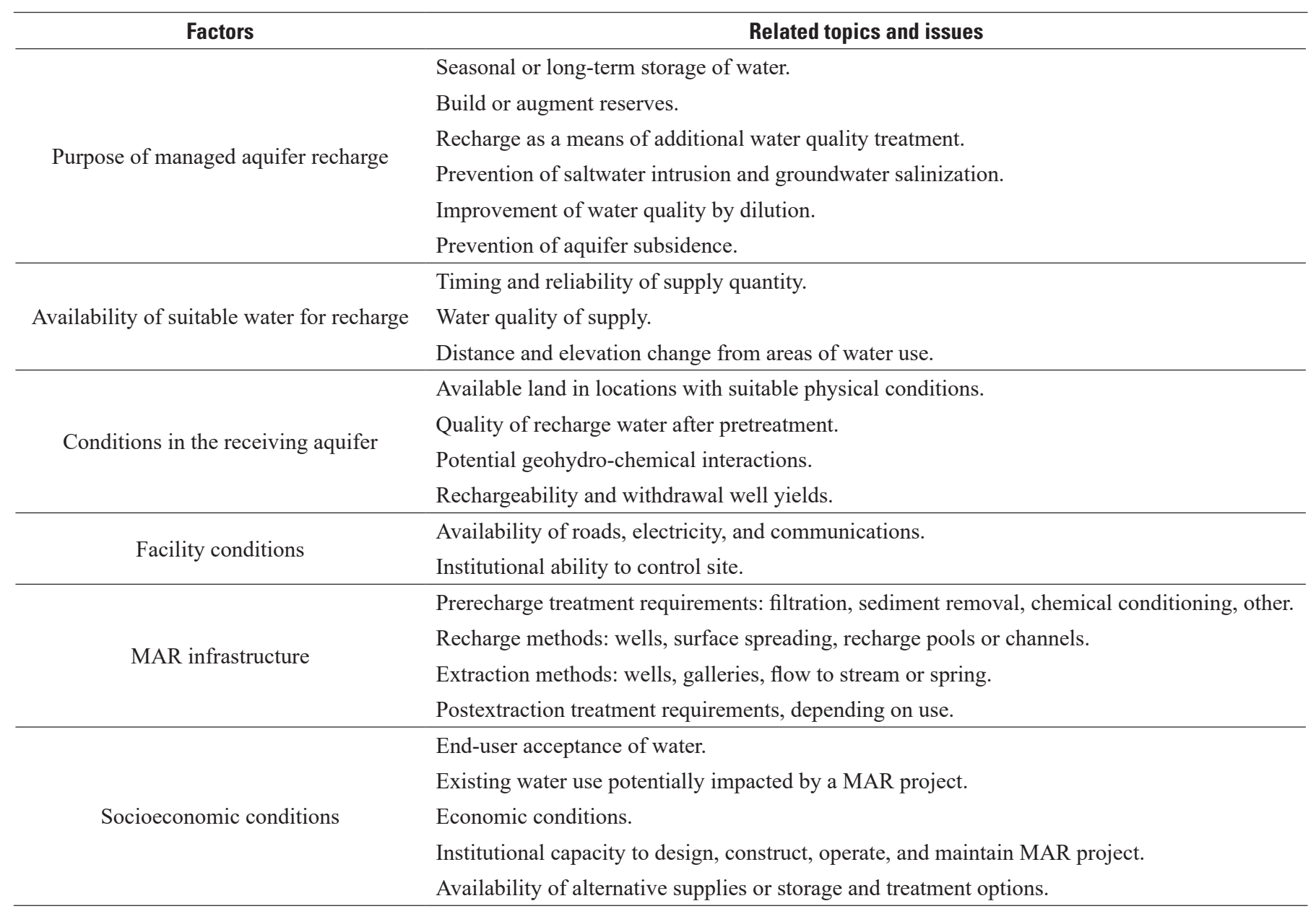

\section{Geology}

The surficial deposits of the lower Jordan River valley floor consist mainly of unconsolidated alluvial sediments of gravel, sand, shale, marl, and clay. In addition, fine salty marls that precipitated from the precursors of the present Dead Sea are found in the form of extensive deposits and lenses, especially in the southern and western parts of the valley at the slopes to the Zoor (Bender, 1968, 1975; Horowitz, 1979).

The surface geology, shown in figure 29, illustrates the older geological formations overlain by more recent deposits along the Dead Sea transform fault system that underlies the lower Jordan Valley from the Dead Sea to Lake Tiberias, generally parallel to the lower Jordan River. Relevant information about the escarpment foothills formations, lithology, thicknesses, and hydrogeology can be found in appendix 2 , table 2.1.

Recent unconsolidated sediments of the Jordan Valley are generally of Quaternary age and are underlain by rocks of Triassic to latest Holocene ages. Along the escarpment, rocks ranging in age from Triassic to latest Holocene crop out with their western extensions covered by the more recent alluvial deposits, the most recent being fans deposited where steep wadis intersect the valley floor. The sediments of relevance to the present study are of lower Pleistocene and younger ages and are subdivided into several formations (Salameh and Abdallat, 2020a, b).

\section{Ghor El Kattar and Shagure Conglomerates}

This formation consists of well cemented conglomerates with low porosities and permeabilities. It was deposited in the Jordan Valley floor, accompanied by faulting and the formation of the depression along the Jordan Valley. Ghor el Kattar sediments cover bedrock of different ages at the foothills of the Jordan Valley. The overall thickness may reach $350 \mathrm{~m}$ (table 6).

\section{Abu Habil, Kufranja, and Samra Formations}

An angular unconformity separates the overlying Abu Habil Formation from the Ghor El Kattar and Shagure Conglomerates. The Abu Habil Formation consists of clastic 


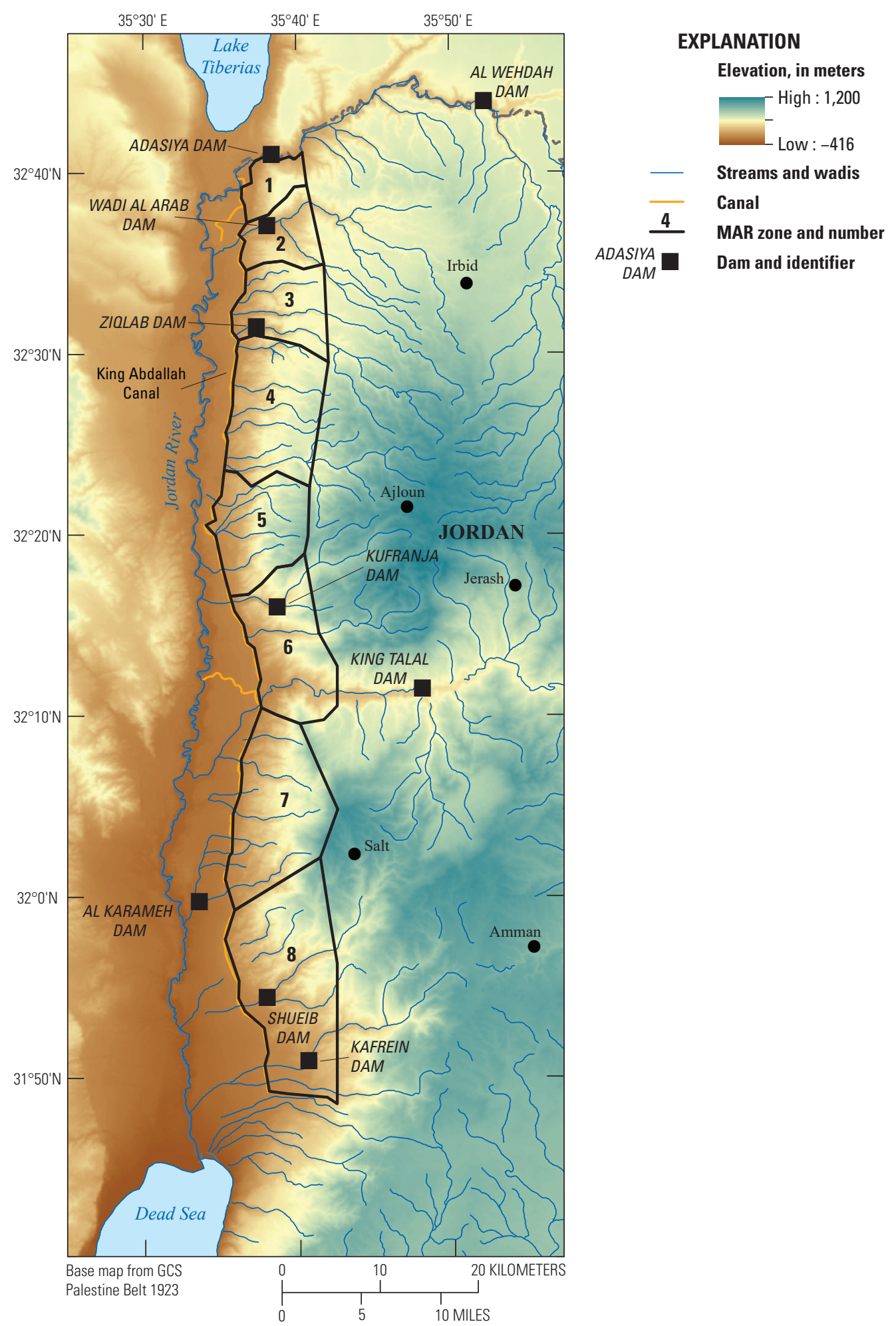

Figure 27. Map of study area in the lower Jordan Valley, Jordan, showing topography, hydrologic features, and numbered zones evaluated for managed aquifer recharge (MAR) suitability (after Salameh and Abdallat, 2020a, b). 
Table 6. Surficial formations in the Jordan Valley area (after Salameh and Abdallat, 2020a, b; Bender, 1968, 1975).

\begin{tabular}{cc}
\hline Formation & Thickness, in meters \\
\hline Recent alluvial fans & 0 to 100 \\
Lisan & 40 to a few hundred \\
Samra & 35 \\
Kufranja & 100 \\
Abu Habil & 100 \\
Ghor El Kattar & \\
and Shagure & About 350 \\
Conglomerates & \\
\hline
\end{tabular}

sediments with a total thickness of about $100 \mathrm{~m}$ and its deposition is related to tectonic activity along the Jordan Rift Valley. The Kufranja Formation mainly consists of conglomerates with a thickness of about $100 \mathrm{~m}$ and in places overlies the Abu Habil Formation. The Samra Formation consists of fineto coarse-grained clastics that cover areas within the Zoor. The groundwater within these formations is generally saline, except in the foothills of the mountains, where some fresh water can be found resulting from lateral flows that originate as runoff from the escarpment.

\section{Lisan Formation}

The Lisan Formation was deposited in Lisan Lake, which occupied the Jordan Valley area from about 80,000 years ago until the end of the Pleistocene and extended from Lake Tiberias in the north to about $45 \mathrm{~km}$ to the south of the south shore of the Dead Sea (Bender, 1968, 1975). The formation consists of very thin-bedded marls a few millimeters in thickness, with a total thickness ranging from 40 to more than a few hundred meters. In the southern half of the lower Jordan Valley and to the south of the Dead Sea, the deposit is highly gypsiferous, its salt content is high, and its groundwater is saline. Old alluvial fans containing fresh water inter-finger with the Lisan marls. The primary permeability of the formation is low but its secondary permeability along fractures and dissolution channels is high.

\section{Recent Alluvial Fans}

The recent alluvial deposits of Pleistocene and Holocene ages cover all older Quaternary deposits and have been deposited by the different rivers and wadis at their entrance into the lower Jordan River valley from its east side. These alluvial fans consist of gravels at their apexes and silt and fine sands at their toes near the Jordan River. Correspondingly, porosity and permeability are high in the gravels at the apexes but decrease towards the river. The thickness of these alluvial fans, as encountered by drilling and geoelectric soundings (Salameh and Abdallat, 2020a), may reach $100 \mathrm{~m}$ at the apexes, and thin out towards the toes. Slope debris, which originates from mass wasting at the escarpment foothills, interfinger and overlap these fans.

The major structural element that has impacted the configuration of recent deposits in the lower Jordan Valley is the Dead Sea transform fault system, which trends north-south parallel to the Jordan Valley and along which sinistral strikeslip movement has been taking place since the early Pleistocene (Bandel and Salameh, 2013). This fault transfers the Holocene sediments of the valley in a type of flower structure, which runs along the central valley in the southern part of the lower Jordan Valley and at the foothills of the eastern mountains in the northern part. The strike-slip sinistral movement along the northern part has resulted in the gradual separation of the alluvial fans and slope debris from their source wadis and mountains. This movement exposes the alluvial sediments to erosional and depositional processes that make the recognition and mapping of the ancient alluvial deposits by use of

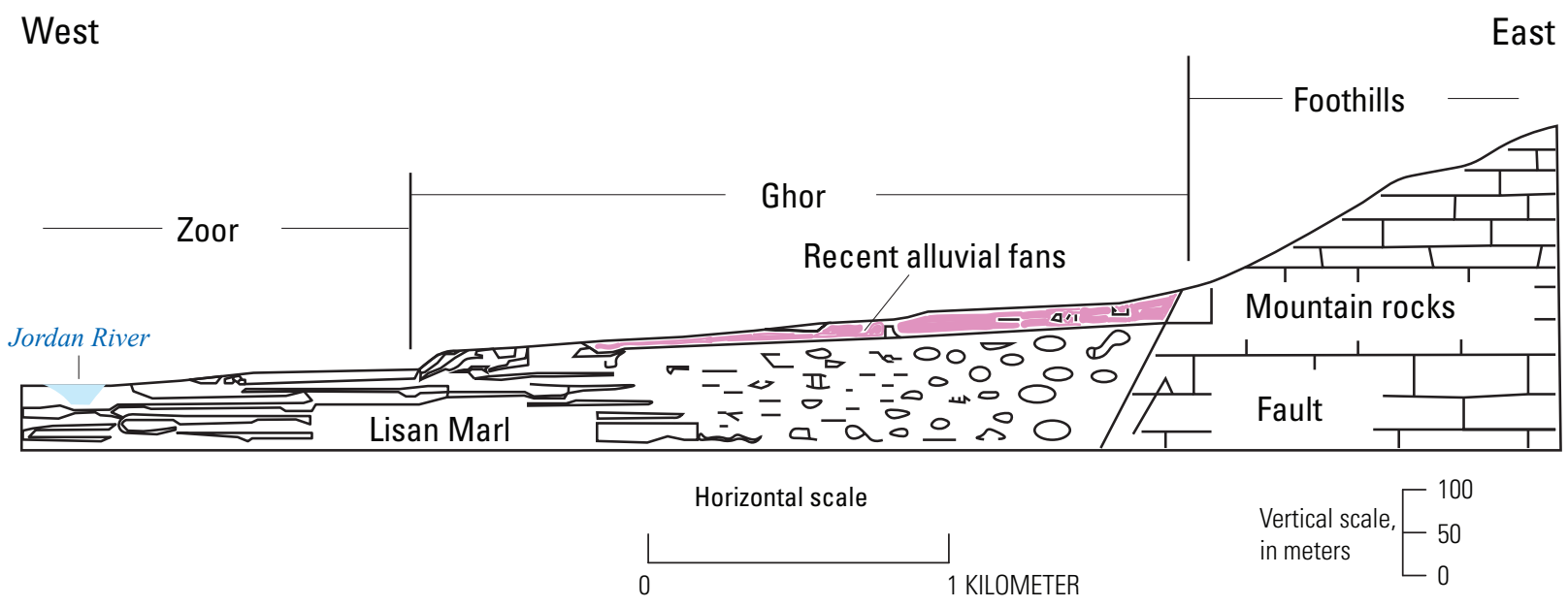

Figure 28. Schematic east-west cross section showing topography and surficial geology of the lower Jordan Valley, Jordan, including sediment source rocks in the eastern foothills and recent alluvial fans on the valley margin (after Salameh and Abdallat, 2020a, b). 


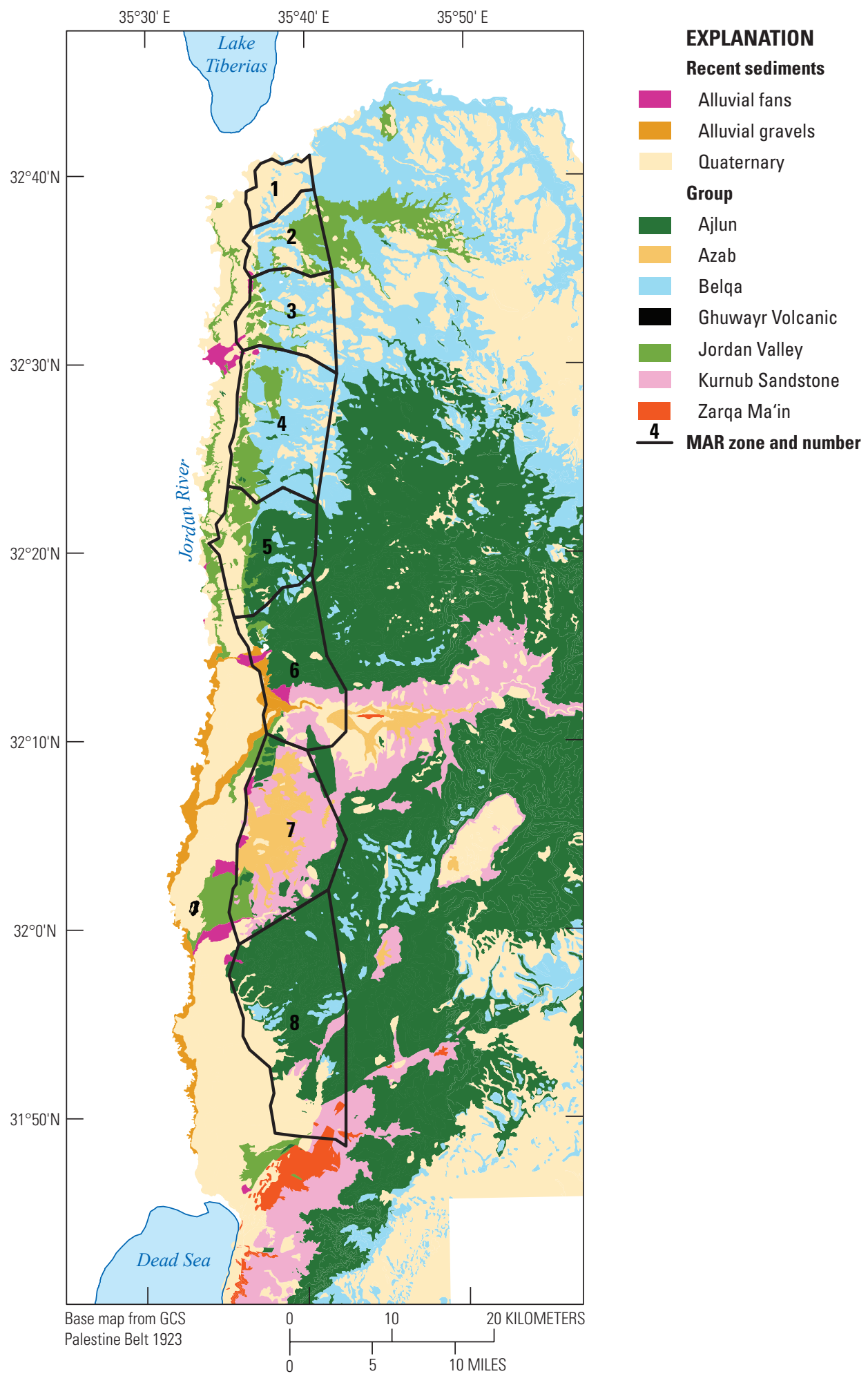

Figure 29. Surface geology of the lower Jordan Valley and northwest Jordan (after Salameh and Abdallat, 2020a, b; data from Natural Resources Authority, Jordan, written commun., 2017). 
conventional field methods very difficult. Indirect methods, geophysics, water balances, and drilling could be useful in identifying suitable sites for MAR.

\section{Climate}

Owing to its position of about $200-400 \mathrm{~m}$ below sea level, the lower Jordan River valley area has a unique climate, differing from the climate of the surrounding mountains in the east and west. The mean maximum monthly temperature in January (winter) is $31.5^{\circ} \mathrm{C}$, and the mean maximum monthly temperature in summer is $38.8^{\circ} \mathrm{C}$ (Jordan Department of Meteorology, Ministry of Transport, written commun., 2010). The highest ever recorded temperature is $52^{\circ} \mathrm{C}$. Winter temperatures during the night may even reach the freezing point. In the northern part of the valley, the average temperature is $1.8^{\circ} \mathrm{C}$ less than that in the southern part, with the highest recorded temperature of $51.2{ }^{\circ} \mathrm{C}$ and the lowest of $-2{ }^{\circ} \mathrm{C}$.

The relative humidity is very low in the southern part of the valley, with a long-term daily mean of 64 percent in the coldest period of the year (January-February), and a low of 27 percent in the hottest summer months at midday (Salameh and Abdallat, 2020b). In the northern part of the valley, the humidity ranges from 30 percent during hot summer days to 70 percent in the winter.

Rain generally falls from October to May, with a concentration from December to March (Salameh and Abdallat, 2020b). The northern Jordan Valley area receives an average amount of precipitation of about $400-500 \mathrm{~mm} / \mathrm{yr}$, whereas the southern area receives less than $200 \mathrm{~mm} / \mathrm{yr}$ (fig. 30). In dry years, the amount of precipitation in the northern part reaches only $200 \mathrm{~mm} / \mathrm{yr}$, whereas at the shores of the Dead Sea it decreases to merely $40 \mathrm{~mm} / \mathrm{yr}$. In wet years, precipitation may reach $650 \mathrm{~mm} / \mathrm{yr}$ in the north and $250 \mathrm{~mm} / \mathrm{yr}$ in the south. Snow falls very infrequently in the northernmost part of the valley.

\section{Water Resources}

\section{Surface Water}

As a result of its gentle slope, low rainfall, and highpermeability soils, the Jordan Valley area produces almost no runoff from precipitation falling over its southern part (Salameh and Abdallat, 2020a, b). In the northern part, runoff is very limited and negligible in terms of harvesting. The eastern Jordan River tributary drainage basins extend into the highlands and bring surface runoff into the valley. Average streamflow discharge values are given in table 7 , together with the estimated average discharge of intercatchment areas, which are small drainage basins confined to foothill areas near the valley floor. Dams have been built in most of the main wadis (table 7). Additional dams may be constructed in the highlands of larger wadis to capture available flood runoff and treated wastewater for potential MAR use (Abdallat and others, 2020). The estimated discharges of catchment areas downstream of existing dams (table 8) are substantial in only two basins. Winter surface runoff of intercatchment areas and of dams' downstream areas currently discharge to the Jordan River and the hypersaline Dead Sea. If suitable areas are available, these flows could be captured for use in MAR to improve water supply.

The runoff model for this study provides an estimate of the surface runoff (fig. 31) and accumulated annual runoff (fig. 32) from the Jordan River valley area. The model, as described above, was compared to streamflow discharge data at 12 gages in the study area. The model does not account for the presence of dams or withdrawals from the channel. In addition, the model does not account for flow losses during runoff down channel. These data may thus be considered an approximate upper limit on the water availability from precipitation in the form of overland flow and runoff (and not base flow from groundwater).

\section{Groundwater}

The shallow groundwater in the Jordan Valley area in Jordan is found in the alluvial deposits, which are composed of clastic sediments originating from the eastern escarpment of the valley. The decreasing gradient from the mountain foothills towards the Jordan River allowed the coarse-grained sediments to be deposited at the foothills of the valley and the fine-grained sediments (clays) to be deposited close to the Jordan River, which resulted in rapidly declining permeability of the sediments towards the river. Therefore, the groundwater velocities in these alluvial sediments decrease rapidly in the westerly direction.

The banks of the Jordan River are built of the Lisan Formation, which in the southern half of the valley contains salty groundwater and is itself partly composed of soluble salts (gypsum and halides). Therefore, as groundwater flows towards the Jordan River, it becomes gradually more salty as it moves towards the river. The alluvial fans generally contain fresh water close to the foothills and salty water downgradient towards the Jordan River (Salameh and Abdallat, 2020a, b).

\section{Suitability for Managed Aquifer Recharge}

The potentials of different parts of the eastern lower Jordan Valley area for MAR were classified and mapped using the results of geologic, hydrologic, and geophysical surveys (Salameh and Abdallat, 2020a, b; fig. 33; table 9). The amounts of rechargeable water in the different potential MAR 


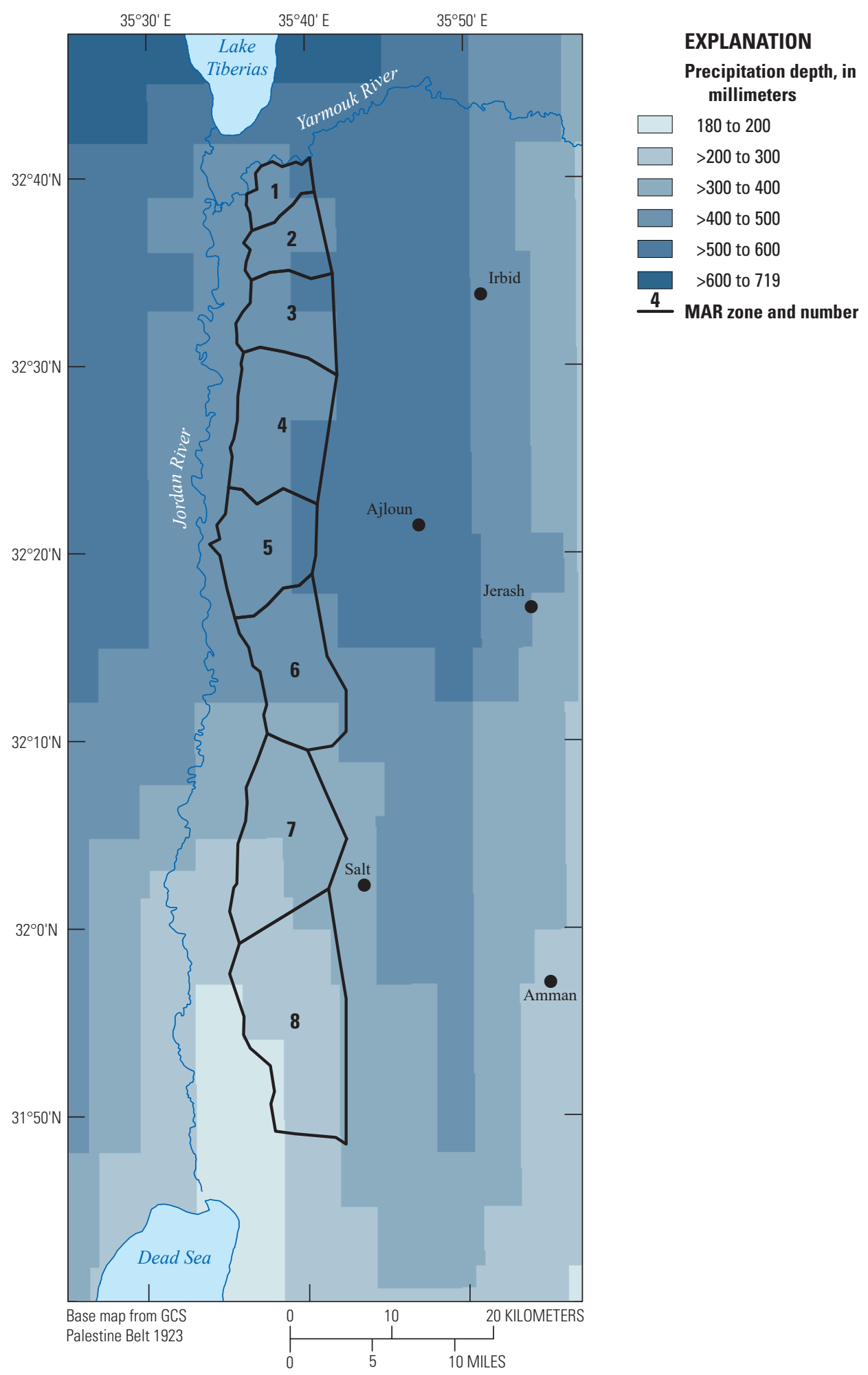

Figure 30. Average annual precipitation depth estimated from remote sensing data in the lower Jordan Valley area, Jordan, 1984-2015 (Kagone and others, 2021). 
Table 7. Average annual predevelopment stream discharge of major streams and intercatchment areas between major streams in the lower Jordan Valley, Jordan (after Salameh and Abdallat, 2020a, b).

$[-$, none $]$

\begin{tabular}{|c|c|c|c|c|c|}
\hline Major streams & Dam & Basin ID & $\begin{array}{l}\text { Flood flow (million } \\
\text { cubic meters } \\
\text { per year) }\end{array}$ & $\begin{array}{c}\text { Base flow (million } \\
\text { cubic meters } \\
\text { per year) }\end{array}$ & $\begin{array}{l}\text { Total (million cubic } \\
\text { meters per year) }\end{array}$ \\
\hline Yarmouk & Wahda, Adasiya & - & 182 & 218 & 400 \\
\hline El-Arab & El-Arab & $\mathrm{AE}$ & 6.48 & 24.90 & 31.38 \\
\hline Ziqlab & Ziqlab & $\mathrm{AF}$ & 2.2 & 8.3 & 10.5 \\
\hline Yabis & - & $\mathrm{AH}$ & 1.63 & 6.2 & 7.83 \\
\hline Rajib & - & - & 1.31 & 3.0 & 4.31 \\
\hline Kufranja & Kufranja & AJ & 1.02 & 5.8 & 6.82 \\
\hline Zarqa & King Talal & - & 46.52 & 48.3 & 94.82 \\
\hline Shueib & Shueib & - & 1.77 & 8.0 & 9.77 \\
\hline Arab and Ziqlab & - & AB21 & 5 & 1 & 6 \\
\hline Ziqlab and Jurm & - & AB22 & 3 & 1.5 & 4.8 \\
\hline Jurm and Yabis & - & $\mathrm{AB} 23$ & 1.5 & 0.0 & 1.5 \\
\hline Yabis and Kufranja & - & $\mathrm{AB} 24$ & 0.1 & 1.3 & 1.4 \\
\hline Kufranja and Rajib & - & $\mathrm{AB}$ & 0.2 & 1.2 & 1.4 \\
\hline Rajib and Zarqa & - & $\mathrm{AB} 10$ & 0.1 & 0.3 & 0.4 \\
\hline Zarqa and Shueib & - & $\mathrm{AB} 25$ & 3.5 & 0.0 & 3.8 \\
\hline Shueib and Kafrain & - & - & 2 & 0.4 & 2.4 \\
\hline Kafrain and Hisban & - & AB26 & 0.0 & 1.3 & 1.3 \\
\hline
\end{tabular}

areas were estimated using values of porosities and storage coefficients, which were obtained from field tests, including pumping tests. Additional consideration was given to the presence of rechargeable aquifers having sufficient porosity, depth to water in the shallow subsurface available to store recharge water, and water quality and quality changes expected from recharge (Abdallat and Salameh, 2019).

As an example, in zone 5 (Suleikhat area) in the Yabis and Kufranja inter-catchment AB24 (table 7), a suitable site

Table 8. Estimated local surface runoff downstream of existing dams in the lower Jordan Valley, Jordan (after Salameh and Abdallat, 2020b).

\begin{tabular}{cc}
\hline Dam & $\begin{array}{c}\text { Surface runoff } \\
\text { (million cubic meters per year) }\end{array}$ \\
\hline Wadi Arab & Negligible \\
Ziqlab & 0.5 \\
King Talal & 0.7 \\
Shueib & Negligible \\
Kafrain & Negligible \\
\hline
\end{tabular}

for MAR was found in an abandoned gravel pit with an area of around $140,000 \mathrm{~m}^{2}$ and a depth of $15 \mathrm{~m}$ (Salameh and Abdallat, 2020b; fig. 34). The site is within a kilometer of the King Abdullah Canal, the north-south conduit for domestic and irrigation water supply for the valley. Field test results at the gravel pit site are reported by Salameh and Abdallat (2020a). The weighted average infiltration rate from field testing was 1.36 millimeters per hour, which was considered relatively high given the accumulated silt in the pit after approximately 40 years of quarry operation. Field porosity measurements averaged 0.16 and ranged between 0.12 and 0.25 . The water quality of flood waters in nearby undisturbed wadis is generally good, with an electrical conductivity measurement of 213 microsiemens per centimeter $(\mu \mathrm{S} / \mathrm{cm})$, which indicates it has lower total dissolved solids (salinity) than the local groundwater. The electrical conductivity of the groundwater in the upgradient area is $1,000-1,200 \mu \mathrm{S} / \mathrm{cm}$, suitable for local use. The groundwater level is $20-30 \mathrm{~m}$ below land surface and the highly permeable alluvial sediments can infiltrate recharged water with easy withdrawal from downgradient wells. 


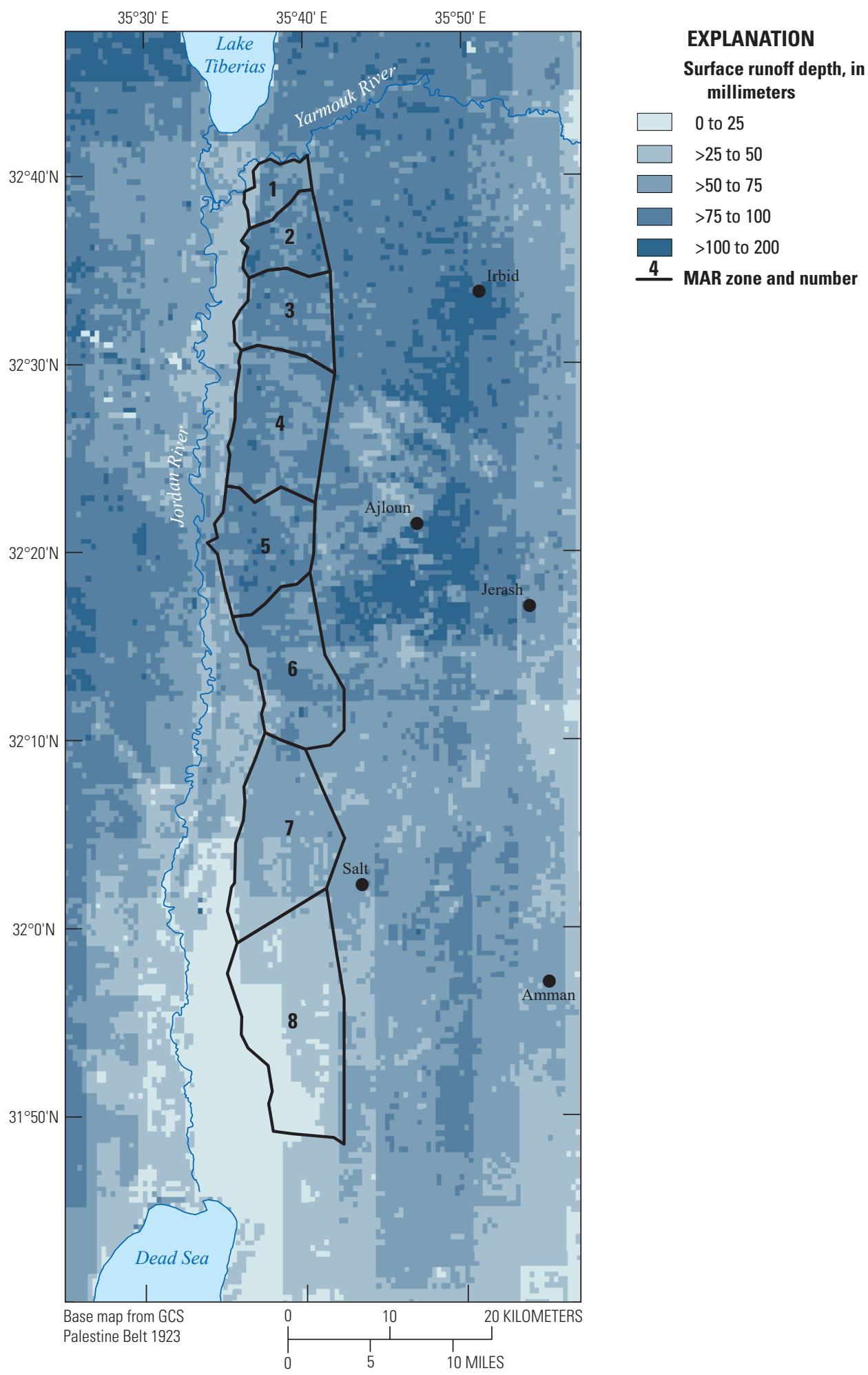

Figure 31. Average annual surface runoff depth simulated in the lower Jordan Valley area, Jordan, 1984-2015. 

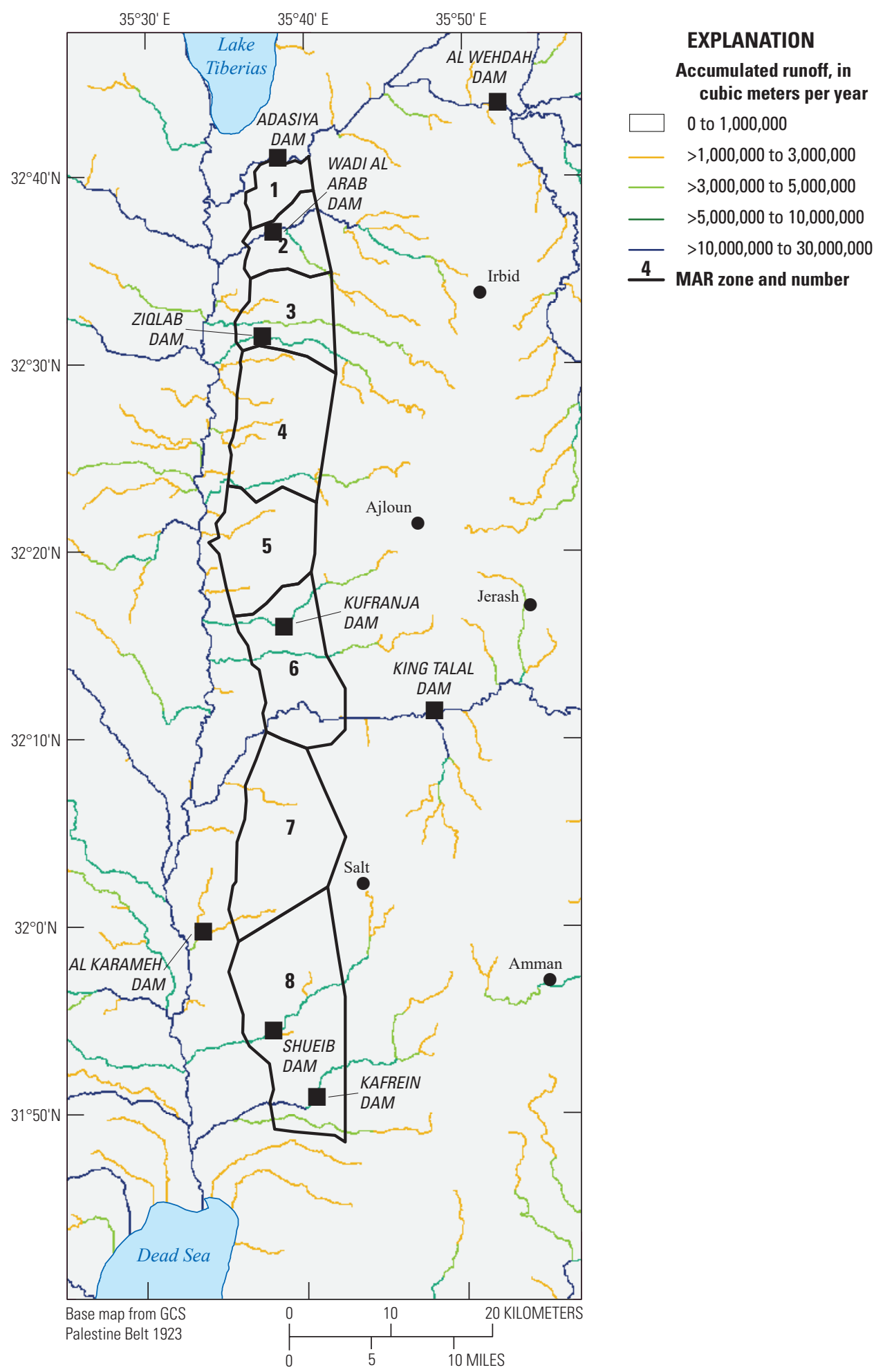

Figure 32. Average annual stream discharge from surface runoff simulated in the lower Jordan Valley area, Jordan, 1984-2015. 

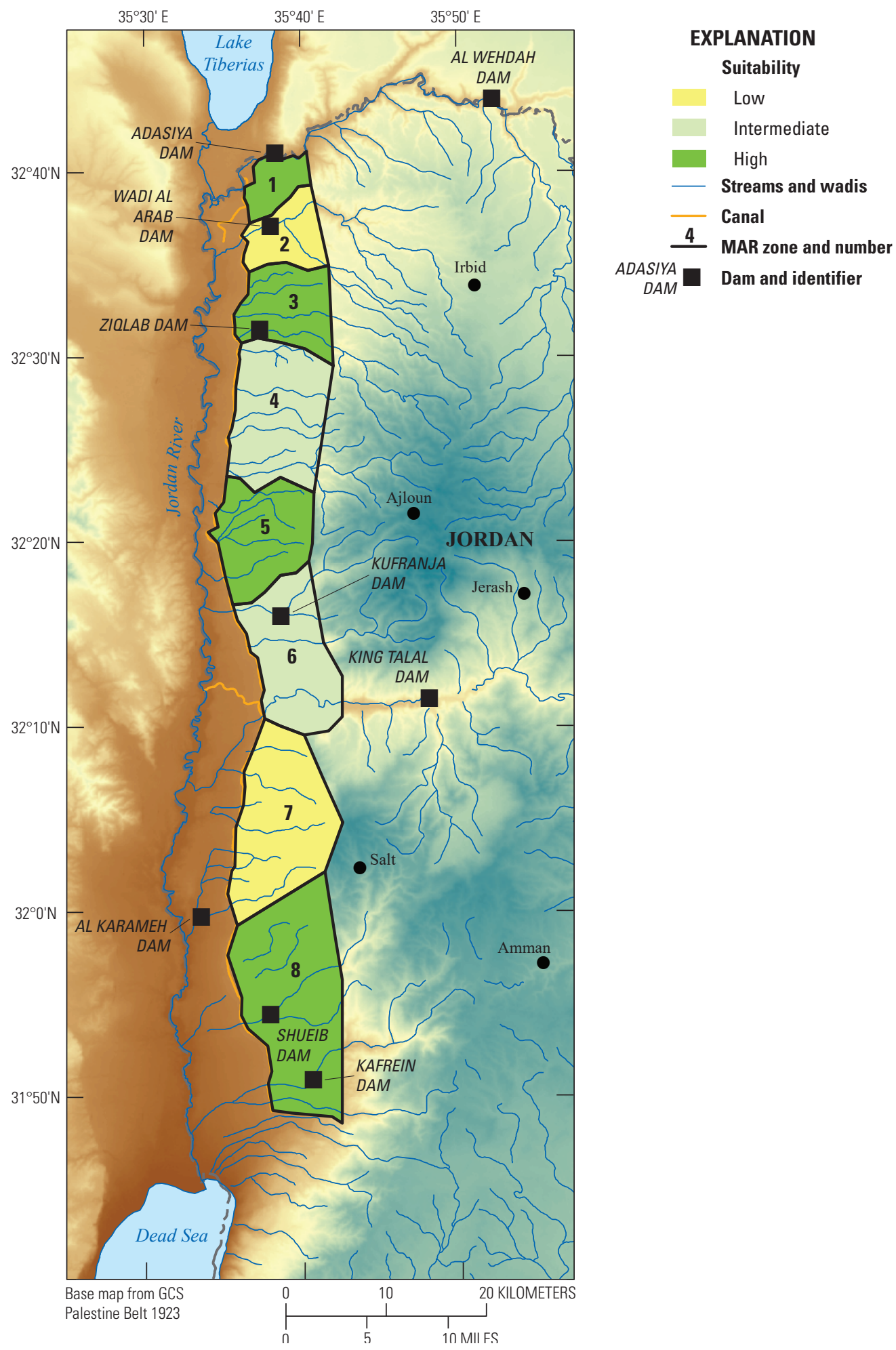

Figure 33. Managed aquifer recharge suitability in the lower Jordan River valley (after Salameh and Abdallat, 2020a, b). 
Table 9. Summary of managed aquifer recharge (MAR) suitability ranking for zones along the foothills of the eastern lower Jordan Valley, Jordan (after Salameh and Abdallat, 2020a, b).

[K, hydraulic conductivity (permeability); WA, water availability; -, not evaluated; JR, Jordan River; gw, groundwater]

\begin{tabular}{|c|c|c|c|c|c|}
\hline $\begin{array}{l}\text { MAR } \\
\text { zone }\end{array}$ & $\begin{array}{l}\text { Area and (or) wadi } \\
\text { names }\end{array}$ & Positive factors & Negative factors & MAR Potential & $\begin{array}{l}\text { Maximum groundwater } \\
\text { storage capacity } \\
\text { (million cubic meters) }\end{array}$ \\
\hline 1 & $\begin{array}{l}\text { Yarmouk/Wadi Al } \\
\text { Arab }\end{array}$ & High porosity and K, WA & $\begin{array}{l}\text { High water table; variable gw } \\
\text { quality, upwelling of saline } \\
\text { waters }\end{array}$ & High & 15 \\
\hline 2 & Wadi Al Arab & WA & Very low K & Low & - \\
\hline 3 & $\begin{array}{l}\text { Wadis Teibeh and } \\
\text { Ziglab }\end{array}$ & $\begin{array}{l}\text { High porosity and } \mathrm{K}, \mathrm{WA}, \\
\text { runoff water quality }\end{array}$ & $\begin{array}{l}\text { Close to JR, upwelling thermal } \\
\text { gw, agrochemical use }\end{array}$ & High & 20 \\
\hline 4 & Abu Saleh to Yabis & High porosity and $\mathrm{K}$ & $\begin{array}{l}\text { Small area of alluvial deposits, } \\
\text { close to JR }\end{array}$ & Intermediate & - \\
\hline 5 & Suleikhat & $\begin{array}{l}\text { High porosity and } \mathrm{K} \text {, low } \\
\text { water table, low gw salinity, } \\
\text { local use/demand }\end{array}$ & Limited WA & High & 10 \\
\hline 6 & $\begin{array}{l}\text { Zarqa River/ } \\
\text { Suleikhat }\end{array}$ & Aquifer conditions, WA & $\begin{array}{l}\text { Agrochemical use, gw use } \\
\text { limited to irrigation }\end{array}$ & Intermediate & 10 \\
\hline 7 & $\begin{array}{l}\text { Zarqa River/ } \\
\text { Karama }\end{array}$ & WA & High gw salinity & Low & - \\
\hline 8 & $\begin{array}{l}\text { Karama to Dead } \\
\text { Sea }\end{array}$ & Large area of suitable land & $\begin{array}{l}\text { High gw salinity, agrochemical } \\
\text { use, impaired gw quality }\end{array}$ & High & 50 \\
\hline
\end{tabular}

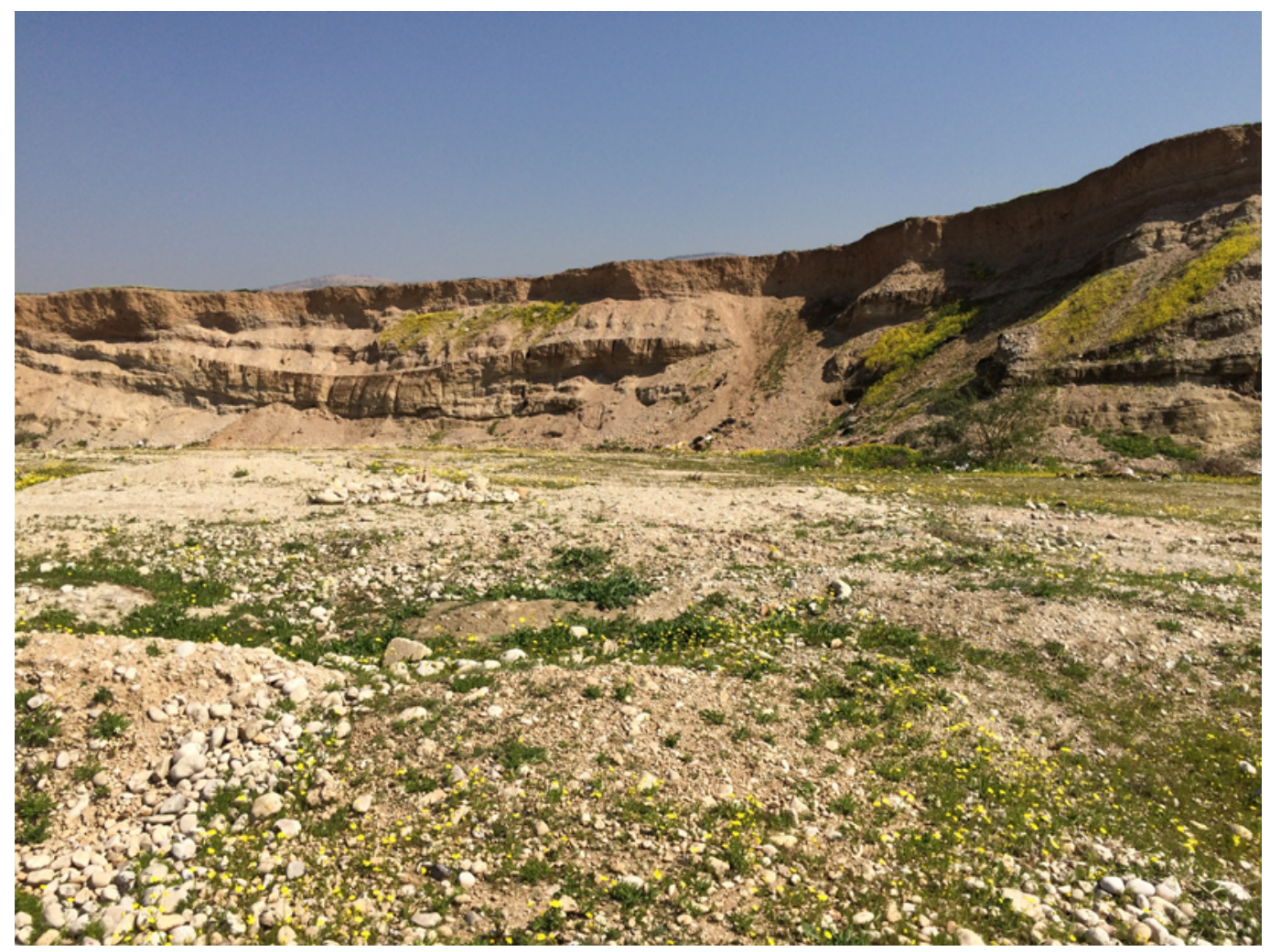

Figure 34. Suleikhat gravel pit identified as a potential MAR site (in Zone 5, fig. 33) in the Yabis and Kufranja (AB24) intercatchment area (table 7) of the lower Jordan River valley, Jordan. Photograph by Daniel J. Goode, U.S. Geological Survey. 


\section{Lebanon Case Study}

\author{
By Nour Alhouda Itani', Ghinwa Harik', Ibrahim \\ Alameddine', Mutasem El-Fadel', and Daniel J. \\ Goode $^{2}$
}

\section{Introduction}

Most economic sectors in Lebanon depend on groundwater, which supplies more than half of irrigation water needs and around 80 percent of distributed potable water (Ministry of Environment, 2010). Although Lebanon has relatively abundant water resources compared to other areas of the Middle East and North Africa region, water quality, especially in groundwater, has deteriorated substantially (Khair and others, 1994; Ministry of Energy and Water and United Nations Development Program, 2014). Seawater intrusion has occurred in areas of over-pumping from coastal aquifers. Shallow groundwater quality has deteriorated owing to the infiltration of incompletely treated wastewaters. The Ministry of Energy and Water and United Nations Development Program (2014) report that aquifers in most of the interior groundwater basins have experienced groundwater-level declines. Surface waters are also stressed owing to the pollution of rivers and reservoirs by incompletely treated wastewaters and agricultural runoff (Ministry of Environment, 2010).

Lebanon has a semiarid Mediterranean climate with dry summers and relatively abundant annual precipitation, primarily in winter months. Nationally, natural groundwater replenishment is estimated to exceed current withdrawals by at least 2,000 million cubic meters per year (MCM/yr). However, many aquifer basins are stressed and withdrawals exceed natural recharge by as much as $150 \mathrm{MCM} / \mathrm{yr}$ (Ministry of Energy and Water and United Nations Development Program, 2014).

Managed aquifer recharge (MAR) can help mitigate water stress when implemented at suitable sites (Dillon and others, 2014). However, the complexity of subsurface systems, the absence of well-established regulations on groundwater use, conflicts with surface water users, and the need for high capital costs often discourage decision makers from adopting this measure (Itani and others, 2021). The Ministry of Energy and Water and United Nations Development Program (2014) estimated that MAR can increase water supply by 100 to 200 $\mathrm{MCM} / \mathrm{yr}$ from natural sources and about $100 \mathrm{MCM} / \mathrm{yr}$ from treated wastewater. In addition to minimizing the recharge deficit in areas of high withdrawals, MAR can help coastal aquifers retard seawater intrusion (Ministry of Energy and Water and United Nations Development Program, 2014) and

\footnotetext{
${ }^{1}$ American University of Beirut, Department of Civil and Environmental Engineering.

${ }^{2}$ U.S. Geological Survey.
}

provide an alternative approach for water storage and subsequent recovery. MAR has been shown to be an attractive substitute to surface water storage in reservoirs where water is prone to pollution and evaporative losses, and steep terrain and local land use may limit the space available for reservoirs. MAR can also reduce social and environmental concerns associated with land expropriation for the building of dams; it can also enhance the social acceptance of indirect wastewater reuse, after that water has passed through aquifers and mixed with natural groundwater (Ringleb and others, 2016).

The use of MAR to augment natural aquifer recharge is expected to become more critical owing to the projected drop both in snow cover extent and duration as a result of future climate change. Shaban (2009) reported that snow cover extent and precipitation decreased 12 and 16 percent, respectively, from 1965 to 2005 . The average time that dense snow covered the Lebanese mountains decreased from 110 days per year to less than 90 days per year over the same time period (Shaban, 2009). As a result of these changes, the average discharge from springs dropped from 104 to $49 \mathrm{MCM} / \mathrm{yr}$ over the same period (Shaban, 2009), while groundwater levels dropped between 5 and $13 \mathrm{~m}$ (Shaban, 2011).

Early MAR initiatives in Lebanon date back to 1968, when the Ministry of Energy and Water attempted to recharge the Cenomanian (International Commission on Stratigraphy, 2021) (late Cretaceous) limestone aquifer in the Beirut area by injecting water from the Beirut River through the Daychounieh canal, which brought the river water to recharge wells (Itani and others, 2021). The aim of the project was to offset the early signs of seawater intrusion into the aquifer and to provide additional recharge to the aquifer for use during the dry season. Systematic recharge started in the spring of 1969 and continued for 2 years. Overall, the project recharged a total of $5 \mathrm{MCM}$ and installed several observation wells close to the recharge wells in order to monitor salinity, hardness, and water levels. The results showed that the recharge operation was able to raise water levels, reduce groundwater hardness, and offset the saltwater wedge (Daud, 1972). Another MAR project took place in the 1970s in Damour, south of Beirut. The project aimed to inject water originating from the Damour River into the nearby coastal aquifer. Unfortunately, the project was terminated early owing to the outbreak of the Lebanese Civil War and all relevant data from the project were lost (Itani and others, 2021).

In 2014, a collaboration between the Lebanese government and the United Nations Development Program prepared a country-scale assessment of groundwater resources in Lebanon (Ministry of Energy and Water and United Nations Development Program, 2014). Twenty-two suitable MAR sites in 12 groundwater basins were identified. The recharge volume was estimated to range between 104 and $208 \mathrm{MCM} /$ yr. The study also identified another 10 sites as suitable for recharge with treated wastewater, with a recharge volume ranging from 103 to $118 \mathrm{MCM} / \mathrm{yr}$. The selection criteria adopted by the study to identify MAR-suitable basins were based on the aquifer's water stress, storage capacity, and depth 
to the water table. The study utilized data on the geology, hydrology (springs, wells, groundwater levels, flow directions, meteorological data, basin water budget), and hydrogeology (aquifer characteristics) of the area. The Ministry of Energy and Water and United Nations Development Program (2014) concluded that the most suitable MAR method would be injection wells (commonly known as Aquifer Storage and Recovery [ASR]) because of the high permeability of karst aquifers and the small footprint of wells compared to spreading basins. The Ministry of Energy and Water and United Nations Development Program study was followed by several feasibility studies (for example, Arab Resources Development, 2003) and most recently by the development of a multicriteria decision analysis framework for ranking sites (Rolf, 2017).

As part of the project for this report, a case study of MAR suitability in the Damour River Basin in Lebanon was conducted by faculty and Ph.D. students at the American University of Beirut, in cooperation with the other authors of this report. Methods and results presented in this report are from the Damour River Basin study area report by Itani and others (2021), with modifications to the map display of results, primarily of runoff-model results.

We extend the approach of Rolf (2017) with a focus on the Damour River Basin (fig. 35; site NA14 of Ministry of Energy and Water and United Nations Development Program, 2014). We evaluate the potential suitability by simulating water availability potential using available remote sensing datasets and mapping suitability within the basin. Ministry of Energy and Water and United Nations Development Program (2014) estimated that the total volume that can be recharged in the Damour River Basin ranges between 9 and $18 \mathrm{MCM} /$ $\mathrm{yr}$, assuming that 5 to 10 percent of the entire river flow can be made available for recharge.

The Damour River begins in the eastern part of the basin, at an elevation of more than $1,900 \mathrm{~m}$ above sea level along the western slopes of the Lebanon Mountains. The river drains two main subbasins and the basin area is about 290 square kilometers $\left(\mathrm{km}^{2}\right)$. The basin is bounded by the Beirut River Basin on the north and by the Awali River Basin on the south and southeast (Massoud, 2012; Khair and others, 2016). The Mount Lebanon water divide limits the basin on the east and the Mediterranean Sea limits it on the west. The basin has several mountain ranges, valleys, and plains, in addition to side streams and small and large tributaries. Deep valleys and canyons are encountered in some areas with relative relief of as much as $700 \mathrm{~m}$ (Kheir and Akar, 1992; Khair and others, 2016).

\section{Geology}

The governing geological formations in the Damour River Basin are mainly Cretaceous and Jurassic in age (fig. 36). The eastern part of the basin is mostly underlain by
Jurassic successions (J4-J7) that consist of massive fractured and karstified carbonates and include the Salima Formation. High infiltration rates dominate these formations, with the fraction of precipitation infiltrating estimated at about 42 percent (Khair and others, 2016). Further downstream at Jisr el Qadi, the Upper Jurassic successions emerge in 50-60-m-high cliff formations (Khair and others, 2016). The central and northern regions of the basin are underlain by Lower Cretaceous rock successions (C1-C3), including the Chouf Formation sandstones (mostly lithified sand), the Abieh Formation (mostly sandy argillaceous limestone, claystone, and shale), the Mdairej Formation (mostly fractured massive limestone), and the Hammana Formation (mostly marl interbedded with fractured limestone beds) (Ministry of Energy and Water and United Nations Development Program, 2014; Khair and others, 2016). The units have very low to moderate infiltration rates (3-13 percent), with the exception of the Mdairej Formation. The southern part of the basin is underlain by the Sannine Formation (dolomite and limestone; C4). Very high infiltration rates dominate this formation, reaching 49 percent in some regions (Ministry of Energy and Water and United Nations Development Program, 2014; Khair and others, 2016). Other formations occur sparsely in the basin, such as Quaternary (Q) landslide deposits, Maameltain Formation (dolomitic and chalky limestone; C5), and the Chekka Formation (marly limestone; C6) east of the river mouth (fig. 6) (United Nations Development Program, 1970; Khair and others, 2016).

\section{Hydrogeology}

The main hydrogeological system of the study area is the upper aquifer (C4-C5) (fig. 36; table 10). Composed of two Cretaceous formations, Sannine Limestone and Maameltain Formation, the C4-C5 is one of two major aquifers in Lebanon. It constitutes a little more than 40 percent of the area of Lebanon and is underlies many basins all over the country. The Sarafand-Khaldi Cretaceous basin constitutes part of this major aquifer and extends beyond the limits of Damour River Basin. It is underlain by a semiconfining unit and a moderately thin lower aquifer. These layers dip towards the west at an angle reaching 55 degrees at its steepest section (Itani and others, 2021). The major aquifer (C4-C5) is unconfined to the east and is semiconfined by an aquitard (C6) to the west, which is also covered by a minor aquifer of Quaternary age. The Quaternary aquifer occupies a small area that is around $7 \mathrm{~km}^{2}$ and is quite shallow. It has a gentle slope and high infiltration rate, even though it is partly urbanized. The aquifer is located above the salt/freshwater interface from seawater intrusion from the Mediterranean Sea. The Cenomanian aquitard C6 is exposed to the surface just to the east of the Quaternary aquifer (fig. 36). It has very low infiltration from precipitation and limited capacity for natural aquifer recharge. Meanwhile, the high elevation eastern parts 


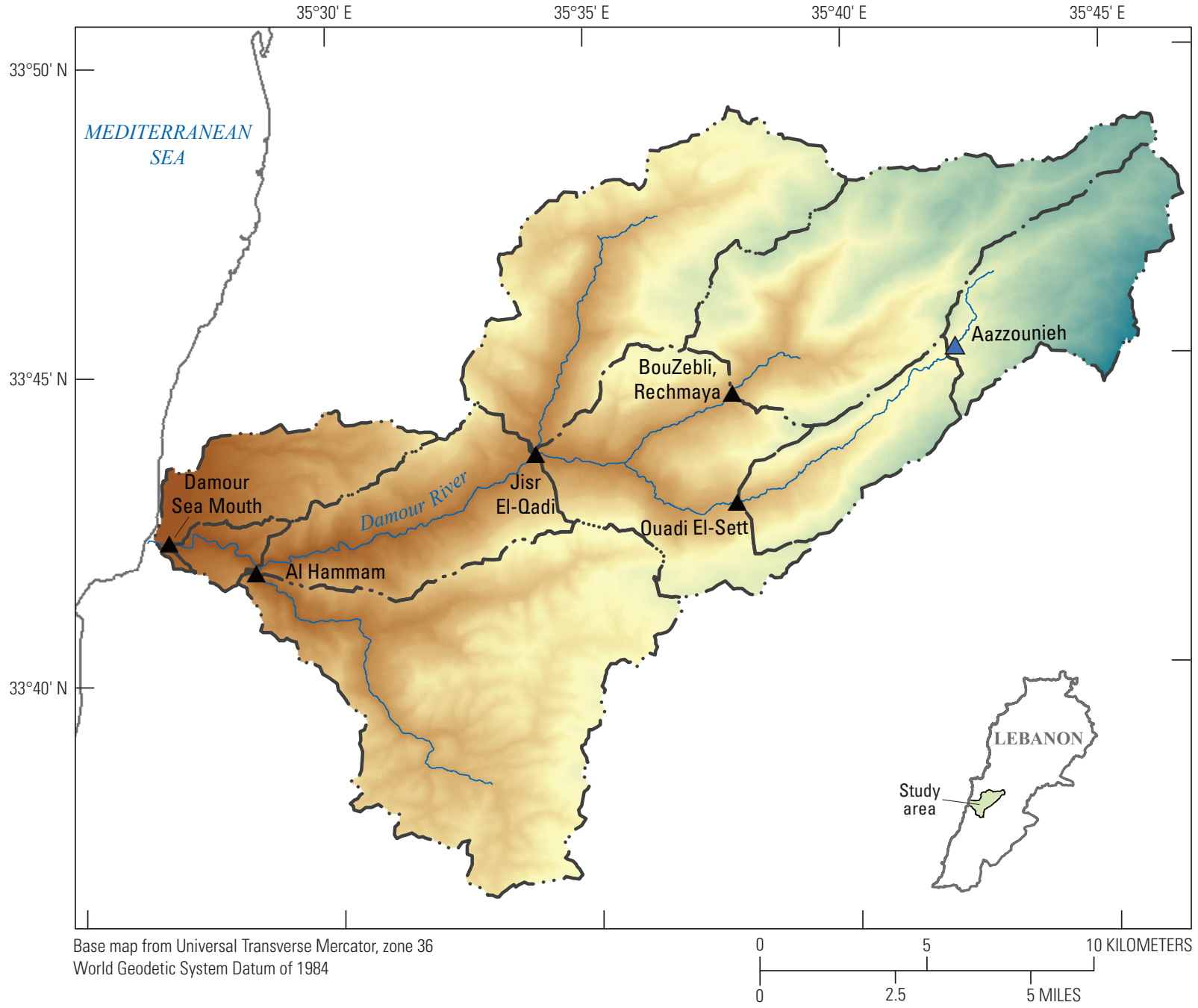

EXPLANATION

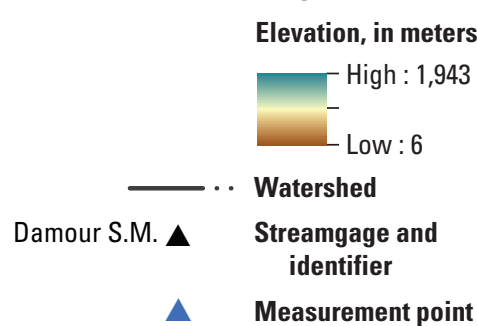

Figure 35. Map of the Damour River Basin in Lebanon, showing topography and locations of streamgages. 


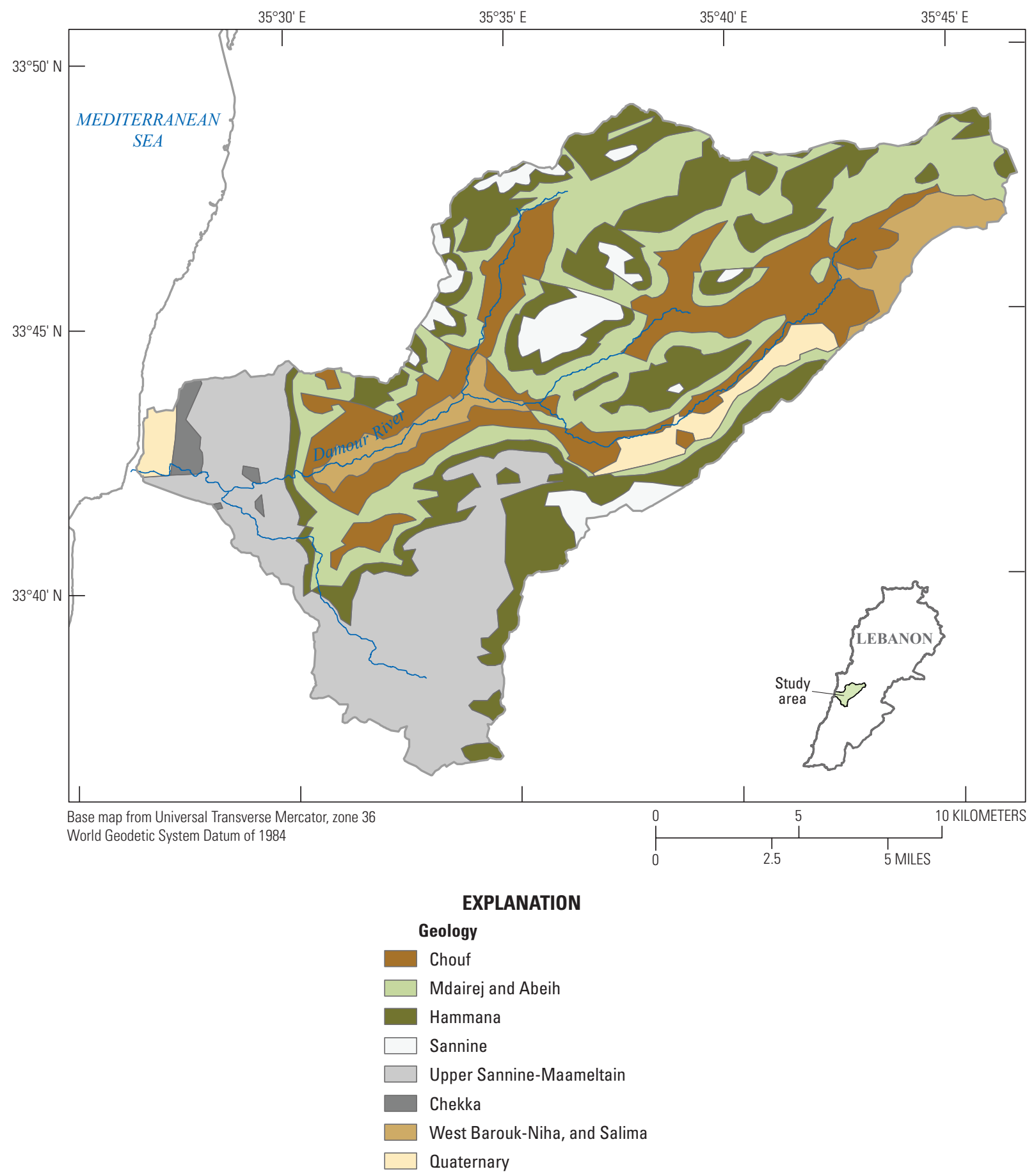

Figure 36. Surface geology of the Damour River Basin, Lebanon (after Itani and others, 2021). 
Table 10. Surface geology of the Damour River Basin, Lebanon (after Itani and others, 2021).

\begin{tabular}{|c|c|c|c|}
\hline Symbol & Formations & Hydrogeology & Description \\
\hline $\mathrm{C} 1$ & Chouf & Aquifer & Ferruginous brown sandstone. \\
\hline $\mathrm{C} 2$ & Mdairej and Abeih & Aquiclude/Semiaquifer & $\begin{array}{l}\text { Jointed and fissured grey micritic } \\
\text { and cliff-forming limestone, } \\
\text { brown green variable unit of } \\
\text { marly limestone interbedded with } \\
\text { thin beds of marl and yellow } \\
\text { brown clayey sandstone. }\end{array}$ \\
\hline $\mathrm{C} 3$ & Hammana & Aquiclude & $\begin{array}{l}\text { Brownish green marl and marly } \\
\text { limestone. }\end{array}$ \\
\hline $\mathrm{C} 4$ & Sannine & Aquifer & $\begin{array}{l}\text { Jointed and fissured dolomite } \\
\text { interbedded with dolomitic } \\
\text { limestone and marly limestone. }\end{array}$ \\
\hline $\mathrm{C} 4-\mathrm{C} 5$ & Upper Sannine-Maameltain & Aquifer & $\begin{array}{l}\text { Jointed and fissured dolomitic } \\
\text { limestone with chalky limestone } \\
\text { and micritic limestone. }\end{array}$ \\
\hline $\mathrm{C} 6$ & Chekka & Aquiclude & $\begin{array}{l}\text { Jointed and fissured chalky to } \\
\text { marly limestone alternating with } \\
\text { marl beds. }\end{array}$ \\
\hline J4-J7 & Salima and other Jurassic rocks & Aquifer & Karstified limestone and marls. \\
\hline Q & Quaternary deposits & Minor aquifer & $\begin{array}{l}\text { Sand, gravel, and clay with } \\
\text { spatial variation. }\end{array}$ \\
\hline
\end{tabular}

of the basin are mostly underlain by Jurassic successions, which are also major groundwater reservoirs in Lebanon (Khadra and Stuyfzand, 2014; Khadra, 2017).

\section{Multi-Criteria Decision Analysis}

Suitability factors were carefully chosen based on those used frequently in MAR siting. The factors were checked to ensure minimality, nonredundancy, and completeness. Digital spatial data for these factors were then collected and processed for uniformity and compatibility, as detailed below. Some data were collected from previous MAR initiatives and were thus digitized and georeferenced in order to use them in our GIS analysis. A few of these factors served as constraining parameters to eliminate implausible sites. This was done using Boolean logic (constraint mapping). Other factors served as input to the suitability mapping that ranked sites based on a suitability score. As such, the Boolean logic model serves only as a preparation step prior to the suitability index calculation. This approach has been shown to produce more accurate maps compared to the use of Boolean logic models alone (Alesheikh and others, 2008). The chosen method for index calculation is the Analytic Hierarchy Process (AHP) (Saaty,
1980), which is an additive weighting model and is "one of the most comprehensive methods of multicriteria decision analysis" (Malczewski and Rinner, 2015). It tolerates having multiple levels within the hierarchy, allowing for first-level factors (three in this case) and second-level factors (nine in total), and it grants a means for directing the decision maker's focus on establishing a proper structure that captures the significant components of the addressed problem along with their interaction (Malczewski and Rinner, 2015). Details on the adopted constraints, thresholds, AHP method, and its corresponding weights and scores used for the MAR site selection process are described by Itani and others (2021).

The suitability was evaluated as an equally weighted sum of three first-level factors, water availability, aquifer rechargeability, and socioeconomic benefits. A quantitative score for MAR suitability was evaluated using a multicriteria geospatial analysis (MCDA; Itani and others, 2021, after Rolf, 2017). The MAR suitability score $(M)$ was defined to range from 0 (unsuitable) to 100 (highly suitable) and was computed as the equally weighted sum of scores, also on a scale of $0-100$, for three first-level factors: aquifer rechargeability $(A)$, water availability $(W)$, and socioeconomic benefit $(E)$ (fig. 37). Thus, $M=(A+W+E) / 3=0.333 A+0.333 W+0.333 E$. The suitability for MAR was computed using GIS at a spatial resolution of $50 \mathrm{~m}$, the resolution of the available DEM 


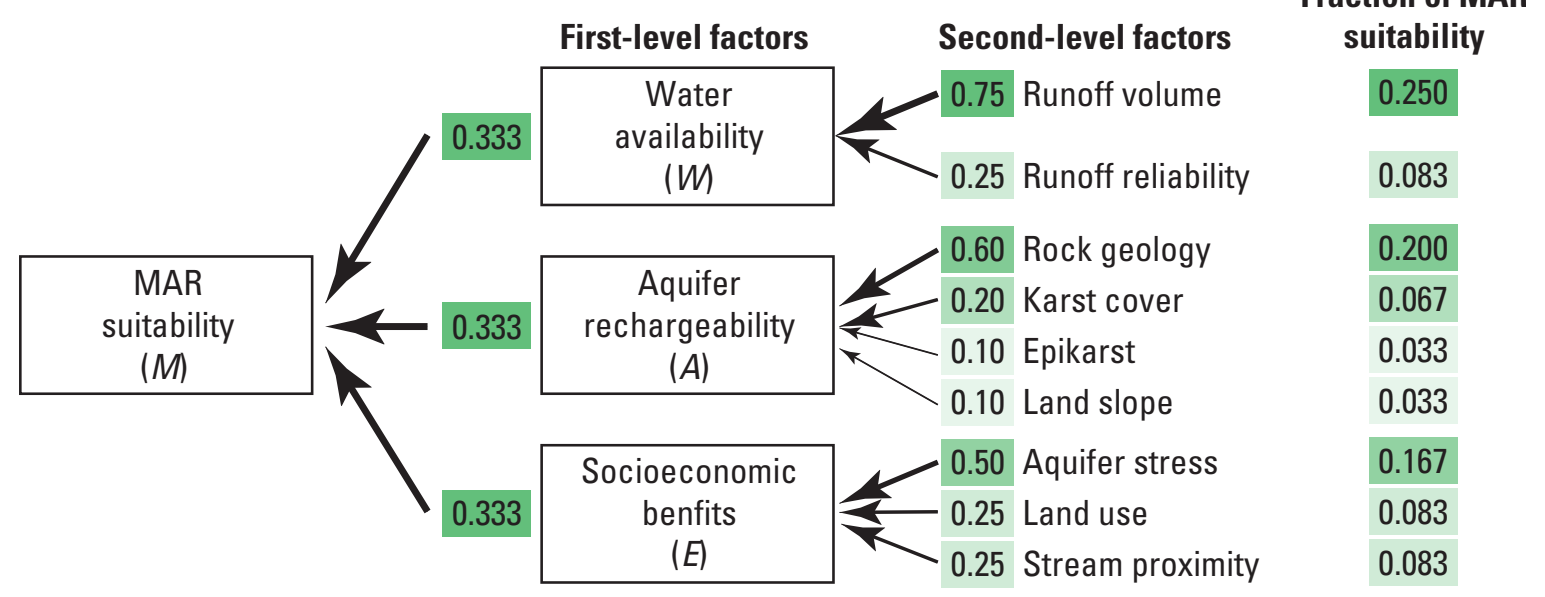

Figure 37. Schematic of Multi-Criteria Decision Analysis (MCDA) showing specified weights (highlighted in green) of first- and second-level factors to compute the managed aquifer recharge (MAR) suitability score $(M)$, and the computed overall fraction of second-level factors in $M$.

(fig. 37). A Python code (Itani and others, 2021) was developed in the GIS to compute the three first-level factor scores and the MAR suitability score.

\section{Aquifer Rechargeability}

Much of the surface geology of Lebanon is karstic, and it has been recognized that the characterization of recharge processes is dominated by the properties of karst formation near the land surface (Daher and others, 2011). Using the Aquifer Rechargeability Assessment in Karst (ARAK) method of Daher (2011) and Daher and others (2011) we select geology, epikarst, karst cover, and slope as the four factors that characterize the degree to which recharge water can be delivered to aquifers through surface spreading or impoundments.

The geology factor score $(R)$ corresponds to the geologic formations (rock indicator). As can be seen from table 11 , areas with exposed and extremely fractured rocks of the C4-C5 aquifer (fig. 36) were given the highest score, whereas regions underlain by the $\mathrm{C} 2, \mathrm{C} 3$, or $\mathrm{C} 6$ were completely excluded.

Epikarst is a surficial zone in karst formations where weathering has caused fracturing and dissolution of the rock. The fractures and channels in the rock can act as a temporary near-surface reservoir for infiltration from MAR to underlying aquifers. On the other hand, the presence of lower permeability surface features interrupts this slow, consistent recharge (Daher, 2011; Daher and others, 2011). Thus, aquifer rechargeability of areas in Lebanon depends in large part on the presence of epikarst. The epikarst presence factor $(K)$ was scored in three categories, E1, E2, and E3 (Momejian and others, 2019; Itani and others, 2021). The spatial distribution of the three categories of epikarst in the basin are shown in figure 38; the scores assigned to each of the categories are shown in table
11. The scores were calculated as per the linear score function (Malczewski and Rinner, 2015).

The Karst cover factor $(C)$ reflects the extent of karstification of the underlying aquifers (karst indicator). Karst in Lebanon is quite abundant and has previously been classified into four categories based on its exposure: high, moderate, restricted, and covered (Ministry of Energy and Water and United Nations Development Program, 2014). Three of these types are encountered in Damour River Basin: moderate, restricted, and covered (fig. 39). Higher scores were given to areas with lower karstification and were calculated as per the linear score function (Malczewski and Rinner, 2015).

Land-surface slope is an additional factor in terms of the availability of areas that can be used for impounding water to recharge underlying strata. The slope score $(F)$ reflects the infiltration capacity indicator of the basin based on the slope at the surface (Daher, 2011; Daher and others, 2011). The variability of slopes in the study area is high, as there are several mountain ranges and steep slopes along the eastern sections of the basin, along with deep valleys that delineate the river. The gentlest slopes are encountered along the narrow Damour coastal plain to the west (fig. 40). The generated percent slope raster layer was subdivided into the categories defined by the ARAK method (table 5) (Daher, 2011; Daher and others, 2011). A maximum threshold of 50 percent was assigned to surface slopes and cells with steeper slopes were therefore excluded.

The aquifer rechargeability first-level factor score $A$ was computed as a weighted combination of scores for four second-level factors: the rock geology (formation), $R$; the presence of epikarst, $K$; the karst cover, $C$; and the land surface slope, $F$. The aquifer rechargeability score was computed as $A=0.6 R+0.2 K+0.1 C+0.1 F$, using weights determined from AHP pairwise comparison (Itani and others, 2021). More than half of the rechargeability score is determined by the 
Table 11. Second-level factors, classifications, and scores for aquifer rechargeability (after Itani and others, 2021).

\begin{tabular}{|c|c|c|}
\hline Second-level factor & Classifications & Score \\
\hline \multirow{4}{*}{ Geology $(R)$} & Cretaceous $\mathrm{C} 2, \mathrm{C} 3$, and $\mathrm{C} 6$ & Exclude \\
\hline & Quaternary and Cretaceous C1 & 25 \\
\hline & Jurassic J4-7 and lower Cenomanian C4 & 75 \\
\hline & $\begin{array}{l}\text { Exposed and extremely fractured } \\
\text { Cenomanian C4-C5 }\end{array}$ & 100 \\
\hline \multirow[t]{3}{*}{ Epikarst $(K)$} & $\begin{array}{l}\text { E1: Fractures, developed faults, } \\
\text { current/paleo channels/rivers, flood } \\
\text { plains + buffer ( } 500 \text { meters) around } \\
\text { faults + buffer } 500 \text { meters around rivers }\end{array}$ & 0 \\
\hline & E2: Karst outcropping formations & 50 \\
\hline & E3: Absent karstic morphology & 100 \\
\hline \multirow{3}{*}{ Karst cover $(C)$} & High exposure & 0 \\
\hline & Moderate exposure & 50 \\
\hline & Covered or restricted exposure & 100 \\
\hline \multirow{5}{*}{ Slope $(F)$} & Percent rise greater than 50 percent & Exclude \\
\hline & 30 to 49 percent & 25 \\
\hline & 15 to 29 percent & 50 \\
\hline & 5 to 14 percent & 75 \\
\hline & Less than 5 percent & 100 \\
\hline
\end{tabular}

classification of the surface geology, with lower weights used for the epikarst, cover, and slope factors.

Fifty-two percent of the basin area has no artificial recharge potential, particularly for the areas with the Cretaceous $\mathrm{C} 2, \mathrm{C} 3$, and $\mathrm{C} 6$ formations, which are unsuitable for water storage and recovery (fig. 41). The highest potential for MAR is within the Cenomanian C4-C5 geologic formation. Within this region, the contrast between the higher and lower rechargeability scores primarily reflects the difference in recharge suitability based on the epikarst types and slope variations (fig. 41). There is also moderate to low potential for recharge in the small shallow coastal Quaternary aquifer (to the west) and in the other geologic formations along the east flank of the basin. Of the 48 percent of the basin that has some potential for artificial recharge, around 19 percent shows low suitability $(37<A<40)$, around 24 percent shows average suitability $(40<A<60)$, around 50 percent shows good suitability $(60<A<80)$, and only around 6 percent shows very good suitability $(80<A<100)$.

\section{Water Availability}

Lebanon is characterized by a Mediterranean climate, with a moderately warm and dry summer and moderately cold, windy, and wet winter. Normally 80 to 90 percent of the annual precipitation in the basin occurs between November and March (Khair and others, 2016). Scattered rainfall events start in October and end in May. The precipitation rates in the Damour River Basin increase with altitude, from about 900 $\mathrm{mm} / \mathrm{yr}$ around the river mouth area to more than $1,500 \mathrm{~mm} /$ $\mathrm{yr}$ along the ridges on the western basin boundary (Ministry of Energy and Water and United Nations Development Program, 2014; Khair and others, 2016). Future climatic predictions based on the Weather Research and Forecasting dynamical downscaling model forced by HiRAM (High Resolution Atmospheric Mode) have predicted that between 2029 and 2050 precipitation across the country is expected to decrease by as much as 30 percent relative to the reference year of 2008. The model also predicts that the mean summer temperature will increase by $1.5^{\circ} \mathrm{C}$ across the country over the same time period (El-Samra and others, 2017, 2018), which may increase evapotranspiration.

The runoff potential for the Damour River Basin (fig. 42) was downscaled from the regional model described in the Regional Water Availability section of this report. The calibration of the regional model included comparisons between simulated flow statistics from the model and from the monitoring locations in the Damour River Basin (fig. 35; table 12).

For water availability, the average streamflow raster (owing to surface runoff) generated by the VegET model (fig. 43) was used to generate the water availability score, $W$. Note that this streamflow is only part of the total river discharge, which is augmented with the groundwater baseflow. This ensures that an appropriate minimal flow in the river is 


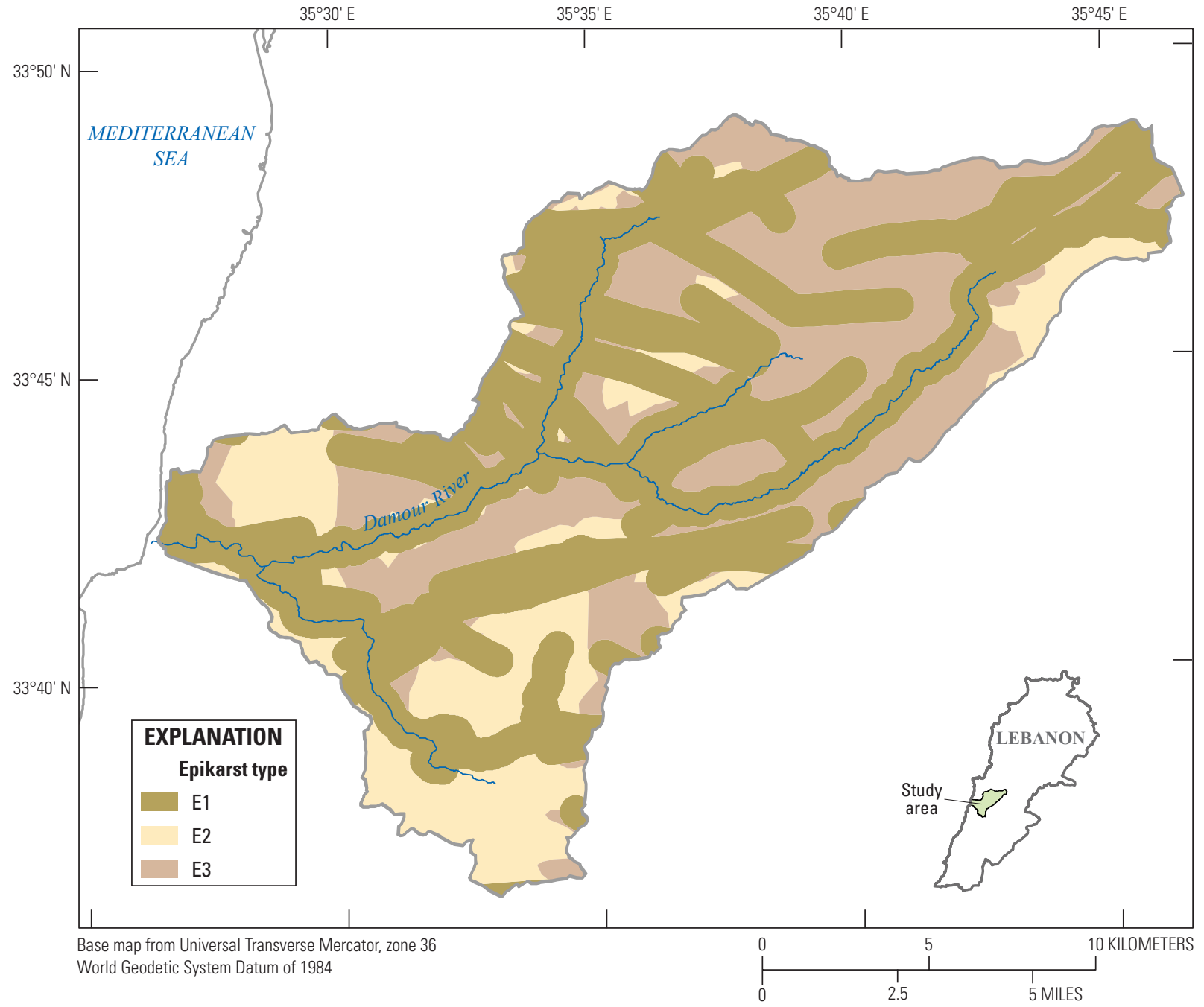

Figure 38. Epikarst classification ( $K$ ) of the Damour River Basin, Lebanon (after Itani and others, 2021). 


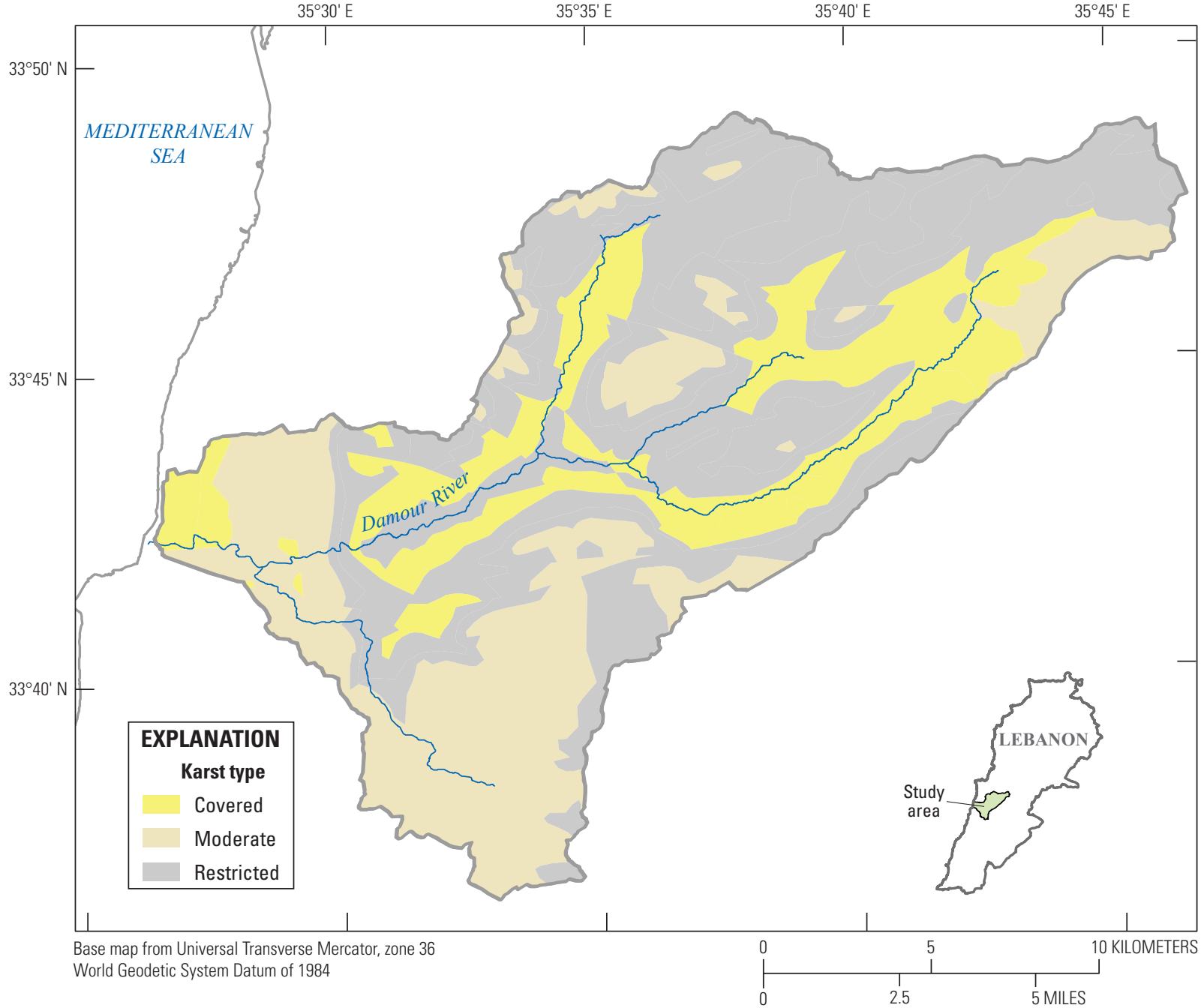

Figure 39. Karst cover classification (C) of the Damour River Basin, Lebanon (after Itani and others, 2021). 


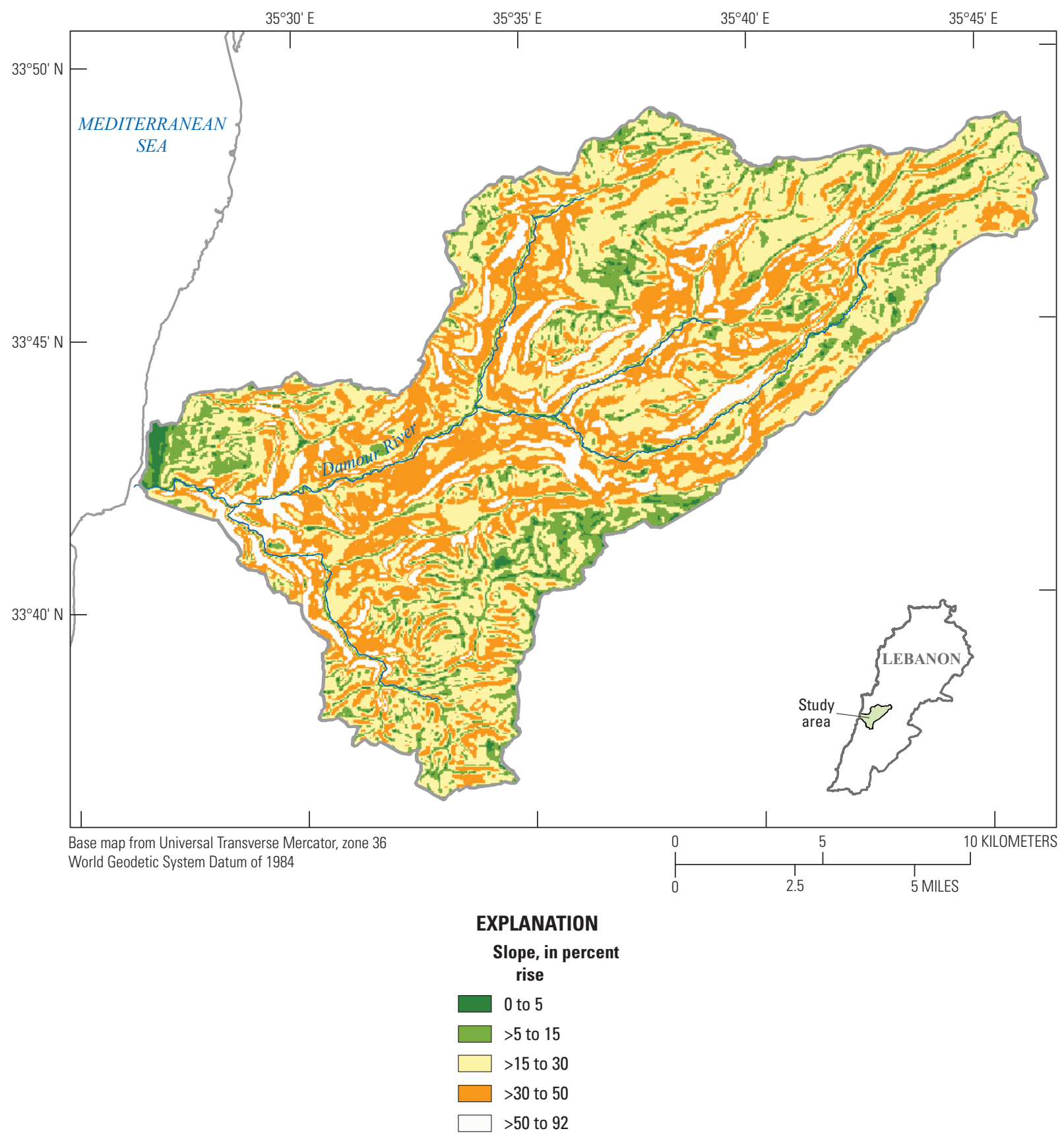

Figure 40. Land surface slope classification ( $F$ ) of the Damour River Basin, Lebanon (after Itani and others, 2021). 


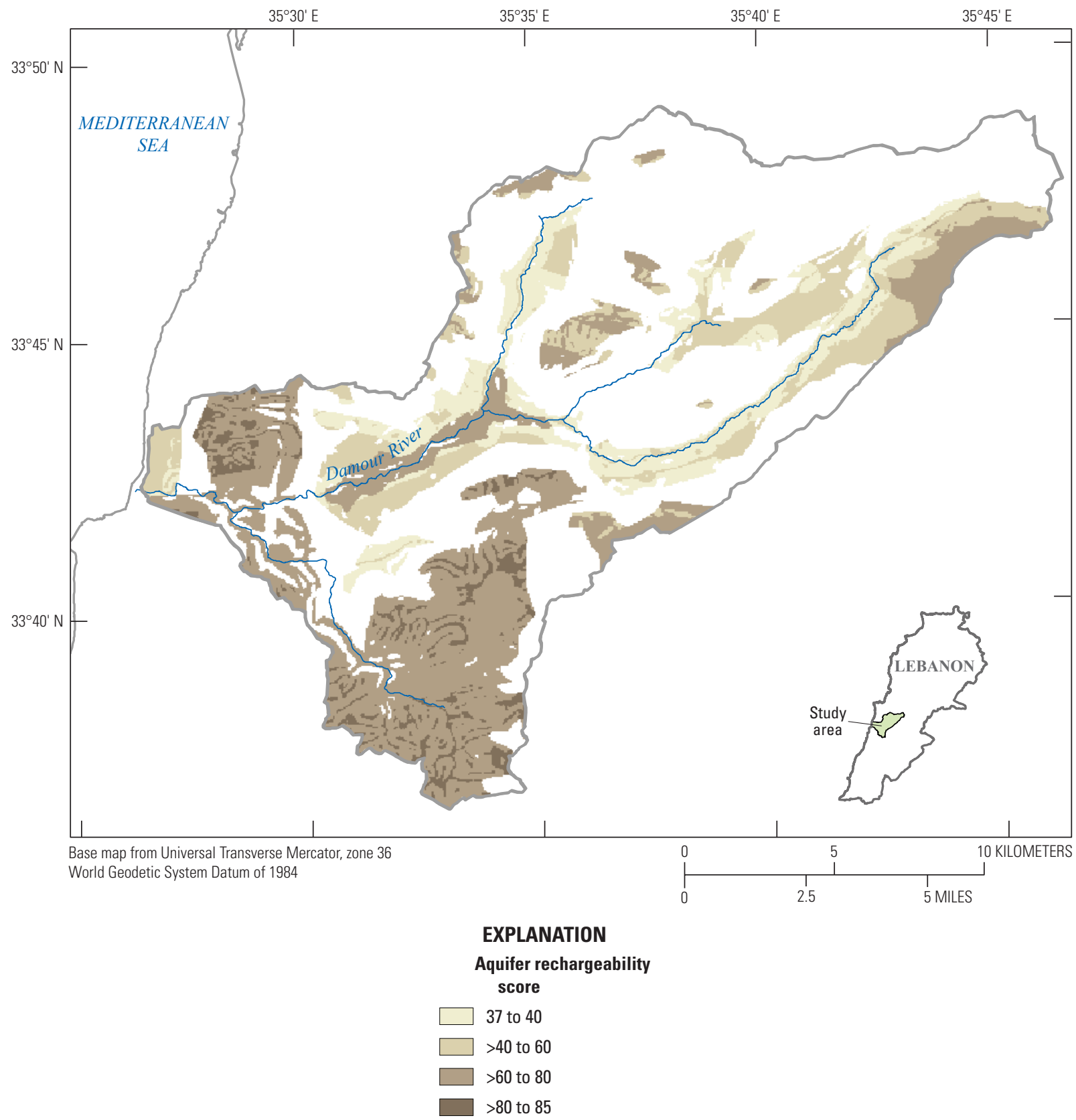

Figure 41. Aquifer rechargeability score (A) of the Damour River Basin, Lebanon (after Itani and others, 2021). 


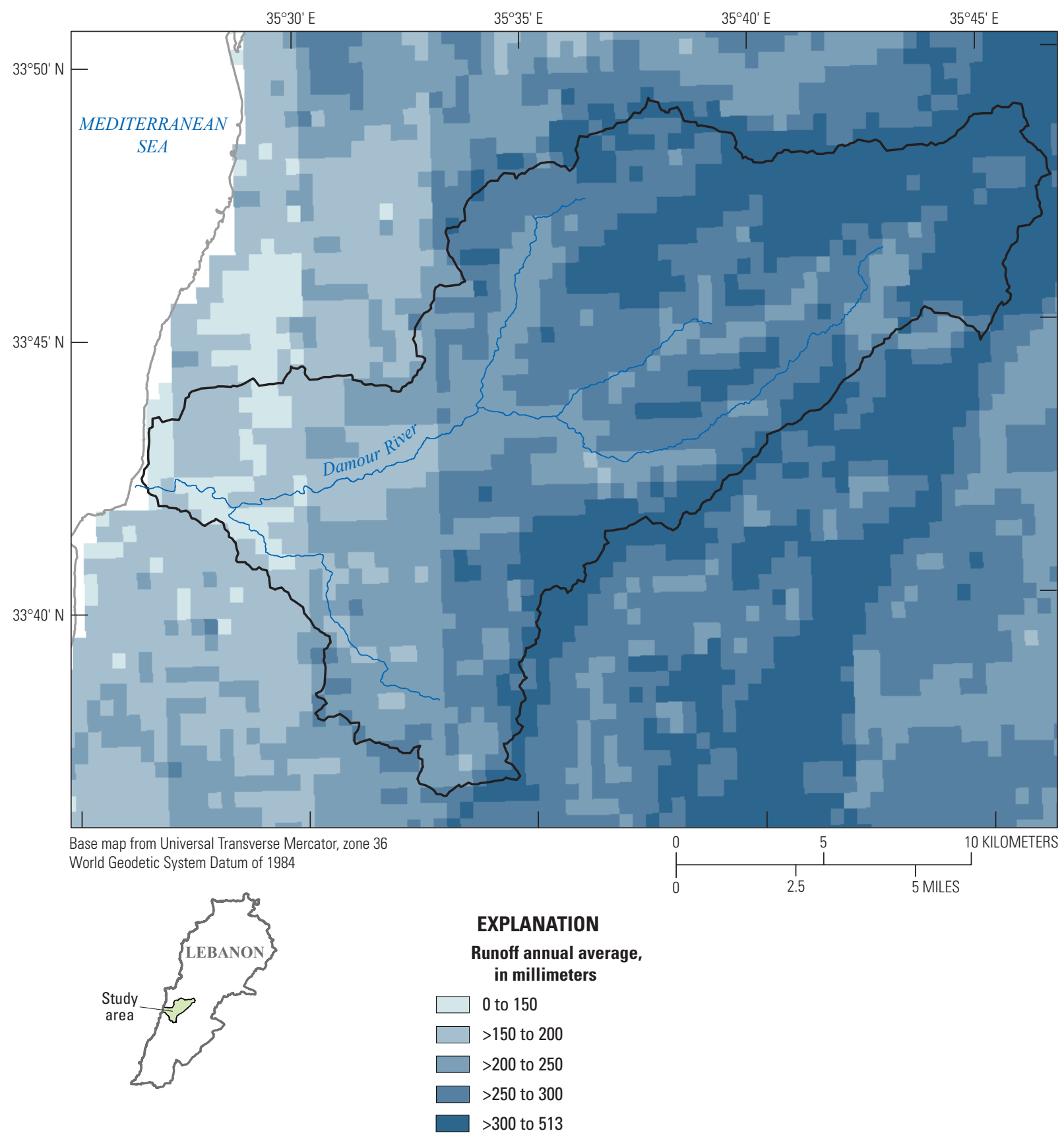

Figure 42. Average annual surface runoff simulated in the Damour River Basin, Lebanon, 1984-2015. 

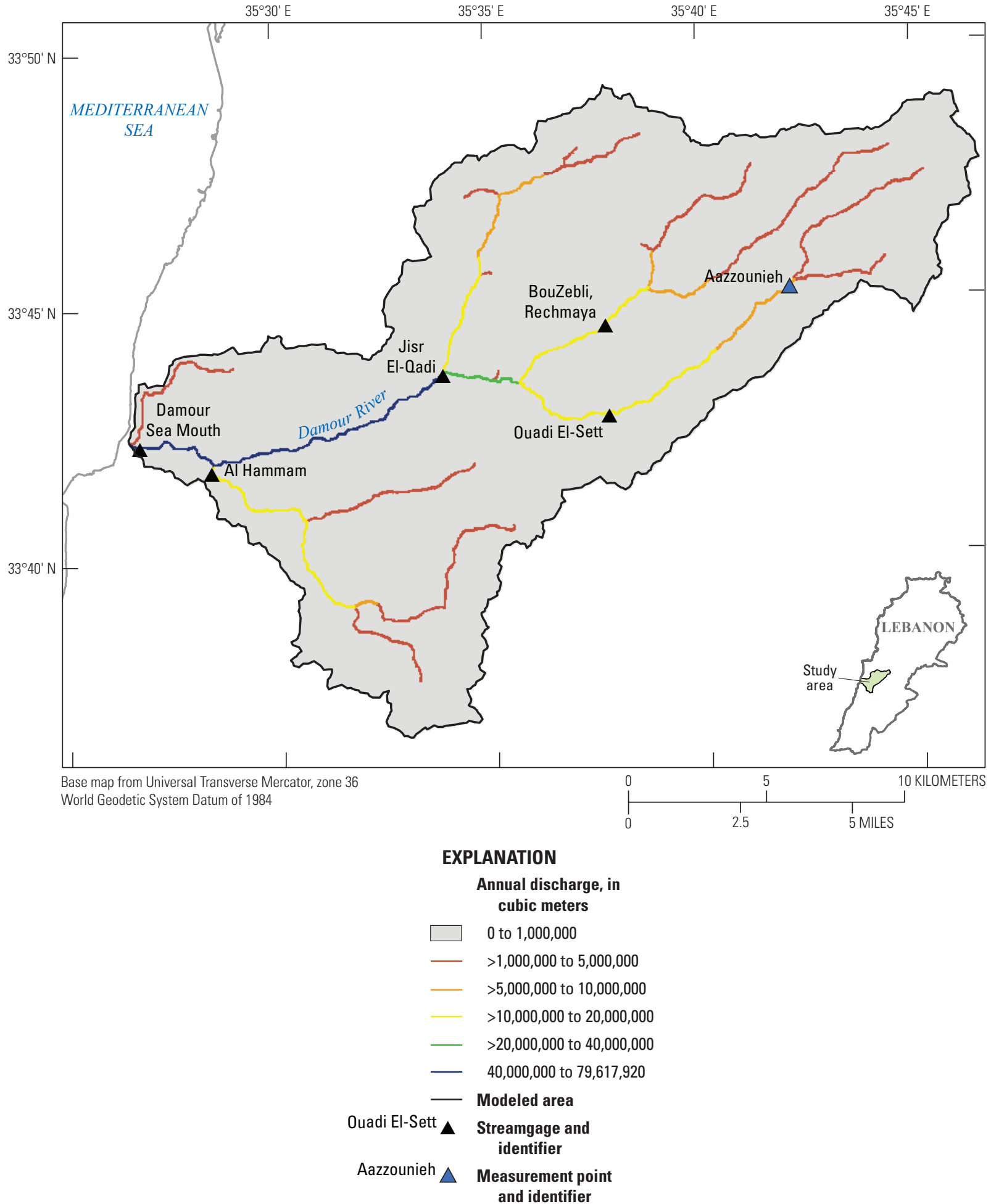

Figure 43. Average annual accumulated surface runoff in streams simulated in the Damour River Basin, Lebanon, 1984-2015. 


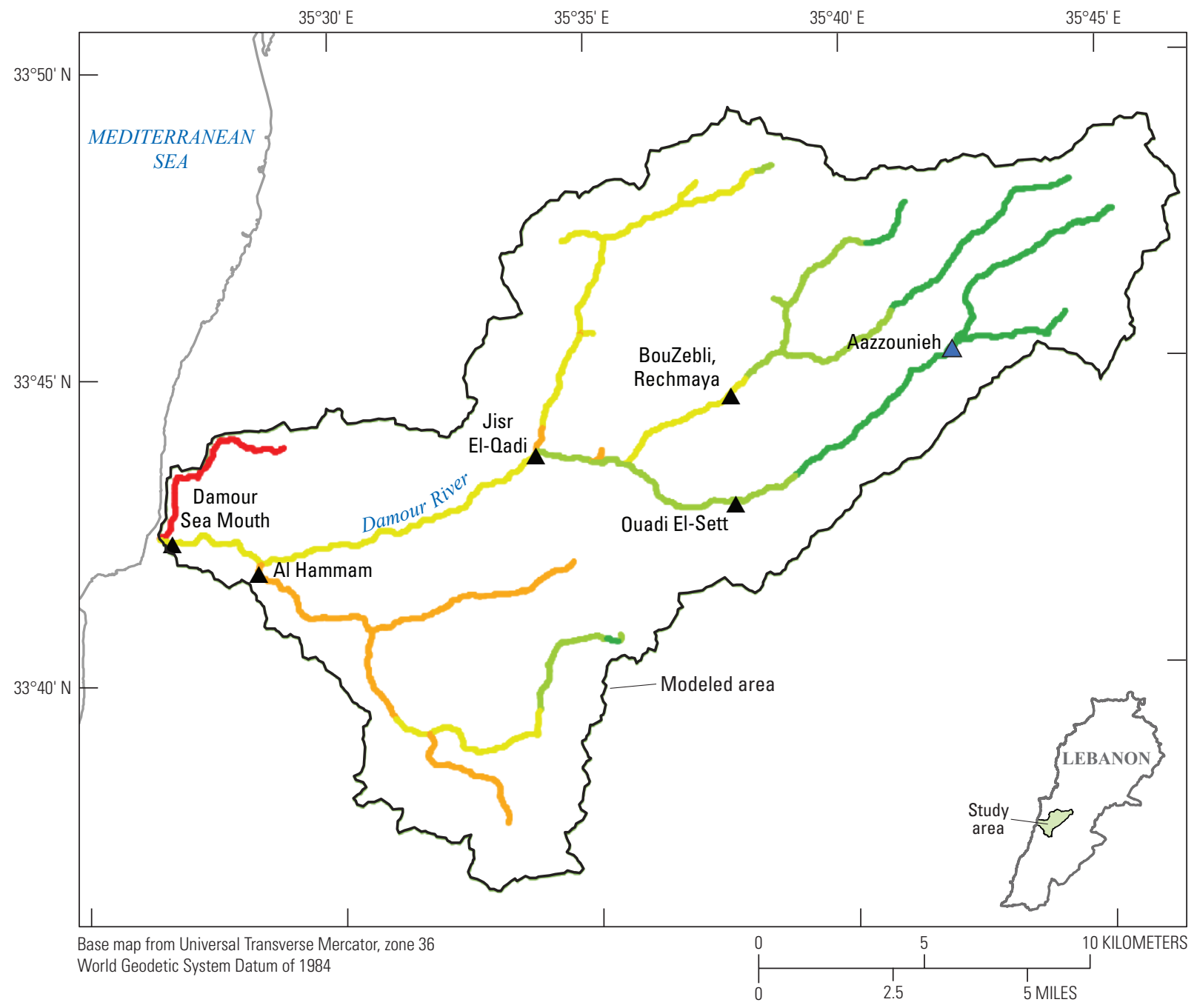

EXPLANATION

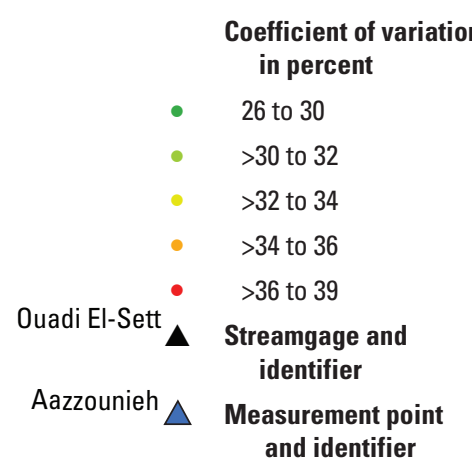

Figure 44. Coefficient of variation (CV) of annual accumulated runoff in streams simulated in the Damour River Basin, Lebanon, 1984-2015 (after Itani and others, 2021). Data shown only for locations with simulated average annual runoff of 1 million cubic meters or more. 
maintained. It also ensures that recharge only occurs during the rainy winter season, where there is maximal flow in the river.

Input values for both runoff volume and reliability second-level factors were determined from the regional runoff model. It is assumed that the available water for recharge at each cell within the basin was equal to the accumulated flow in the nearest cell with accumulated runoff above a specified threshold of 1 million cubic meters per year (MCM/yr), that is in a stream channel. GIS computation of distances from each location to stream channels allowed for the assignment of the volume of streamflow (average annual over 32 years) from the river cells to all other cells within the basin based on that distance. In addition to determining streamflow, the reliability of the available runoff volume owing to the natural variability of precipitation was characterized by the coefficient of variation (CV) of the simulated annual runoff for the period 1984 to 2015 (fig. 44; see Water Availability section of this report). A more reliable site for recharge is a site where there is less variability in the volume available for use as recharge from year

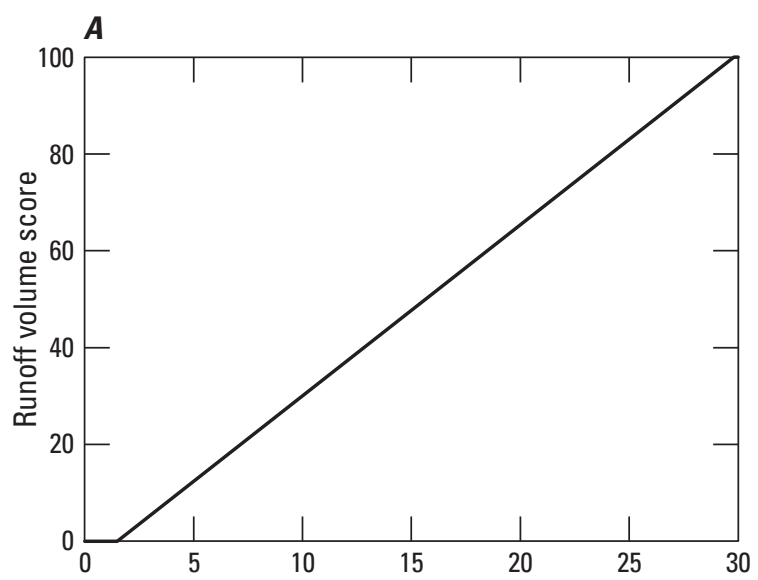

Average annual runoff volume, in million cubic meters

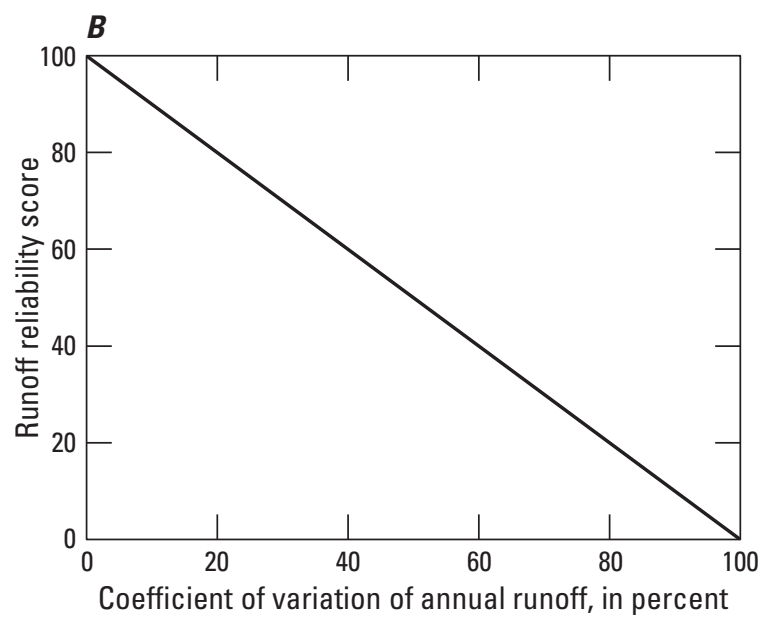

Figure 45. Linear score functions for water availability second-level factors $A$, volume $(\eta)$, and $B$, reliability $(R)$.
Table 12. Streamgages and flow measurement points in the Damour River Basin.

\begin{tabular}{ccc}
\hline Name & Type & Hydrologic feature \\
\hline Ouadi El-Sett & Gage & Stream. \\
BouZebli, & Gage & Stream. \\
Rechmaya & Gage & Stream. \\
Jisr El-Qadi & Gage & Stream. \\
Al Hammam & Gage & Stream. \\
Damour Sea Mouth & Measurement point & Stream. \\
Aazzounieh & &
\end{tabular}

to year, measured by a lower CV. Sites with a high CV may be deemed less reliable for recharge.

The water availability first-level factor score $(W)$ was computed as a weighted combination of scores for two second-level factors: the annual volume of accumulated runoff in the closest stream $(V)$ and the reliability of that volume based on CV $(R)$. The runoff volume score $(V)$ is specified as an increasing linear function of average annual runoff volume in the nearest stream over a specified range from 1.5 $\mathrm{MCM} / \mathrm{yr}(V=0)$ to the maximum $29.8 \mathrm{MCM} / \mathrm{yr}(V=100)$ (fig. $45 A$ ). The runoff reliability score $(R)$ was specified as a decreasing linear function of the $\mathrm{CV}$ of annual runoff volume in the nearest stream over a specified range from $\mathrm{CV}=0$ percent $(R=100)$ to $\mathrm{CV}=100$ percent or more $(R=0)$ (fig. $45 B)$.

The weight for $R$ determined by AHP pairwise comparison (Itani and others, 2021) was one-third of that for $V$, so the water availability score was computed as $W=(3 \mathrm{~V}+R) / 4=$ $0.75 V+0.25 R$. The weights of the runoff volume score $(V)$ and the reliability score $(R)$ for the overall MAR suitability score $(M)$ are thus 0.25 and 0.08333 , respectively. Water availability for MAR is best in the lower parts of the basin, where streams collect runoff from larger areas, hence the runoff volume is higher. The small variation in reliability within the small basin was not an important factor in comparing different parts of the basin.

The water availability score (fig. 46) reflects the high potential for recharge downstream towards the river mouth, where accumulated flows are higher than in upstream regions. Around 80 percent of the basin area shows low to very low relative potential for MAR $(W<40)$. Only 20 percent of the basin has a $W$ score higher than 40 . This region of relatively higher water availability starts at Jisr El-Qadi, where the three northern headwater tributaries of the Damour River merge, resulting in good water availability $(60<A<80)$. The area further downstream and to the west of Jisr El-Qadi shows even higher score owing to the merging of the northern and southern tributaries of the river into one and where there is very good water availability $(80<W<100)$. It should be noted that $W$ variability in the basin was dominated by the accumulated runoff depth $(V)$ and minimally affected by the reliability $(R)$ 


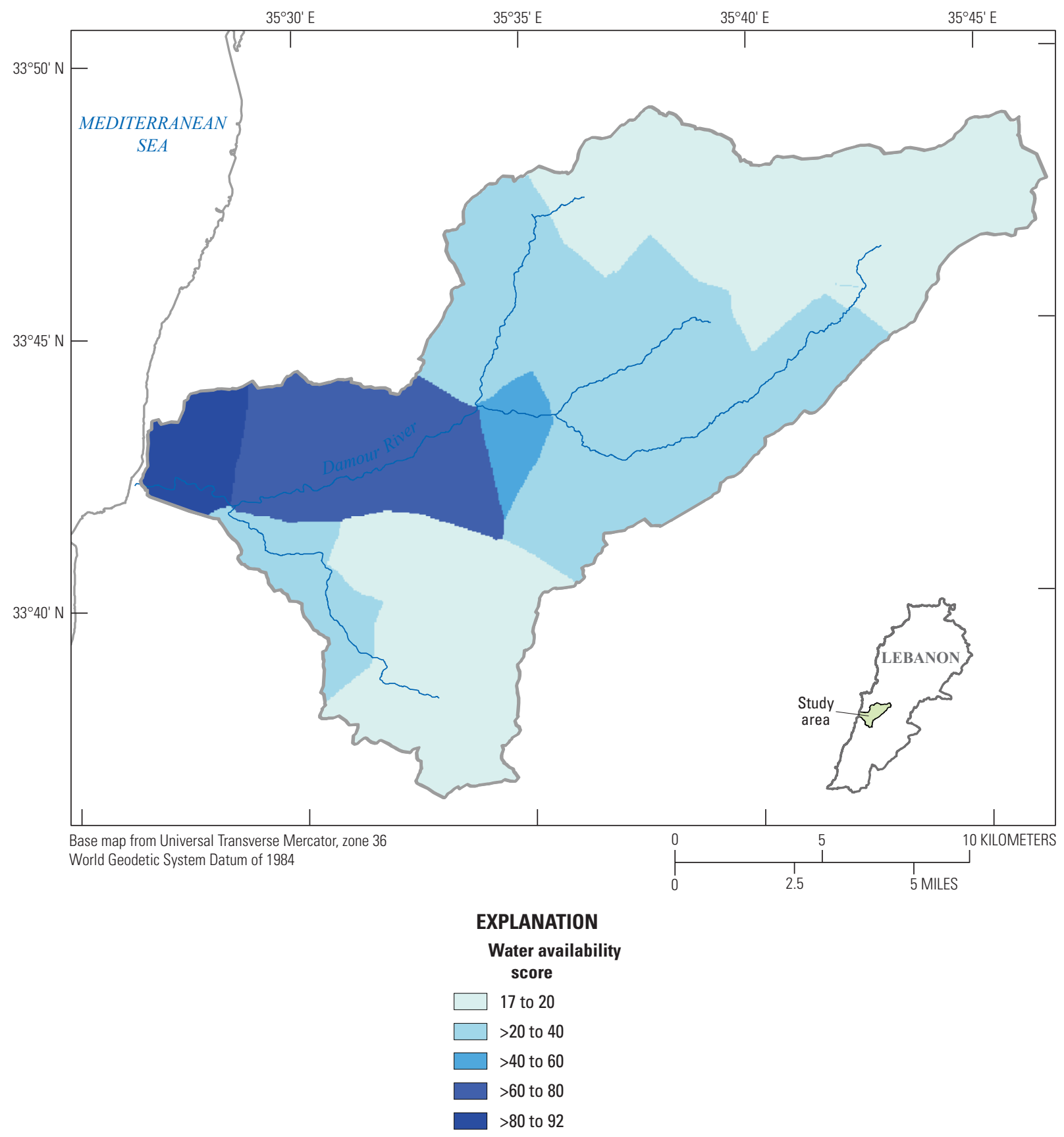

Figure 46. Water availability score for Damour River Basin, Lebanon (after Itani and others, 2021). 
in the accumulated runoff because the $\mathrm{CV}$ varied over a very narrow range between 28 and 35 .

\section{Socioeconomic Benefits}

A third factor, socioeconomic benefits $(E)$, was used to reflect the relative value of MAR at different locations in the Damour River Basin. That value may be related to aquifer rehabilitation, for levels or quality, or to costs or benefits of use of the recharged groundwater close to MAR infrastructure. The socioeconomic benefits $(E)$ score was determined as the weighted sum of three second-level factors

$$
E=0.5 S+0.25 L+0.25 P
$$

where

$E(0-100) \quad$ is the socioeconomic benefits score calculated and $S, L$, and $P$ are the scores of the second-level factors: stress in the aquifer $(S)$, land use/land cover $(L)$, and proximity to river $(P)$, respectively. The weights were determined by AHP pairwise comparison (Itani and others, 2021).

Aquifer stress $(S)$ refers to the anthropogenic stress that the aquifer is facing. Based on a recent national assessment of groundwater (Ministry of Energy and Water and United Nations Development Program, 2014), almost all coastal aquifers in Lebanon are stressed, either as a result of depletion or seawater intrusion. Noncoastal aquifers are generally under low stress, with the exception of those in the Litani River Basin, in the north-south valley between the Lebanon and Anti-Lebanon Mountains. In the Damour River Basin, the only stressed aquifer is the C4-C5 aquifer (Itani and others, 2021; fig. 47). We assigned the C4-C5 aquifer a socioeconomic benefits score $S$ of 100 , whereas all other aquifers were assigned a score of 25 .

Land use/land cover $(L)$ also contributes to the economic attractiveness of the MAR chosen site, where land cost is a major contributor to the overhead cost of the recharge project. Five types of uses are dominant in the Damour River Basin. Wooded areas, agricultural lands, native vegetation, and sparse vegetation types are widely spread and are interspersed with urban areas (fig. 48). We excluded urban areas and water surfaces as not suitable for water storage. We assigned suitability scores between 0 and 100 (table 13) for other dominant land use/land covers in the basin (fig. 48).

The socioeconomic benefit score (fig. 49) indicated around 12 percent of the Damour River Basin was unsuitable
Table 13. Land-use factor suitability scoring.

\begin{tabular}{cc}
\hline Land use & Score \\
\hline Urban & Exclude \\
Agricultural land & 25 \\
Forest & 50 \\
Native vegetation & 75 \\
Sparse vegetation & 100 \\
\hline
\end{tabular}

for MAR, 38 percent of it had low suitability $(21<E<40), 31$ percent had average suitability $(40<E<60), 13$ percent had good suitability $(60<E<80)$, and only 6 percent had very good suitability $(80<E<100)$. The regions of good to very good suitability were collocated in the areas where the aquifer is under stress, which is expected because this indicator is the major contributor to $E$. The regions of high stress are predominantly confined to the regions where the seawater intrusion affected the Cenomanian C4-C5 geologic formation (fig. 47). The socioeconomic benefit score also reflects the effect of land use and land cover on MAR suitability, where urban zones and water surfaces were excluded.

\section{Suitability for Managed Aquifer Recharge}

Finally, the combined MAR suitability score (fig. 50) was generated by executing a weighted sum of the three factors (fig. 37). More than half of the basin is unsuitable for MAR (57 percent). Around 14 percent shows low MAR suitability $(26<M<40)$, around 21 percent shows average suitability $(40<M<60)$, around 7 percent shows good suitability $(60<M<80)$, and only 1 percent shows very good suitability $(80<M<100)$.

The most suitable recharge sites occur across the coastal plain of Damour, within the C4-C5 Cenomanian aquifer. Suitability is high owing to water availability downstream of the confluence of the two branches of the Damour River. Another region of good MAR potential is a bit further upstream in the J4-J7 aquifer. The regions of average potential for MAR tended to be found along the shallow coastal Quaternary aquifer and along the southern part of the basin, in addition to smaller regions further upstream. The least favorable recharge sites were at the headwaters of the basin in the Quaternary, C1, and $\mathrm{C} 4$ aquifers. Aquifers in these areas are not under stress and water availability is also lower. 


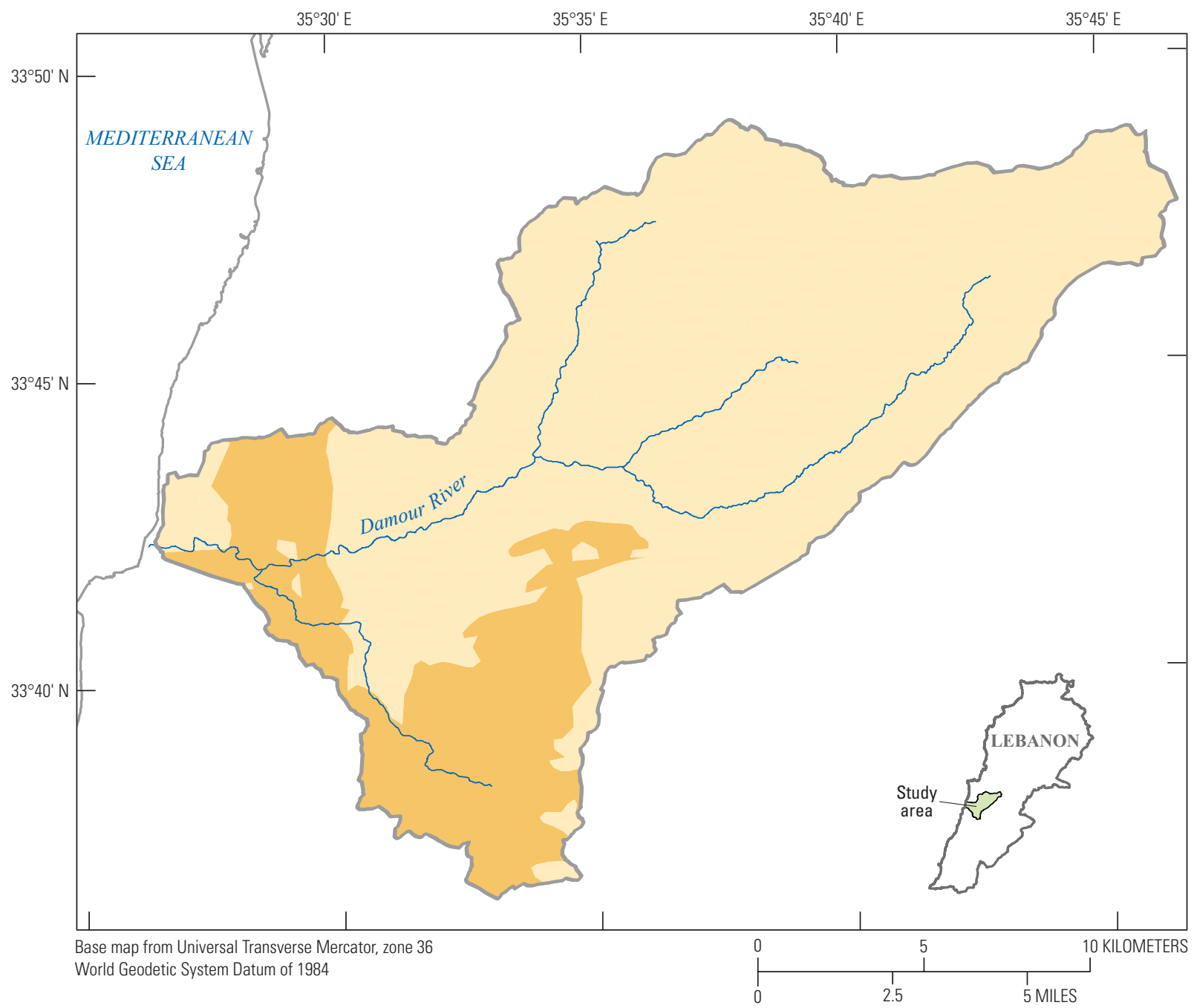

EXPLANATION

Aquifer stress classification

Stressed

Unstressed

Figure 47. Aquifer stress in the Damour River Basin (after Itani and others, 2021). 


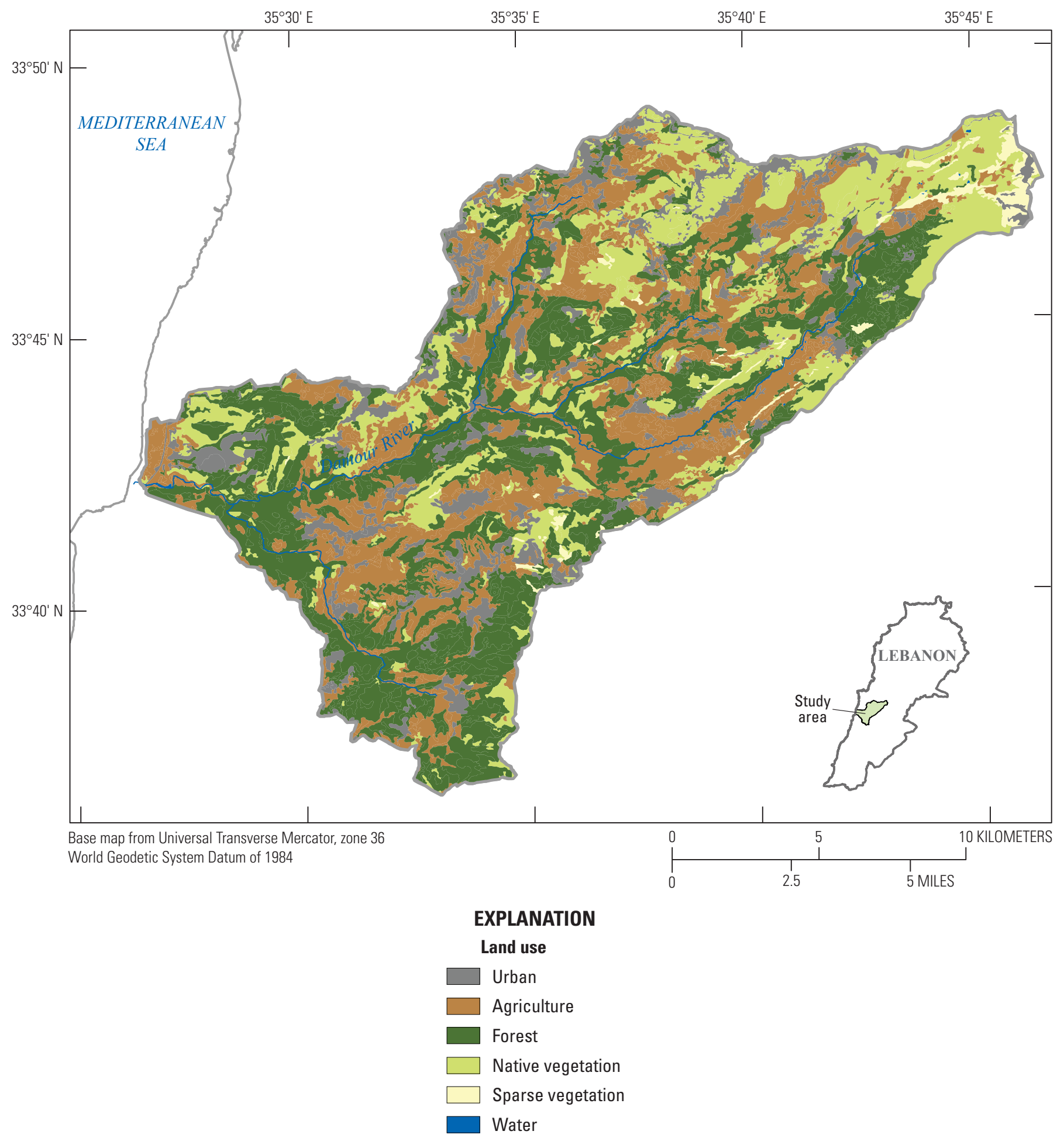

Figure 48. Land use of the Damour River Basin (after Itani and others, 2021). 


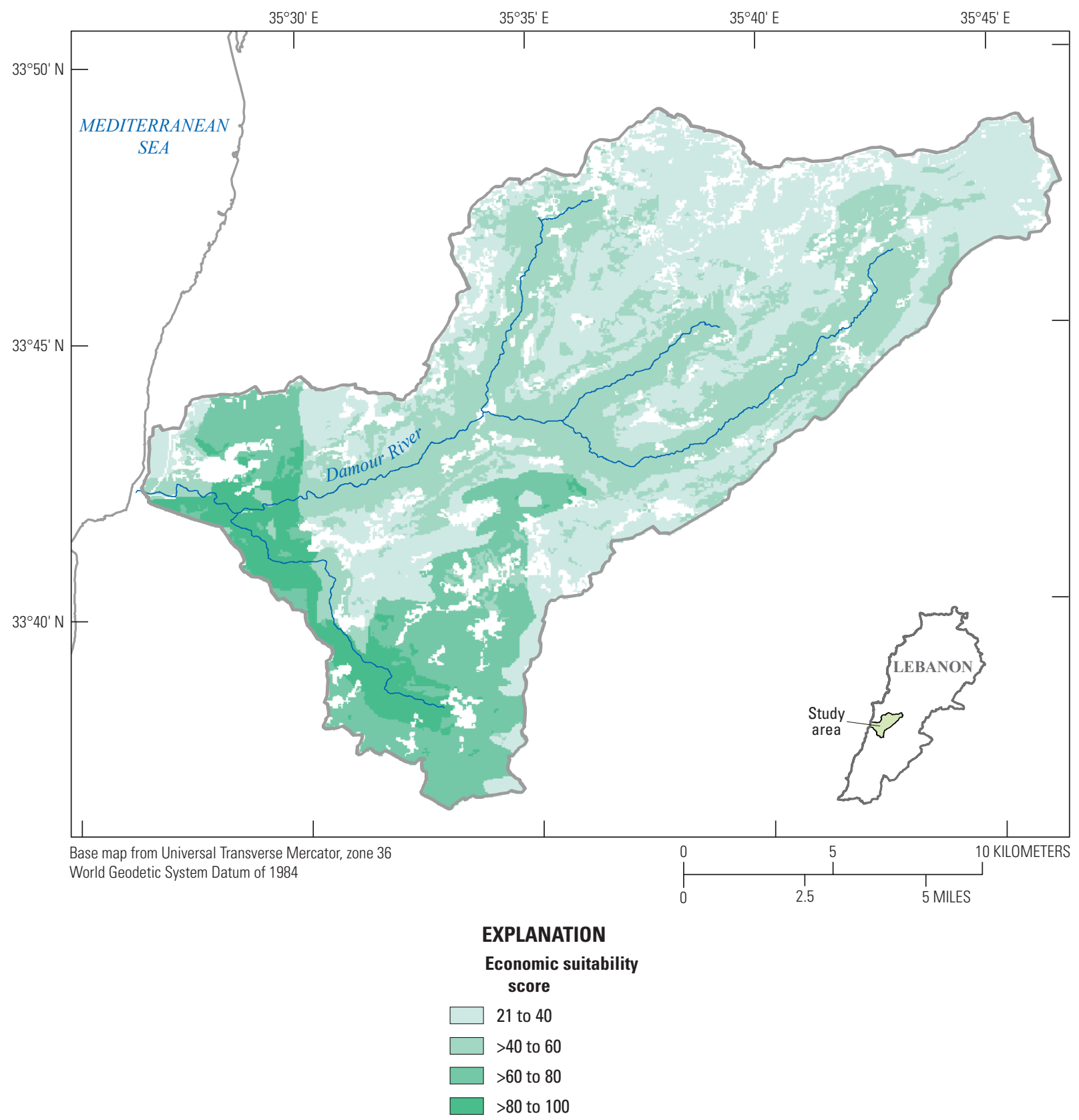

Figure 49. Socioeconomic benefit score $(E)$ of the Damour River Basin, Lebanon (after Itani and others, 2021). 


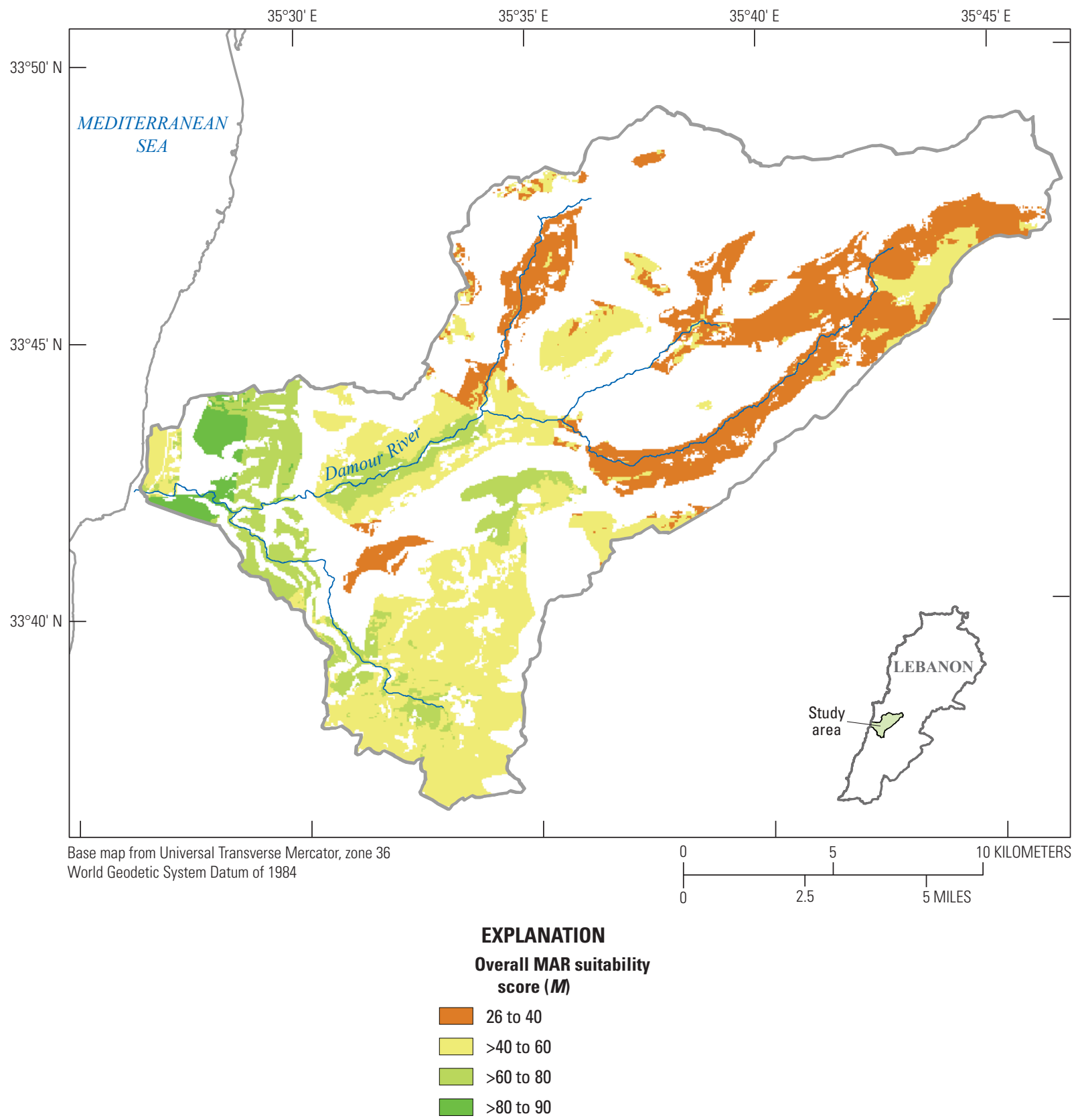

Figure 50. Managed aquifer suitability ( $M$ ) of the Damour River Basin, Lebanon (after Itani and others, 2021). 


\section{Summary}

Water availability for managed aquifer recharge (MAR) in Jordan, Lebanon, and surrounding areas was estimated by simulation using available geospatial information estimated from remote sensing and other information. Input from remote sensing included land surface elevation, which was processed to provide hydrologic flow directions and runoff accumulation in stream channels. Data were compiled from available remote sensing datasets to construct daily model inputs for the period from 1984 to 2015. A simple bucket model simulated the available runoff for each 500-m model pixel in the regional model domain from daily precipitation and simulated evapotranspiration (ET) based on reference (potential) ET, temperature, simulated soil moisture, and the average daily Normalized Difference Vegetation Index (NDVI) for the period 2001-15. The model simulated soil moisture dynamics and runoff included surface runoff and deep drainage (recharge), partitioned using a runoff coefficient. Accumulated runoff was computed at $30-\mathrm{m}$ resolution by adding the volumetric runoff from all model cells within each cell's drainage area, which was determined from the land surface digital elevation model (DEM).

Regional screening suitability maps were developed to illustrate methods for map preparation using only available regional data on surface slope and water availability. The surface slope was computed from a 30-m DEM of the study area. The water availability was simulated by Senay and others (2021). The two methods used were (1) tabular classification and combined ranking and (2) Multi-Criteria Decision Analysis (MCDA) with Analytic Hierarchy Process (AHP) pairwise comparison weighted sum scoring. Both methods produce similar regional screening maps with the main difference a result of modifications not directly related to the alternative methods: the size of the suitable zone along streams and exclusion of the lowest runoff class. In terms of slope and runoff, regional suitability is limited in Lebanon owing to steep slopes, whereas in Jordan regional suitability is limited owing to water availability. However, suitable areas, in terms of these two factors, at the regional scale, do appear to be present in many locations in Lebanon, Jordan, and the surrounding region.

A Jordanian project team examined the potential for MAR in the lower Jordan Valley, Jordan. Factors important for evaluating the suitability for capture of flood runoff included water availability from simulation and streamflow records, groundwater quality, the hydrogeologic characteristic allowing captured water to infiltrate to the aquifer, available storage for the MAR volume, and opportunities for withdrawal and use either locally or through available infrastructure. A heuristic weighting and overall scoring produced a four-level ranking of subareas ranging from not suitable to high suitability. High suitability areas included alluvial fan deposits along the valley margins, which may be widespread but difficult to locate given the geologic history of the rift valley.

A Lebanese project team mapped the suitability of MAR in the Damour River Basin along the coast of Lebanon using a more explicit procedure to score and weight factors related to MAR suitability. Formal and explicit MCDA with AHP pairwise comparison weighting allowed a suitability score to be computed based on a total of nine different characteristics of the study area, ranging from the slope of the land surface to the level of aquifer stress. The suitability score was an equally weighted sum of three first-level factors: water availability, aquifer rechargeability, and socioeconomic benefits. Each of those first-level factors was in turn a weighted sum of second-level factors. Although the procedure is explicit and transparent, subjectivity was required at several steps in the suitability mapping process: in selecting factors, classification and scoring of factors, and weighting those scores for a final MAR suitability score. As with the Jordan case study, several areas within the Damour River Basin were mapped as suitable for use of MAR to improve water supply. They were generally located alongside the main stream channels for high water availability, where the lower land-surface slope could accommodate infiltration infrastructure, and where MAR could provide high socioeconomic benefits for water quality management and supply storage. 


\section{References Cited}

Abdallat, G., Harahshah, E., and Salameh, E., 2020, Management of treated wastewater and flood water using GIS for environmental protection in Jordan: Journal of Geoscience and Environment Protection, v. 8, no. 1, p. 86-100, accessed June 13, 2021, at https://doi. org/10.4236/gep.2020.81006.

Abdallat, G., and Salameh, E., 2019, Mixing of waters and water-rock interaction processes during managed aquifer recharge [abs.]: 10th International Symposium on Managed Aquifer Recharge, Madrid, Spain, p. 111, accessed January 7, 2020, at https://www.ismar10.net/en/2019/05/18/ismar10abstracts-book-and-program/.

Abdo, G.M., and Eldaw, A.K., 2006, Water harvesting experience in the Arab world, in Neupane, B., ed., Regional Workshop on Management of Aquifer Recharge and Water Harvesting in Arid and Semi-Arid Regions of Asia - 27th November -1st December 2004, Yazd, Republic of Islamic Iran: New Dehli, Oxford \& IBH Publishing Company, p. 79-95, accessed February 11, 2021, at https:/www. researchgate.net/publication/292725885_Water-harvesting_ experience_in_the_Arab_region.

Aiken, G.R., and Kuniansky, E.L., 2002, U.S. Geological Survey artificial recharge workshop proceedings, Sacramento, California, April 2-4, 2002: U.S. Geological Survey Open-File Report 02-89, 88 p., accessed August 16, 2021, at https://water.usgs.gov/ogw/pubs/ofr0289/.

Al-Assa'd, T.A., and Abdulla, F.A., 2010, Artificial groundwater recharge to a semi-arid basin-Case study of Mujib aquifer, Jordan: Environmental Earth Sciences, v. 60, no. 4, p. 845-859, accessed June 13, 2021, at https://doi. org/10.1007/s12665-009-0222-2.

Alesheikh, A.A., Soltani, M.J., Nouri, N., and Khalilzadeh, M., 2008, Land assessment for flood spreading site selection using geospatial information system: International Journal of Environmental Science and Technology, v. 5, no. 4, p. 455-462, accessed August 16, 2021, at https://doi. org/10.1007/BF03326041.

Allen, R.G., Pereira, L.S., Raes, D., and Smith, M., 1998, Crop evapotranspiration - Guidelines for computing crop water requirements: Food and Agriculture Organization of the United Nations, FAO Irrigation and Drainage Paper 56, accessed June 20, 2021, at http://www.fao.org/3/x0490e/ x0490e00.htm.
Allewijn, R., 1990, Remote sensing and runoff modelling in alpine areas - A Landsat-supported conceptual semidistributed rainfall-runoff model, applied to the N-Italian Alps: Meetkundige Dienst, Amsterdam, Delft \& Vrije Universiteit, $176 \mathrm{p}$.

Alraggad, M., and Jasem, H., 2010, Managed aquifer recharge (MAR) through surface infiltration in the Azraq basin/ Jordan: Journal of Water Resource and Protection, v. 2, no. 12, p. 1057-1070, accessed August 16, 2021, at https:// doi.org/10.4236/jwarp.2010.212125.

Arab Resources Development, 2003, Integrated water resources management in CAMP area with demonstrations in Damour, Sarafand and Naqoura municipalities: Arab Resources Development, Final report, 132 p., accessed August 17, 2021, at https://iczmplatform.org/storage/documents/ nGrggv1OTDPwEH1n7bP59ojbMIMNwxEJaYTThxFh. pdf.

Avisse, N., Tilmant, A., Rosenberg, D., and Talozi, S., 2020, Quantitative assessment of contested water uses and management in the conflict-torn Yarmouk River Basin: Journal of Water Resources Planning and Management, v. 146, no. 7, p. 05020010, accessed August 16, 2021, at https://doi.org/10.1061/(ASCE)WR.1943-5452.0001240.

Bandel, K., and Salameh, E., 2013, Geologic development of Jordan-Evolution of its rocks and life: University of Jordan Press, 277 p., accessed June 1, 2020, at https:// www.researchgate.net/publication/275946617_Geologic Development_of_Jordan_-Evolution_of_its_Rocks_and_ Life.

Beak, D., Borst, M., Acree, S., Ross, R., Forshay, K., Ford, R., Huang, J., Su, C., Brumley, J., Chau, A., and Richardson, C., 2020, Influence of stormwater management practices and wastewater infiltration on groundwater quality - Case studies: U.S. Environmental Protection Agency, Report EPA/600/R-20/143, accessed June 19, 2021, at https:/nepis. epa.gov/Exe/ZyPURL.cgi?Dockey=P1010V6V.txt.

Beck, H.E., van Dijk, A.I.J.M., Levizzani, V., Schellekens, J., Miralles, D.G., Martens, B., and de Roo, A., 2017, MSWEP - 3-hourly $0.25^{\circ}$ global gridded precipitation (1979-2015) by merging gauge, satellite, and reanalysis data: Hydrology and Earth System Sciences, v. 21, no. 1, p. 589-615, accessed August 16, 2021, at https://doi. org/10.5194/hess-21-589-2017.

Bender, F., 1968, Geologie von Jordanien: Gebrüder Burntrãger, Berlin, 230 p.

Bender, F., 1975, Geology of the Arabian Pennisula, Jordan: U.S. Geological Survey Professional Paper 560-I, 136 p., 3 plates, https://doi.org/10.3133/pp560I. 
Beven, K., 1993, Prophecy, reality and uncertainty in distributed hydrological modelling: Advances in Water Resources, v. 16, no. 1, p. 41-51, accessed August 16, 2021, at https://doi.org/10.1016/0309-1708(93)90028-E.

Burrough, P.A., 1986, Principles of geographical information systems for land resources assessment: Oxford, Clarendon Press, 193 p. [Also available at https://doi. org/10.1080/10106048609354060.]

Burrough, P.A., and McDonnell, R.A., 1998, Principles of geographical information systems: Oxford, Oxford University Press, 190 p., accessed August 21, 2017, at https://www.researchgate.net/publication/37419765 Principle_of_Geographic_Information_Systems.

CDM Smith Inc., 2012, 2012 Guidelines for water reuse: U.S. Environmental Protection Agency, EPA/600/R-12/618, 643 p., accessed on April 15, 2020, at https://nepis.epa.gov/ Adobe/PDF/P100FS7K.pdf.

Central Ground Water Board, 2007, Manual of artificial recharge of ground water - Gov. of India: New Delhi, Ministry of Water Resources, 185 p., accessed on August 16, 2021, at http://cgwb.gov.in/documents/Manual\%20 on $\% 20$ Artificial $\% 20$ Recharge $\% 20$ of $\% 20$ Ground $\% 20$ Water. pdf.

Daher, W., 2011, Étude de faisabilité de recharge artificielle dans un aquifère karstique côtier: Beirut, Saint-Joseph University, Ph.D. dissertation, 214 p., accessed August 17, 2021, at http://www.theses.fr/2011MON20226/document.

Daher, W., Pistre, S., Kneppers, A., Bakalowicz, M., and Najem, W., 2011, Karst and artificial recharge-Theoretical and practical problems; A preliminary approach to artificial recharge assessment: Journal of Hydrology (Amsterdam), v. 408 , no. 3-4, p. 189-202, accessed August 17, 2021, at https://doi.org/10.1016/j.jhydrol.2011.07.017.

Damaj, A., 2019, Drivers and barriers towards nature based solutions for water management in Beirut, Lebanon: Rotterdam, Erasmus University Rotterdam, Institute for Housing and Urban Development Studies, M.S. thesis, 84 p.

Daud, A., 1972, Ground water recharge in the Beirut area: Beirut, American University of Beirut, M.S. thesis, 66 p.

de Laat, P.J.M., and Nonner, J.C., 2012, Artificial recharge with surface water; a pilot project in Wadi Madoneh, Jordan: Environmental Earth Sciences, v. 65, p. 1251-1263, accessed August 17, 2021, at https://doi.org/10.1007/ s12665-011-1372-6.

Didan, K., 2015, MOD13Q1 MODIS/Terra vegetation indices 16-day L3 global 250m SIN grid V006: National Aeronautics and Space Administration EOSDIS Land Processes DAAC web page, accessed June 3, 2021, at https://doi.org/10.5067/MODIS/MOD13Q1.006.
Dillon, P., Stuyfzand, P., Grischek, T., Lluria, M., Pyne, R.D.G., Jain, R.C., Bear, J., Schwarz, J., Wang, W., Fernandez, E., Stefan, C., Pettenati, M., van der Gun, J., Sprenger, C., Massmann, G., Scanlon, B.R., Xanke, J., Jokela, P., Zheng, Y., Rossetto, R., Shamrukh, M., Pavelic, P., Murray, E., Ross, A., Bonilla Valverde, J.P., Palma Nava, A., Ansems, N., Posavec, K., Ha, K., Martin, R., and Sapiano, M., 2019, Sixty years of global progress in managed aquifer recharge: Hydrogeology Journal, v. 27, no. 1, p. 1-30, accessed August 17, 2021, at https://doi. org/10.1007/s10040-018-1841-z.

Dillon, P., Page, D., Dandy, G., Leonard, R., Tjandraatmadja, G., Vanderzalm, J., Rouse, K., Barry, K., Gonzalez, D., and Myers, B., 2014, Managed aquifer recharge and urban stormwater use options-Summary of research findings: Goyder Institute for Water Research, Technical Report Series no. 14/13, 42 p., accessed July 8, 2021, at https:// publications.csiro.au/rpr/download?pid=csiro:EP145741\&d sid=DS5.

Dottridge, J., 1998, Water resources quality, sustainability and development, chap. 4 of Dutton, R.W., Clarke, J.I., and Battikhi, A.M., eds., Arid Land Resources and Their Management—Jordan's Desert Margin: London, Kegan Paul International, p. 67-79.

Dutton, R.W., Clarke, J.I., and Battikhi, A.M., eds., 1998, Arid land resources and their management-Jordan's desert margin: London, Jordan Badia Research and Development Programme, Kegan Paul International, 332 p.

Edworthy, K., 2001, Options for artificial groundwater recharge with reclaimed water in Amman-Zarqa basin \& Jordan Valley: Associates in Rural Development Inc., project report for U.S. Agency for International Development, 44 p., accessed January 30, 2017, at https:// pdf.usaid.gov/pdf_docs/PNACP561.pdf.

El-Samra, R., Bou-Zeid, E., Bangalath, H.K., Stenchikov, G., and El-Fadel, M., 2017, Future intensification of hydrometeorological extremes-Downscaling using the weather research and forecasting model: Climate Dynamics, v. 49, no. 11-12, p. 3765-3785, accessed August 17, 2021, at https://doi.org/10.1007/s00382-017-3542-z.

El-Samra, R., Bou-Zeid, E., and El-Fadel, M., 2018, To what extent does high-resolution dynamical downscaling improve the representation of climatic extremes over an orographically complex terrain?: Theoretical and Applied Climatology, v. 134, no. 1-2, p. 265-282, accessed August 17, 2021, at https://doi.org/10.1007/s00704-017-2273-8.

Fick, S.E., and Hijmans, R.J., 2017, WorldClim 2-New 1 $\mathrm{km}$ spatial resolution climate surfaces for global land areas: International Journal of Climatology, v. 37, no. 12, p. 43024315, accessed June 3, 2021, at https://www.worldclim.org/ data. 
Gale, I., 2005, Strategies for managed aquifer recharge (MAR) in semi-arid areas: UNESCO, IHP/2005/GW/MAR, 30 p., accessed August 17, 2021, at https://unesdoc.unesco.org/ ark:/48223/pf0000143819.

Goode, D.J., Senior, L.A., Subah, A., and Jaber, A., 2013, Groundwater-level trends and forecasts, and salinity trends, in the Azraq, Dead Sea, Hammad, Jordan Side Valleys, Yarmouk, and Zarqa groundwater basins, Jordan: U.S. Geological Survey Open-File Report 2013-1061, 80 p., accessed August 17, 2021, at https://doi.org/10.3133/ ofr20131061.

Gorski, G., 2021, Recharge suitability mapping for Jordan Valley: HydroShare web page, accessed July 9, 2021, at https://doi.org/10.4211/hs.e4c08ffba98746d7a8b3700723f2 $4 \mathrm{dcb}$.

Gorski, G., and van der Valk, M., 2019, Producing more interpretable maps of managed aquifer recharge suitability by visualizing sensitivity to subjective choices during mapmaking [abs.]: 10th International Symposium on Managed Aquifer Recharge, Madrid, Spain, p. 133, accessed January 7, 2020, at https://www.ismar10.net/ en/2019/05/18/ismar10-abstracts-book-and-program/.

Helms, S., 1981, Jawa-Lost city of the Black Desert: London, Methuen, $270 \mathrm{p}$.

Hlavaty, H., 2018, Review of water scarcity ranking methodologies: Report for USAID Water Management Initiative Contract No. AID-278-C-16-00001, 11 p., accessed March 21, 2021, at https://www.globalwaters.org/ sites/default/files/Review\%20of $\% 20$ Water $\% 20$ Scarcity $\% 20$ Ranking\%20Methodologies\%20-\%20Jordan\%20 Ranking\%20Brief.pdf.

Horowitz, A., 1979, The Quaternary of Israel: Academic Press, London, 410 p.

International Commission on Stratigraphy, 2021, International stratigraphic chart: International Commission on Stratigraphy web page, accessed August 13, 2021, at https:// stratigraphy.org/ICSchart/ChronostratChart2021-07.pdf.

Itani, N., Harik, G., Alameddine, I., and El-Fadel, M., 2021, Potential of managed aquifer recharge in Lebanon-A case study of the Damour watershed: Beirut, Lebanon, American University of Beirut, Department of Civil \& Environmental Engineering, 57 p., accessed May 12, 2021, at https://pdf. usaid.gov/pdf_docs/PA00XJG2.pdf.

Kagone, S., Velpuri, N.M., and Senay, G.B., 2021, Assembly of satellite-based rainfall datasets in situ data and rainfall climatology contours for the MENA region: U.S. Geological Survey data release, https://doi.org/10.5066/P971ZVHF.
Kazakis, N., 2018, Delineation of suitable zones for the application of managed aquifer recharge (MAR) in coastal aquifers using quantitative parameters and the analytical hierarchy process: Water, v. 10, no. 6, 22 p., accessed August 17, 2021, at https://doi.org/10.3390/w10060804.

Khadra, W.M., 2017, Analysis and remediation of the salinized, Damour coastal (dolomitic) limestone aquifer in Lebanon: Delft, Delft University of Technology, Ph.D. thesis, $211 \mathrm{p}$.

Khadra, W.M., and Stuyfzand, P.J., 2014, Separating baseline conditions from anthropogenic impacts - Example of the Damour coastal aquifer (Lebanon): Hydrological Sciences Journal, v. 59, no. 10, p. 1872-1893, accessed August 17, 2021, at https://doi.org/10.1080/02626667.2013.841912.

Khair, K., Aker, N., Haddad, F., Jurdi, M., and Hachach, A., 1994, The environmental impacts of humans on groundwater in Lebanon: Water, Air, and Soil Pollution, v. 78, p. 37-49.

Khair, K., Kassem, F., and Amacha, N., 2016, Factors affecting the discharge rate of the streams - case study; Damour River Basin, Lebanon: Journal of Geography, Environment and Earth Science International, v. 7, no. 2, 17 p., accessed August 17, 2021, at https://doi.org/10.9734/ JGEESI/2016/28027.

Kheir, K., and Akar, N., 1992, La sécurité hydrique dans les pays arabes: Egypte/Monde Arabe, v. 10, no. 10, p. 63-77, accessed August 17, 2021, at https://doi.org/10.4000/ ema.1412.

Kurtzman, D., and Guttman, J., 2020, Managed aquifer recharge with various water sources for irrigation and domestic use-A perspective of the Israeli experience, in Global Groundwater-Source, Scarcity, Sustainability, Security, and Solutions: Amsterdam, Elsevier, p. 597-608.

Lutz, J.A., van Wagtendonk, J.W., and Franklin, J.F., 2010, Climatic water deficit, tree species ranges, and climate change in Yosemite National Park: Journal of Biogeography, v. 37, no. 5, p. 936-950, accessed August 17, 2021, at https://doi.org/10.1111/j.1365-2699.2009.02268.x.

Malczewski, J., and Rinner, C., 2015, Multicriteria decision analysis in geographic information science: Berlin, Springer-Verlag, 331 p., accessed August 17, 2021, at https://doi.org/10.1007/978-3-540-74757-4.

Maliva, R.G., Missimer, T.M., Winslow, F.P., and Herrmann, R., 2011, Aquifer storage and recovery of treated sewage effluent in the Middle East: Arabian Journal for Science and Engineering, v. 36, p. 63-74. 
Massoud, M.A., 2012, Assessment of water quality along a recreational section of the Damour River in Lebanon using the water quality index: Environmental Monitoring and Assessment, v. 184, no. 7, p. 4151-4160, accessed August 17, 2021, at https://doi.org/10.1007/s10661-011-2251-z.

Ministry of Energy and Water and United Nations Development Program, 2014, Assessment of groundwater resources of Lebanon: United Nations Development Program Technical Report, 44 p., accessed July 1, 2021, at https://www.lb.undp.org/content/lebanon/en/home/library/ environment_energy/assessment-of-groundwater-resourcesof-lebanon/.

Ministry of Environment, 2010, State and trends of the Lebanese environment 2010: United Nations Development Program web page, 355 p., accessed July 8, 2019, at https:// www.lb.undp.org/content/dam/lebanon/docs/Energy $\% 20$ and\%20Environment/Publications/SOER_en.pdf.

Ministry of Water and Irrigation, 2016, National water strategy of Jordan, 2016-2025: Amman, Jordan, Ministry of Water and Irrigation, $56 \mathrm{p}$.

Ministry of Water and Irrigation, 2009, Water for life Jordan's water strategy 2008-2022: Amman, Jordan, Ministry of Water and Irrigation, $70 \mathrm{p}$.

Momejian, N., Abou Najm, M., Alameddine, I., and El-Fadel, M., 2019, Can groundwater vulnerability models assess seawater intrusion?: Environmental Impact Assessment Review, v. 75, p. 13-26, accessed August 17, 2021, at https://doi.org/10.1016/j.eiar.2018.10.003.

Moussavi, M., Wyseure, G., and Feyen, J., 1989, Estimation of melt rate in seasonally snow-covered mountainous areas: Hydrological Sciences Journal, v. 34, no. 3, p. 249-263, accessed August 17, 2021, at https://doi. org/10.1080/02626668909491333.

National Research Council, 1994, Groundwater recharge using waters of impaired quality: Washington, D.C., National Academy Press, 304 p.

Ortloff, C.R., 2005, The water supply and distribution system of the Nabataean city of Petra (Jordan), 300 BC-AD 300:

Cambridge Archaeological Journal, v. 15, no. 1, p. 93-109, accessed August 17, 2021, at https://doi.org/10.1017/ S0959774305000053.

Prinz, D., 2016, How to prevent sea water intrusion in coastal cities - Case study Beirut: Beirut, United Nations Economic and Social Commission for Western Asia, Beirut, 9 p., accessed August 17, 2021, at http://riccar.org/sites/ default/files/riccar/ADAPTATION\%20NODE/Pdfs/1.\%20 Adaptation\%20Policies/5\%20Policy\%20Brief-How\%20 to $\% 20$ Prevent $\% 20$ Seawater\%20Intrusion $\% 20$ in $\% 20$ Coastal\%20Cities\%20-\%20Case $\% 20$ Study $\% 20$ Beirut $\%$ 2C\%20Lebanon.pdf.
Rahman, K., Gorelick, S.M., Dennedy-Frank, P.J., Yoon, J., and Rajaratnam, B., 2015, Declining rainfall and regional variability changes in Jordan: Water Resources Research, v. 51, no. 5, p. 3828-3835, accessed August 17, 2021, at https://doi.org/10.1002/2015WR017153.

Ringleb, J., Sallwey, J., and Stefan, C., 2016, Assessment of managed aquifer recharge through modeling - A review: Water (Basel), v. 8, no. 12, 31 p., accessed August 17, 2021, at https://doi.org/10.3390/w8120579.

Rolf, L., 2017, Assessing the site suitability of managed aquifer recharge (MAR) projects in karst aquifers in Lebanon-A multi criteria analysis: Utrecht, Netherlands, Utrecht University, M.S. thesis, 146 p., accessed August 17, 2021, at http://dspace.library.uu.nl/handle/1874/352931.

Rosenberg, D.E., and Peralta, R., 2012, Economic impacts of groundwater drawdown in Jordan: International Resources Group report for U.S. Agency for International Development contract EPP-I-00-04-00024-00, 29 p.

Saadeh, M., and Wakim, E., 2017, Deterioration of groundwater in Beirut due to seawater intrusion: Journal of Geoscience and Environment Protection, v. 5, no. 11, p. 149-159, accessed August 17, 2021 at https://doi. org/10.4236/gep.2017.511011.

Saaty, T.L., 1980, The analytic hierarchy process: New York, McGraw-Hill, $287 \mathrm{p}$.

Salameh, E., and Abdallat, G., 2020a, Potential areas for managed aquifer recharge in the eastern lower Jordan Valley area: Journal of Water Resource and Protection, v. 12, no. 04 , p. 330-357, accessed July 9, 2021, at https://doi. org/10.4236/jwarp.2020.124020.

Salameh, E., and Abdallat, G., 2020b, The potential for groundwater artificial recharge-With a case study in the Jordan Valley area: Amman, Jordan, National Center for Research and Development, 22 p., accessed July 9, 2021, at https://pdf.usaid.gov/pdf_docs/PA00X32Z.pdf.

Salameh, E., Abdallat, G., and Van der Valk, M., 2019a, Planning considerations of managed aquifer recharge (MAR) projects in Jordan: Water (Basel), v. 11, no. 2, p. 182, accessed January 7, 2020, at https://doi.org/10.3390/ w11020182.

Salameh, E., Goode, D.J., and Abdallat, G., 2019b, Unsustainable depletion of non-renewable groundwater accelerating - the Jordan case [abs.]: American Geophysical Union Chapman Conference on the Quest for Sustainability of Heavily Stressed Aquifers at Regional to Global Scales, October 21-24, 2019, Valencia, Spain, accessed online January 7, 2020, at https://agu.confex.com/ agu/19chapman5/meetingapp.cgi/Paper/487943. 
Sallwey, J., Bonilla Valverde, J.P., Vásquez López, F., Junghanns, R., and Stefan, C., 2019a, Suitability maps for managed aquifer recharge-A review of multi-criteria decision analysis studies: Environmental Review, v. 27, no. 2, p. 138-150, accessed August 17, 2021, at https://doi. org/10.1139/er-2018-0069.

Sallwey, J., Schlick, R., Bonilla Valverde, J.P., Junghanns, R., Vásquez López, F., and Stefan, C., 2019b, Suitability mapping for managed aquifer recharge-Development of web-tools: Water, v. 11, no. 2254, 11 p., accessed August 17, 2021, at https://doi.org/10.3390/w11112254.

Senay, G.B., 2008, Modeling landscape evapotranspiration by integrating land surface phenology and a water balance algorithm: Algorithms, v. 1, no. 2, p. 52-68, accessed August 17, 2021, at https://doi.org/10.3390/a1020052.

Senay, G.B., Kagone, S., Velpuri, N.M., and Goode, D.J., 2021, Modeling accumulated surface runoff and water availability for aquifer storage and recovery in the MENA region from 1984-2015: U.S. Geological Survey data release, https://doi.org/10.5066/P9TXLT1X.

Senay, G.B., and Verdin, J., 2003, Characterization of yield reduction in Ethiopia using a GIS-based crop water balance model: Canadian Journal of Remote Sensing, v. 29, no. 6, p. 687-692, accessed August 17, 2021, at https://doi. org/10.5589/m03-039.

Senay, G., Verdin, J., Lietzow, R., and Melesse, A.M., 2008, Global daily reference evapotranspiration modeling and evaluation 1: Journal of the American Water Resources Association, v. 44, no. 4, p. 969-979, accessed August 17, 2021, at https://doi.org/10.1111/j.1752-1688.2008.00195.x.

Shaban, A., 2009, Indicators and aspects of hydrological drought in Lebanon: Water Resources Management, v. 23, no. 10, p. 1875-1891, accessed August 17, 2021, at https:// doi.org/10.1007/s11269-008-9358-1.

Shaban, A., 2011, Analyzing climatic and hydrologic trends in Lebanon: Journal of Environmental Science \& Engineering, v. 5 , no. 4 , p. $483-492$.

Shahinuzzaman, M., Nozibul Haque, M., and Shahid, S., 2021, Delineation of groundwater potential zones using a parsimonious concept based on catastrophe theory and analytical hierarchy process: Hydrogeology Journal, v. 29, no. 3, p. 1091-1116, accessed August 16, 2021 at https:// doi.org/10.1007/s10040-021-02322-2.

Steinel, A., Schelkes, K., Volk, A., and Subah, A., 2012, Guideline for assessment and implementation of Managed Aquifer Recharge (MAR) in (semi-)arid regions-Prefeasibility study for infiltration of floodwater in the Amman-Zarqa and Azraq basins, Jordan: BGR Technical Cooperation Project No. 2002.3510.1 GeoSFF Study Managed Aquifer Recharge in Jordan, 198 p.
Tercek, M., and Rodman, A., 2016, Forecasts of 21st century snowpack and implications for snowmobile and snowcoach use in Yellowstone National Park: PLoS One, v. 11, no. 7, p. e0159218, accessed August 17, 2021, at https://doi. org/10.1371/journal.pone.0159218.

Thornton, J., ed., 2001, Sourcebook of alternative technologies for freshwater augmentation in west Asia: United Nations Environment Program, 348 p.

Todd, D.K., 1959, Annotated bibliography on artificial recharge of ground water through 1954: U.S. Geological Survey Water-Supply Paper 1477, 115 p.

United Nations Development Program, 1970, Liban, Étude des Eaux Souterraines: New York, United Nations, 185 p.

Urban, T.M., Bocancea, E., Vella, C., Herringer, S.N., Alcock, S.E., and Tuttle C.A., 2013, Investigating ancient dams in Petra's northern hinterland with ground-penetrating radar: The Leading Edge, v. 32, no. 2, p. 121-232, accessed August 17, 2021, at https://doi.org/10.1190/tle32020190.1.

U.S. Agency for International Development, 2020, Water resources \& environment: U.S. Agency for International Development web page, accessed April 15, 2020, at https:// www.usaid.gov/jordan/water-and-wastewater-infrastructure.

U.S. Geological Survey, 2017, USGS EROS archive - Digital elevation - Shuttle Radar Topography Mission (SRTM) 1 arc-second global: U.S. Geological Survey web page, accessed June 7, 2017, at https://www.usgs.gov/centers/ eros/science/usgs-eros-archive-digital-elevation-shuttleradar-topography-mission-srtm-1-arc.

U.S. Geological Survey, 2021, USGS FEWS NET Data Portal: U.S. Geological Survey web page, accessed June 3, 2021, at https://earlywarning.usgs.gov/fews/datadownloads/Global/ PET.

Van Lidth de Jeude, E., 2016, Managed aquifer rechargeOpportunities and barriers: Utrecht, Netherlands, Utrecht University, M.S. thesis, 146 p.

Van der Valk, M.R., 1992, The Camcor River, Ireland-A hydrological reconnaisance survey using GIS and remote sensing: Amsterdam, Vrije Universiteit, 165 p.

Van der Valk, M., 1995, Toelichting op de kwel- en infiltratiekaart (Explanatory notes to the groundwater discharge and recharge map): Provincie Utrecht, Utrecht, 12 p. and 1 map.

Van Steenbergen, F., 2009, Managing the water buffer for development and climate change adaptation-Groundwater recharge, retention, reuse and rainwater storage: Utrecht, MetaMeta, Wageningen, CPWC, Delft \& The Netherlands National Committee IHP-HWRP, 92 p. 
Viollet, P.-L., 2000, L'hydraulique dans les civilisations anciennes — 5 000 ans d'histoire: Paris, Presses de l'École nationale des ponts et chaussées, $374 \mathrm{p}$.

Weeks, E., ed., 2003, Historical references for artificial recharge studies in the U.S. Geological Survey: U.S. Geological Survey web page, accessed February 11, 2021, at https://water.usgs.gov/ogw/recharge/.

World Resources Institute, 2021, Aqueduct water risk atlas: World Resources Institute web page, accessed August 13, 2021, at https://www.wri.org/applications/aqueduct/waterrisk-atlas/.

Xanke, J., Goeppert, N., Sawarieh, A., Liesch, T., Klinger, J., Ali, W., Hötzl, H., Hadidi, K., and Goldscheider, N., 2015, Impact of managed aquifer recharge on the chemical and isotopic composition of a karst aquifer, Wala reservoir, Jordan: Hydrogeology Journal, v. 23, no. 5, p. 1027-1040, accessed June 13, 2021, at https://doi.org/10.1007/s10040015-1233-6.
Yoon, J., Klassert, C., Selby, P. Lachaut, T., Knox, S., Avisse, N., Harou, J., Tilmant, A., Klauer, B., Mustafa, D., Sigel, K., Talozi, S., Gawel, E., Medellín-Azuara, J., Bataineh, B., Zhang, H., and Gorelick, S.M., 2021, A coupled human-natural system analysis of freshwater security under climate and population change: Proceedings of the National Academy of Sciences, v. 118, no. 14, e2020431118, accessed July 9, 2021, at https://doi.org/10.1073/ pnas. 2020431118.

Zaki, A., Al-Weshah, R., and Abdulrazzak, M., 2006, Water harvesting techniques in the Arab region: Proceedings of the UNESCO/G-WADI Workshop on Water Harvesting, November 20-22, 2006, Aleppo, Syria, p. 139-154. 


\section{Appendix 1. Project Activities for Acceleration of Aquifer Storage and Recovery in the Middle East and North Africa Region}

At the request of the U.S. Agency for International Development (USAID), the U.S. Geological Survey (USGS) led a multinational project "Acceleration of Aquifer Storage and Recovery in the Middle East and North Africa Region" from September 2016 through August 2021. The project was initiated and overseen by USAID Middle East Bureau in Washington, D.C. as part of a Middle East Water Security Initiative. Project teams were established at a USAID-facilitated workshop in Frankfurt, Germany in 2015. On behalf of USAID, USGS implemented the project and provided grant funding to project partners established at the Frankfurt workshop. This appendix provides a timeline of project activities, a list of project participants, and a list of project publications.

\section{Timeline}

- 2015

- November - USAID Middle East Water Security Initiative Workshop, Frankfurt, Germany

- 2016

- September - USAID/USGS Acceleration of Aquifer Storage and Recovery Project start

- 2017

- March - Project Kick-Off Meeting, Dead Sea, Jordan

- December - Regional Workshop 1, Amsterdam, the Netherlands

- 2018

- May - Remote Sensing \& Hydrology Symposium (RSHS18), Cordoba, Spain

- 2019

- January - Regional Workshop 2, Nicosia, Cyprus, with field trip (fig. 1.1)

- May - International Symposium on Managed Aquifer Recharge (ISMAR10), Madrid, Spain, with field trip (fig. 1.2)

- 2020

- January - Regional Workshop 3, Nicosia, Cyprus

- 2021

- August - Project reporting and completion 


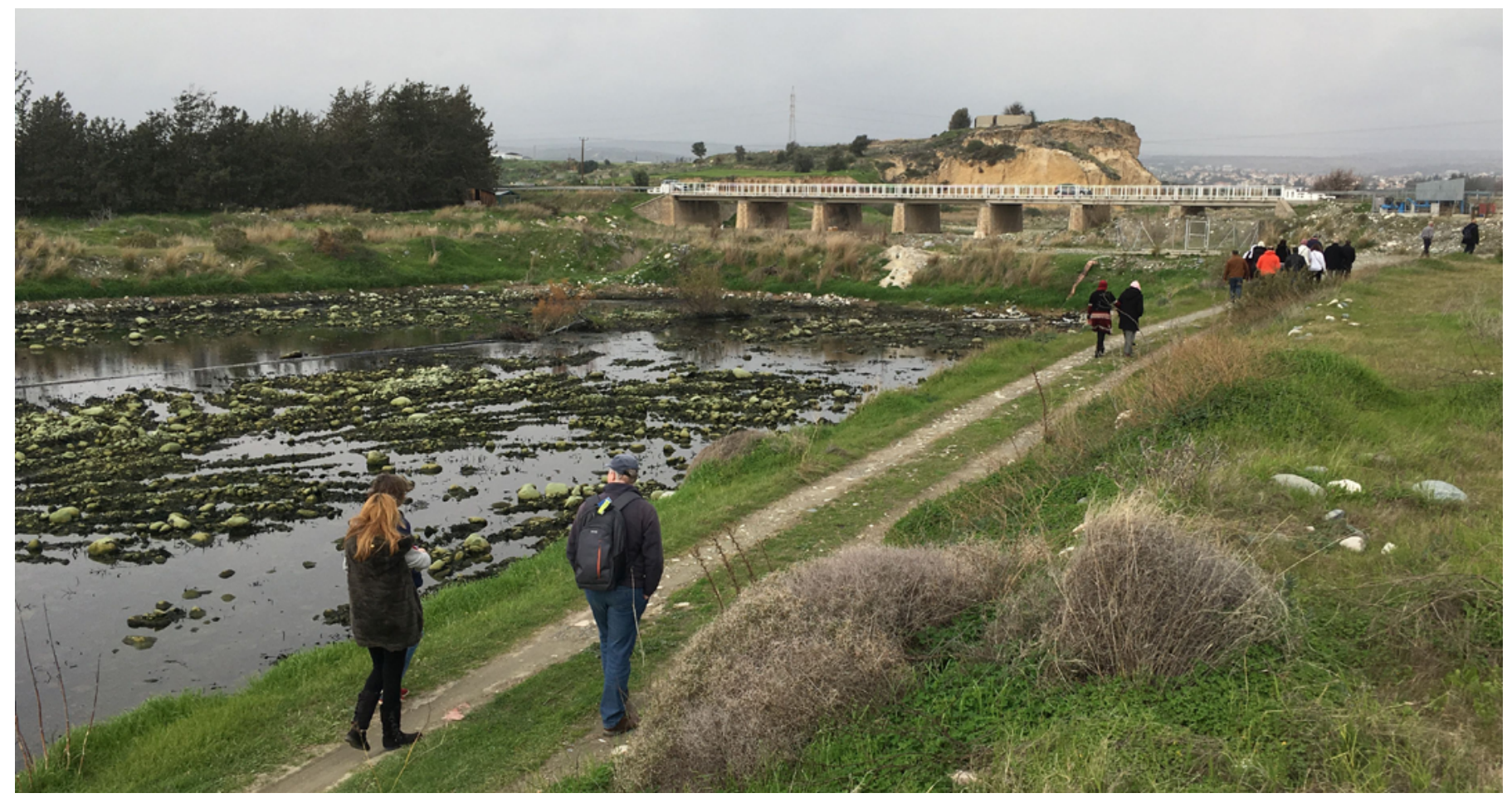

Figure 1.1. Managed aquifer recharge infiltration basin for treated wastewater in Cyprus. Photograph by Daniel J. Goode, U.S. Geological Survey.

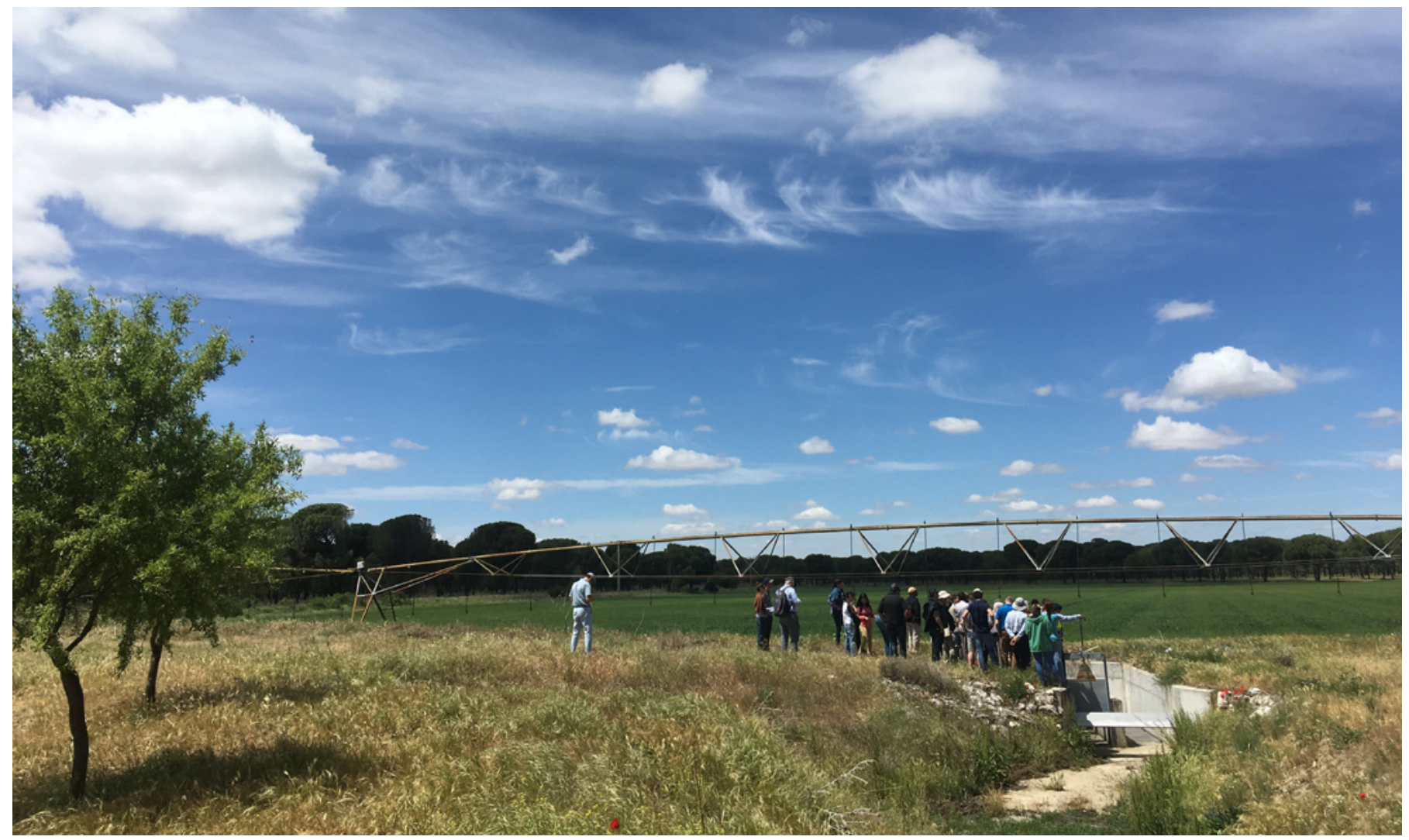

Figure 1.2. Infrastructure for agricultural reuse of artificially recharged groundwater in Spain. Photograph by Daniel J. Goode, U.S. Geological Survey. 


\section{Participants}

\section{Project Team}

U.S. Agency for International Development

- Sonia Massis

- John Wilson

- Kamal Ouda

\section{U.S. Geological Survey}

Overall project coordination, remote sensing and water availability estimation, suitability mapping, facilitate grant funding to project team partners, final report

- Daniel J. Goode

- Jack Eggleston

- Gabriel Senay

- N. Manohar Velpuri

- Stefanie Kagone

- Jeffrey Cole

\section{American University of Beirut}

Lebanon study area implementation, site evaluation, report, stakeholder engagement

- Mutasem El-Fadel

- Nour Alhouda Itani

- Ghinwa Harik

- Ibrahim Alameddine

\section{An-Najah National University (Nablus; 2016-2018)}

West Bank study area implementation (curtailed in January 2019)

- Shehdeh Joudeh

- Ghadir Hanbali

- Mohammed Hmidat

\section{Arab Water Council}

Organize and host workshops and project meetings, support suitability mapping and data compilation

- Heba Al-Hariry

- Noura Hany ElHariry

- Sherine Youssef 
- Menna Ghonaim

- Hussein El-Atfy

- Mervat Hassan

Hydrology.NL

Suitability mapping and hydrologic analyses, report preparation, capacity building

- Michael van der Valk

- Jacobus Groen

- Nanor Momjian

National Center for Research and Development (Jordan)

Jordan study area implementation, site evaluation, report, stakeholder engagement

- Elias Salameh

- Ghaida Abdallat

\section{Participating Stakeholders}

Litani River Authority - Lebanon

- Fadi Doumit

Ministry of Equipment, Logistics, Transport and Water-Morocco

- Nazha Sadiqi

- Taha El Ghazlani

Ministry of Water and Irrigation - Jordan

- Ali Subah

- Thair Al-Momani

Palestinian Water Authority (2016-2018)

- Deeb Abdulghafour

- Salaam Abu Hantash

- Omar Zayed

- Alaa Masri

- Subhi Samhan 


\section{Cooperators}

\section{University of California, Santa Cruz}

National Science Foundation Graduate Research Internship Program, decision support tool for managed aquifer recharge suitability mapping

- Galen Gorski

\section{The Cyrus Institute, Nicosia}

Technical exchange, field trips, and hosting of project workshop activities

- Adriana Bruggeman

- Hakan Djuma

- Ioannis Sofokleous

University of Jordan, and Inter-Islamic Network on Water Resources Development and Management Technical and illustration support for Jordan study area

- Marwan Alraggad

\section{Vrije Universiteit/VU University, Amsterdam, The Netherlands}

Hosting of project workshop activities

\section{Water Development Department, Ministry of Agriculture, Rural Development and Environment,} Cyprus

Technical exchange, field trip

- Charalambos Demitriou

- Maria Achilleos

\section{Waternet (Amsterdam water utility), The Netherlands}

Technical exchange, field trip, and hosting of project workshop activities

- Pierre Kamps

- Helen Perquin

- Frank Smits

- Han Dolman

- Fenny Bosse 


\section{Publications}

\section{Study Area Reports}

Itani, N., Harik, G., Alameddine, I., and El-Fadel, M., 2021, Potential of managed aquifer recharge in Lebanon-A case study of the Damour watershed: Beirut, Lebanon, American University of Beirut, Department of Civil \& Environmental Engineering, 57 p., https://pdf.usaid.gov/pdf_docs/PA00XJG2.pdf.

Salameh, E., and Abdallat, G., 2020, The potential for groundwater artificial recharge-With a case study in the Jordan Valley area: Amman, Jordan, National Center for Research and Development, 22 p., https://pdf.usaid.gov/pdf_docs/PA00X32Zpdf.

\section{Journal Articles}

Abdallat, G., Harahshah, E., and Salameh, E., 2020, Management of treated wastewater and flood water using GIS for environmental protection in Jordan: Journal of Geoscience and Environment Protection, v. 8, no. 01, p. 86-100. [Also available at https://doi.org/10.4236/gep.2020.81006.]

Al-Batsh, N., Al-Khatib, I.A., Ghannam, S., Anayah, F., Jodeh, S., Hanbali, G., Khalaf, B., and van der Valk, M., 2019, Assessment of rainwater harvesting systems in poor rural communities-A case study from Yatta area, Palestine: Water (Basel), v. 11, no. 3, p. 585. [Also available at https://doi.org/10.3390/w11030585.]

Al-Khatib, I.A., Arafeh, G.A., Al-Qutob, M., Jodeh, S., Hasan, A.R., Jodeh, D., and Van der Valk, M., 2019, Health risk associated with some trace and some heavy metals content of harvested rainwater in Yatta area, Palestine: Water (Basel), v. 11, no. 2, p. 238. [Also available at https://doi.org/10.3390/w11020238.]

Kagone, S., Velpuri, N.M., Khand, K., Senay, G.B., Goode, D.J., Abu Hantash, S., Al-Momani, T., Momejian, N., Van der Valk, M.R., and Eggleston, J., (in prep.), Modeling regional rainfall dataset using satellite-based rainfall observations, in situ data and rainfall climatology contours-A case study in the MENA region: Journal of Arid Environments (for submission to Journal of Arid Environments).

Salameh, E., and Abdallat, G., 2020, Potential areas for managed aquifer recharge in the eastern lower Jordan Valley area: Journal of Water Resource and Protection, v. 12, no. 04, p. 330-357. [Also available at https://doi.org/10.4236/ jwarp.2020.124020.]

Salameh, E., Abdallat, G., and van der Valk, M., 2019, Planning considerations of managed aquifer recharge (MAR) projects in Jordan: Water (Basel), v. 11, no. 2, p. 182. [Also available at https://doi.org/10.3390/w11020182.]

\section{Conference Abstracts}

Abdallat, G., and Salameh, E., 2018, Water harvesting and groundwater artificial recharge in Jordan - Wadi Kafrain case study [abs.]: Remote Sensing and Hydrology Symposium (RSHS18), Cordoba, Spain, May 2018, no. 86.

Abdallat, G., and Salameh, E., 2019, Mixing of waters and water-rock interaction processes during managed aquifer recharge [abs.]: 10th International Symposium on Managed Aquifer Recharge, Madrid, Spain, p. 111. [Also available at https://www. ismar10.net/en/2019/05/18/ismar10-abstracts-book-and-program/.]

Gorski, G., and van der Valk, M., 2019, Producing more interpretable maps of managed aquifer recharge suitability by visualizing sensitivity to subjective choices during mapmaking [abs.]: 10th International Symposium on Managed Aquifer Recharge, Madrid, Spain, p. 133. [Also available at https://www.ismar10.net/en/2019/05/18/ismar10-abstracts-book-andprogram/.]

Harb, H., Jodeh, S., Rasem Hassan, A., Samhan, S., van der Valk, M., Hanbali, G., and Hmidat, M., 2019, Metals content, occurrence and distribution in soil of Al-Qilt catchment [abs.]: 10th International Symposium on Managed Aquifer Recharge, Madrid, Spain, p. 156. [Also available at https:/www.ismar10.net/en/2019/05/18/ismar10-abstracts-book-and-program/.] 
Salameh, E., Goode, D.J., and Abdallat, G., 2019, Unsustainable depletion of non-renewable groundwater accelerating-the Jordan case [abs.]: American Geophysical Union Chapman Conference on the Quest for Sustainability of Heavily Stressed Aquifers at Regional to Global Scales, Valencia, Spain, October 21-24, 2019. [Also available at https://agu.confex.com/ agu/19chapman5/meetingapp.cgi/Paper/487943.]

Senay, G.B., Kagone, S., Velpuri, N.M., Goode, D.J., and Eggleston, J., 2018, Satellite-derived actual evapotranspiration mapping for basin water budget assessment and drought monitoring applications [abs.]: Remote Sensing and Hydrology Symposium (RSHS18), Cordoba, Spain, May 2018, no. 69.

Senay, G.B., Kagone, S., Velpuri, N.M., Goode, D.J., Eggleston, J., and van der Valk, M.R., 2019, Integrating weather and remote sensing datasets for historical (1980-2015) runoff simulations and mapping in the MENA region [abs.]: 10th International Symposium on Managed Aquifer Recharge, Madrid, Spain, p. 77. [Also available at https://www.ismar10.net/ en/2019/05/18/ismar10-abstracts-book-and-program/.]

Van der Valk, M., Abdallat, G., Abu Hantash, S., Achilleos, M., Ghonaim, M., Hanbali, G., Hany, N., Harik, G., Hmidat, M., Itani, N.A., Momjian, N., and Gorski, G., 2019, The impact of MAR suitability mapping and maps as a tool in the sciencepolicy interface [abs.]: 10th International Symposium on Managed Aquifer Recharge, Madrid, Spain, p. 214. [Also available at https://www.ismar10.net/en/2019/05/18/ismar10-abstracts-book-and-program/.]

Velpuri, N.M., Senay, G.B., Goode, D.J., Eggleston, J., van der Valk, M.R., Abu Hantash, S., and Al-Momani, T., 2018, Modeling regional rainfall dataset using satellite based rainfall observations, in situ data and rainfall climatology contours - A case study for the MENA region [abs.]: Remote Sensing and Hydrology Symposium (RSHS18), Cordoba, Spain, May 2018, no. 38 .

Velpuri, N.M., Senay, G.B., Goode, D., Kagone, S., Abu Hantash, S., Momejian, N., Al-Momani, T., Van der Valk, M.R., and Eggleston, J., 2018, Validation of seven gridded rainfall products for the Jordan, Palestine, and Lebanon region using in situ observations [abs.]: American Geophysical Union 2018 Fall Meeting, H43F-2471. [Also available at https://agu.confex.com/ agu/fm18/meetingapp.cgi/Paper/394693.]

Velpuri, N.M., Senay, G.B., Kagone, S., Goode, D.J., Eggleston, J., and van der Valk, M.R., 2019, Mapping potential sites for aquifer storage and recovery in the MENA region-A hydrologic modeling and remote sensing approach [abs.]: 10th International Symposium on Managed Aquifer Recharge, Madrid, Spain, p. 76. [Also available at https://www.ismar10.net/ en/2019/05/18/ismar10-abstracts-book-and-program/.] 


\section{Appendix 2. Bedrock Geology of the Lower Jordan Valley, Jordan}

Table 2.1. Bedrock geologic formations of the eastern Jordan Valley escarpment, Jordan. Lithology, thicknesses, and hydrogeology from Salameh and Abdallat (2020a, b), Sir M MacDonald \& Partners and Hunting Technical Services Ltd (1965), Bender (1968, 1975), and Bandel and Salameh (2013).

[--, none]

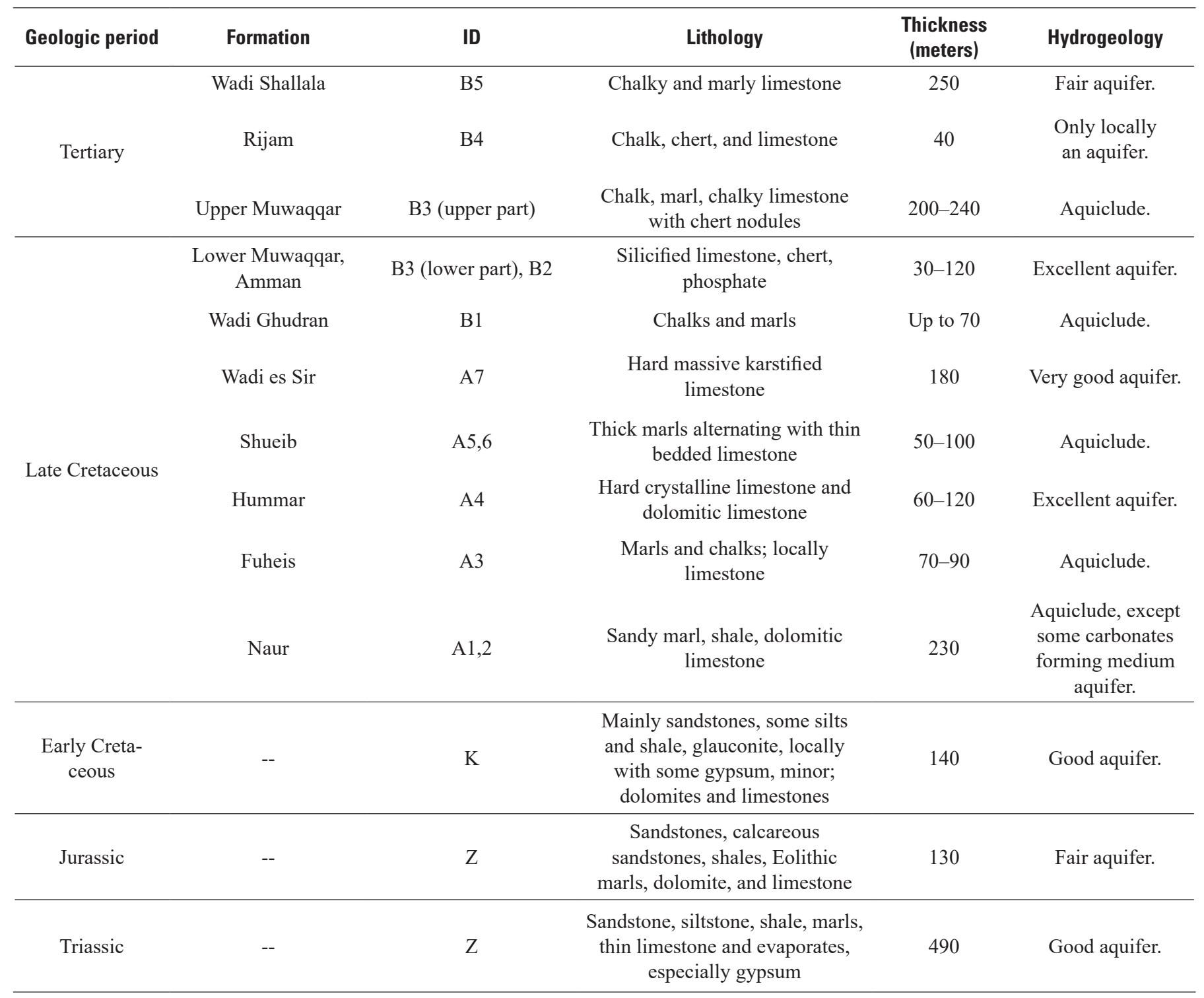




\title{
References
}

Bandel, K., and Salameh, E., 2013, Geologic development of Jordan -Evolution of its rocks and life: University of Jordan Press, 277 p. accessed June 1, 2020, at https://www.researchgate.net/publication/275946617_Geologic_Development_of_Jordan_-Evolution_of_its_Rocks_and_Life.

Bender, F., 1968, Geologie von Jordanien: Gebrüder Burntrãger, Berlin, 230 p.

Bender, F., 1975, Geology of the Arabian Pennisula, Jordan: U.S. Geological Survey Professional Paper 560-I, 136 p., 3 plates, accessed July 9, 2021, at https://doi.org/10.3133/pp560I.

Salameh, E., and Abdallat, G., 2020a, Potential areas for managed aquifer recharge in the eastern lower Jordan Valley area: Journal of Water Resource and Protection, v. 12, no. 04, p. 330-357, accessed July 9, 2021, at https://doi.org/10.4236/ jwarp.2020.124020.

Salameh, E., and Abdallat, G., 2020b, The potential for groundwater artificial recharge-With a case study in the Jordan Valley area: Amman, Jordan, National Center for Research and Development, 22 p., accessed July 9, 2021, at https://pdf.usaid.gov/ pdf_docs/PA00X32Zpdf.

Sir M MacDonald \& Partners and Hunting Technical Services Ltd., 1965, East Bank Jordan water resources—Summary report: Natural Resources Authority, Amman, Jordan, 60 p., 11 plates.

\author{
For additional information, contact: \\ U.S. Geological Survey \\ Office of International Programs \\ 917 National Center \\ 12201 Sunrise Valley Drive \\ Reston, Virginia 20192 \\ directoroip@usgs.gov
}

Publishing support provided by the West Trenton and Reston Publishing Service Centers 
蛋

co

需

吾

急

电

言

要

을

旁

$\frac{5}{5}$

윢

今

్ㅗㅁ

官 